\title{
ACTANOVATIONS
}

no. 30

January 2019 
Acta Innovations

quarterly

no. 30

Konstantynów Łódzki, Poland, January 2019

ISSN 2300-5599

Original version: online journal

Online open access: www.proakademia.eu/en/acta-innovations

Articles published in this journal are peer-reviewed

Publisher:

Research and Innovation Centre Pro-Akademia

9/11 Innowacyjna Street

95-050 Konstantynów Łódzki

Poland

Editor in Chief:

Ewa Kochańska, Ph.D.

Section Editor:

Ryszard Gałczyński, Ph.D., Eng.

Scientific Secretary:

Andrzej Klimek, Ph.D., Eng.

(C) Copyright by Research and Innovation Centre Pro-Akademia, Konstantynów Łódzki 2017-2019

The tasks "Creation of the English versions of the Acta Innovations articles", "Selection \& contracting of the renowned foreign reviewers for the assessment of received manuscripts", "Acta Innovations digitalization in order to provide an open access by the Internet" and "Maintenance of the anti-plagiarism system" are financed by an agreement 605/P-DUN/2018 from the resources of Polish Ministry of Science and Higher Education dedicated to the activity popularising the science.

Zadania "Stworzenie anglojęzycznych wersji artykułów w Acta Innovations", "Dobór i kontraktacja uznanych zagranicznych recenzentów do oceny zgłaszanych manuskryptów", "Digitalizacja Acta Innovations w celu zapewnienia otwartego dostępu poprzez sieć Internet" $i$ „Utrzymanie systemu antyplagiatowego" finansowane w ramach umowy 605/P-DUN/2018 ze środków Ministra Nauki i Szkolnictwa Wyższego przeznaczonych na działalność upowszechniajq̨ą naukę. 


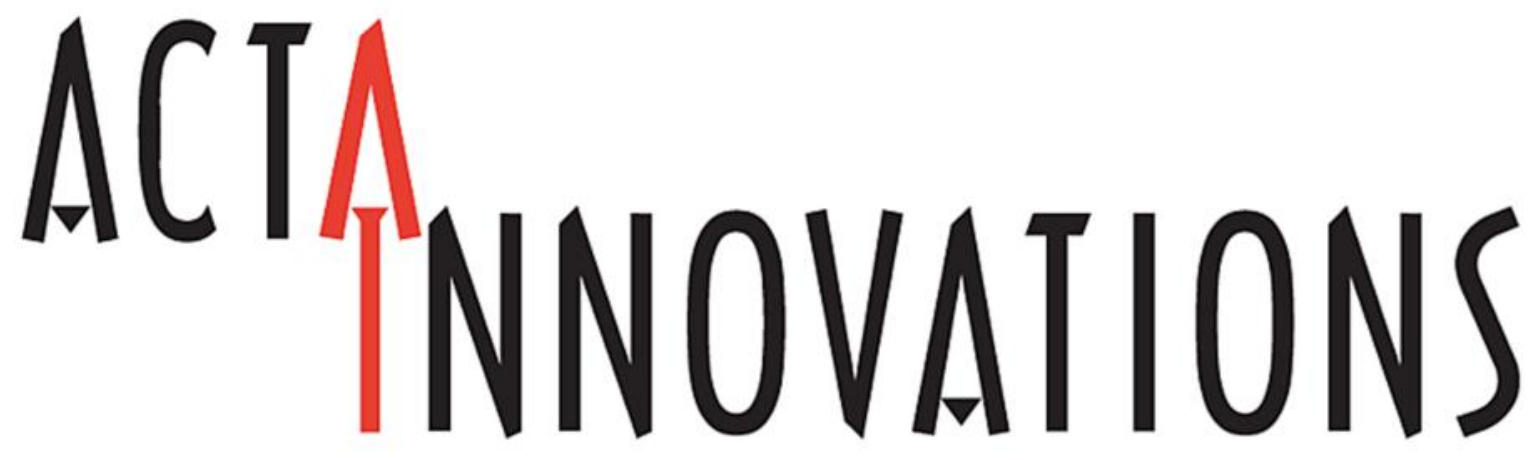

no. 30

January 2019 
Contents

Aleksandra Sosna-Głębska, Natalia Szczecińska, Katarzyna Znajdek, Maciej Sibiński REVIEW ON METALLIC OXIDE NANOPARTICLES AND THEIR APPLICATION IN OPTOELECTRONIC DEVICES

Angelika Anduła, Dariusz Heim

PRODUCTIVITY OF PV FACADES IN CHARACTERISTIC PERIODS WITH DIFFERENT ENERGY

DEMAND FOR LIGHTING 16

Monika Janas, Alicja Zawadzka

NEUTRALIZATION OF POULTRY WASTE BY THERMOHYDROLYSIS IN NEAR-CRITICAL WATER

Justyna Czerwińska, Grzegorz Wielgosiński

CHANGES IN THE POLLUTION OF LODZ VOIVODSHIP RAINWATER AS A RESULT OF CHANGES IN POLLUTANT IMMISSIONS

Marek Michalski

DEVELOPMENT OF NUCLEAR POWER AS AN ALTERNATIVE TO FOSSIL FUELS 38

Anatoliy Bogdanenko

RESEARCH ON INVESTMENT AND INNOVATION ACTIVITY IN UKRAINE: TRENDS AND PROBLEMS.

Andrii Vorfolomeiev

IMPLEMENTATION OF RESOURCE EFFICIENT AND CLEANER PRODUCTION OPTIONS AT UKRAINIAN ENTERPRISES

Anna Lewandowska

MULTIFUNCTIONALITY OF PRODUCT SYSTEMS - A GENERAL INSIGHT FROM THE CIRCULAR ECONOMY'S PERSPECTIVE.

Aleksandra Czajkowska

THE CHANGES IN THE POLISH ENERGY SECTOR TO REDUCE THE POLLUTANT EMISSIONS

IN THE ENVIRONMENT 


\title{
Aleksandra Sosna-Głębska, Natalia Szczecińska, Katarzyna Znajdek, Maciej Sibiński Department of Semiconductor and Optoelectronics Devices, Faculty of Electrical, Electronic, Computer and Control Engineering, Lodz University of Technology, Lodz, Poland \\ e-mail: alekssosnaandra@gmail.com
}

\section{REVIEW ON METALLIC OXIDE NANOPARTICLES AND THEIR APPLICATION IN OPTOELECTRONIC DEVICES}

\begin{abstract}
Among the large family of metallic oxides, there is a considerable group possessing excellent semiconducting properties. What follows, they are promising materials for applications in the field of optoelectronics and photonics. Thanks to the development of nanotechnology in the last few decades, it is now possible to manufacture a great variety of different nanostructures. By controlling their size, shape, composition and crystallinity, one can influence such properties as band gap, absorption properties, surface to volume ratio, conductivity, and, as a consequence, tune the material for the chosen application. The following article reviews the research conducted in the field of application of the metallic oxide nanoparticles, especially $\mathrm{ZnO}, \mathrm{TiO}_{2}$ and ITO (Indium-Tin Oxide), in such branches of optoelectronics as solid-state lightning, photodetectors, solar-cells and transparent conducting layers.
\end{abstract}

\section{Key words}

Metallic oxides, nanoparticles, $\mathrm{ZnO}, \mathrm{TiO}_{2}$, ITO, solar cells,

\section{Introduction regarding metallic oxides in general}

Metallic oxides (MOs) are among the most promising functional materials for several practical applications. The combination of positive metallic and negative oxygen ions, due to the high electronegativity of oxygen, results in the long-term stability of these compounds. The presence of oxygen atoms combined with metal atoms in the crystal lattice results in the formation of the bandgap in the range of $1 \div 10 \mathrm{eV}$ [1], which allows the classification of these materials as semiconductors or insulators. These values may differ with the crystallographic form of the particular oxide. Exemplary MOs with their band gap at $300 \mathrm{~K}$ are included in Fig. 1.

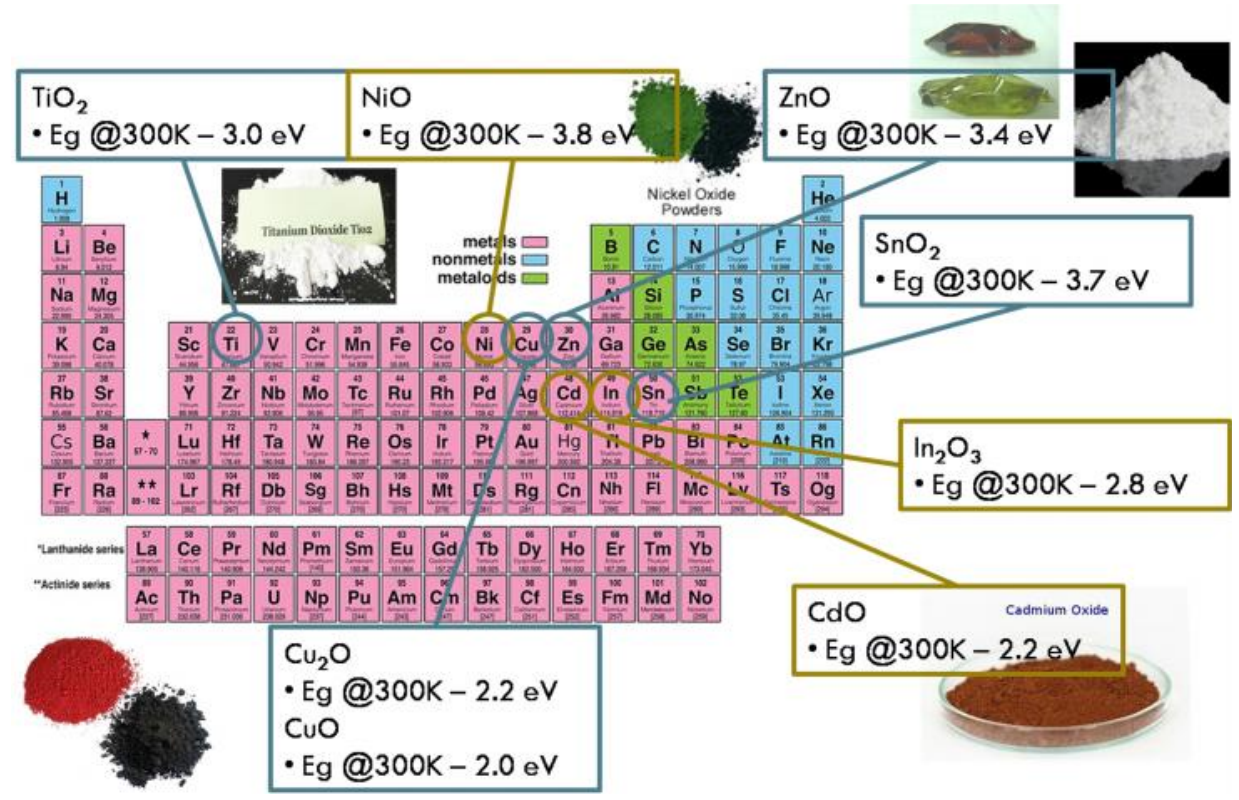

Fig. 1. Some metallic oxides which have found or may find applications in optoelectronics Source: Authors, based on Ref. [1]

Last, but not least, with the abundant mineral resources, the majority of them are not very costly and can be an environmentally-friendly alternative to a lot of toxic or rare materials. Compared to organic substance, $s$ they are more reliable and resistant to degradation due to humidity or harsh climatic conditions. 
Taking into account all those advantages, it is not surprising that MOs already fulfil an important role in our everyday life, also being a common subject of research being lead in many different scientific fields.

Currently, a common application of MOs is to use them in the form of pigments in the chemical and food industry. They can be met in the form of powders of high opacity. $\mathrm{TiO}_{2}$ and $\mathrm{ZnO}$ particularly are widely employed as a "perfect white" in paints, cosmetics and as a food colorant. Due to their band gap which corresponds to UV light, they are also used to form a UV-shielding layer, e. g in sun-protective creams, optical filters and anticorrosive coatings [2]. Due to the high thermal conductivity of $\mathrm{ZnO}$, which depends also on its form [3][4], it is a common additive to rubber which enhance the heat dissipation rate [5]. The most popular industrial application in optoelectronics is Indium Tin Oxide (ITO), used in touch screens, LCDs, solar cells etc. [6].

The range of applications under research is also very wide. As in the group of MOs, one can find those which can be either intrinsically, or by doping, p-type or n-type semiconductors, they are used in the formation of various complex architectures in electronics. A lot of the oxides have been used in the construction of thin-film transistors [7] as well as in the form of charge-injecting layers [8] and charge-transporting layers [9]. Using MOs in bulk form or in thin films, light emitting diodes [10], laser diodes, photodetectors [11] and solar cells [12] [14] are being constructed.

Apart from being semiconductors, MOs possess other interesting, exotic properties. Just to name a few: $\mathrm{ZnO}$ is characterized by a high piezoelectric constant [5] It also exhibits strong luminescence in the visible light [15], and therefore it can be used as a phosphor. $\mathrm{ZnO}$ and $\mathrm{TiO}_{2}$ exhibit strong sensitivity of surface conductivity to the presence of adsorbed molecules. They can be used as gas sensors [16]. ZnO exhibits a non-linear optical response [5] and can be used in frequency converters. $\mathrm{CuO}$ and $\mathrm{Cu}_{2} \mathrm{O}$ are known to be high-temperature superconductors [17]. $\mathrm{TiO}_{2}$ and $\mathrm{CuO} / \mathrm{Cu}_{2} \mathrm{O}$ exhibit photocatalytic properties [18]. $\mathrm{MnO}_{2}, \mathrm{HgO}, \mathrm{Ag}_{2} \mathrm{O}, \mathrm{PbO}_{2}$ are used in energy storing devices like batteries and super capacitors [19]. A lot of different applications are reviewed in [18][20][21].

\section{A few words about nanoparticles (NPs)}

Additional opportunities for engineering the properties of the above-mentioned materials are related to their miniaturisation up to the nanoscale. The advanced technology enables us to provoke a controlled growth to form such structures as thin planar films, where the movement of charge carriers is possible only in 2 directions (2-dimensional nanostructures), nanowires and nanotubes (1-dimensional nanostructures) and nanoparticles (0-dimensional structures), which, in the case when they are only several nanometers in diameter, are called quantum dots (QDs).

The miniaturisation results in t optical, electronic, thermal and chemical properties which may be quite distinct from the bulk counterpart of the nanostructure. When the size of the particle becomes of the order of several $\mathrm{nm}$, its energy structure becomes similar to an atom, which can be excited only to discrete energy levels. These possible energy levels differ with the size and shape of the particle. Thus the effective band gap of NPs increases in comparison to the bulk material, which is reflected in the blueshift of the absorption and emission spectra. This effect is known as quantum confinement and, to some extent, allows the engineering of different features of NP.

Among all types of nanostructures, there are NPs which possess the highest density of states and therefore can exhibit high luminescence efficiency of $50 \%$ or more [22]. They also possess a very narrow emission spectra, which is a desirable property in the construction of light emitting devices and also allows us to construct a sensitive detector.

NPs are characterised by a high surface area in comparison to their volume, which signifies the increasing importance of the surface atoms and the modification of the properties of the particle itself as well as when it comes into interaction with the environment. This feature makes them very attractive for the applications where surface atoms play an important role, e.g. in gas sensors [16], super capacitors [20]. Fig. 2 schematically depicts a NP. 


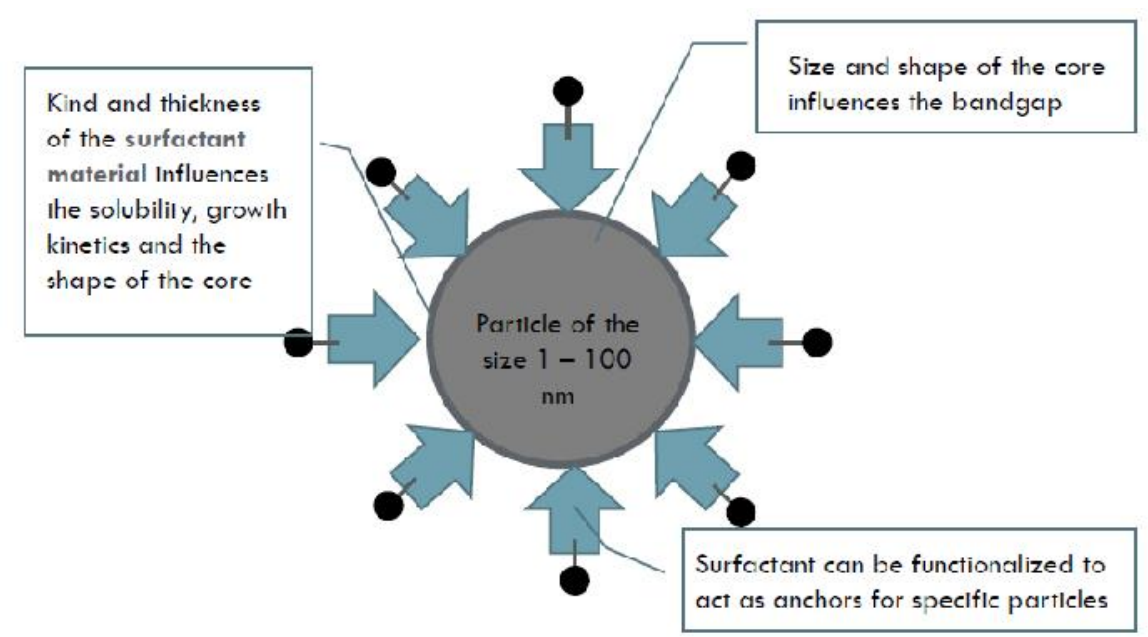

Fig. 2. Schematical view of the nanoparticle with a surfactant.

Source: Authors based on Ref. [20]

\section{Synthesis of metallic oxide nanoparticles}

There is a great variety of methods applied in order to synthesise nanoparticles. Three main subgroups can be distinguished: chemical methods, physical methods and mechanical processes such as milling. In case of MO NPs the most widely applied methods are listed below.

1. Chemical synthesis is based on precipitation of solid phase (NPs) due to the supersaturation achieved in the liquid medium composed of various reactants. The supersaturation can be achieved either by rapid cooling of a previously-heated solution or by adding the necessary reactants. Chemical synthesis can be conducted with different surfactants (which is included in Fig. 2). Surfactants enable the controlling of the structural form and size of the particle by modifying its surface tension. They also prevent particles from aggregation.

- Sol-gel method is probably the most frequent method of MO NPs synthesis. The term "sol" stands for the solution, which is composed of MO dispersed in an organic solvent. Depending on the fact if the solvent is water, the method can be specified to be aqueous or non-aqueous. The sol-gel transformation consists of reactions of hydrolysis, condensation and polymerisation. As the hydroxide polymerises, a dense porous three-dimensional gel is obtained. Subjecting it to subsequent drying and heating, the final form of the oxide can be controlled which could be coatings, solid foam, fibres, nanoparticles etc. as depicted in the Fig. 3.

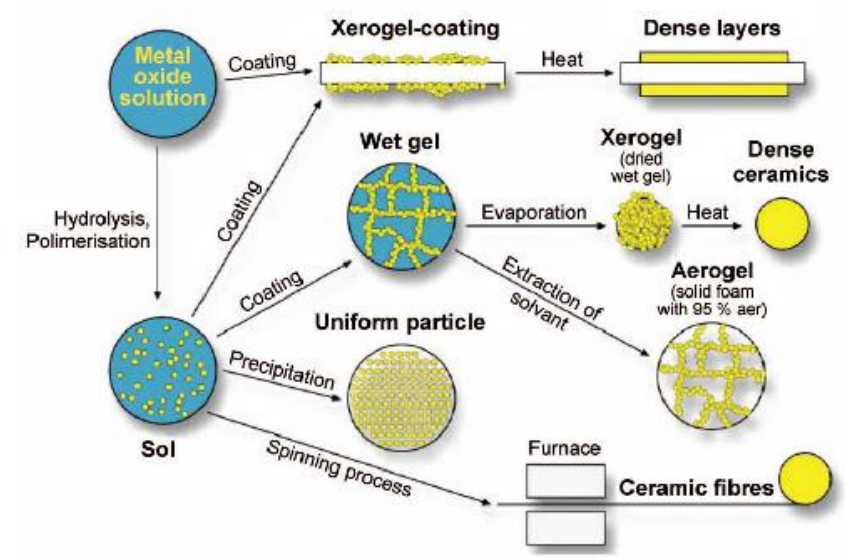

Fig. 3. Diagram of the sol-gel process.

Source: Universität Ulm, Anorganische Chemie

The pictures taken with the transmission electron-microscope (TEM) of different types of metal oxide nanoparticles synthesized by non-aqueous sol-gel method are depicted in the Fig. 4. 


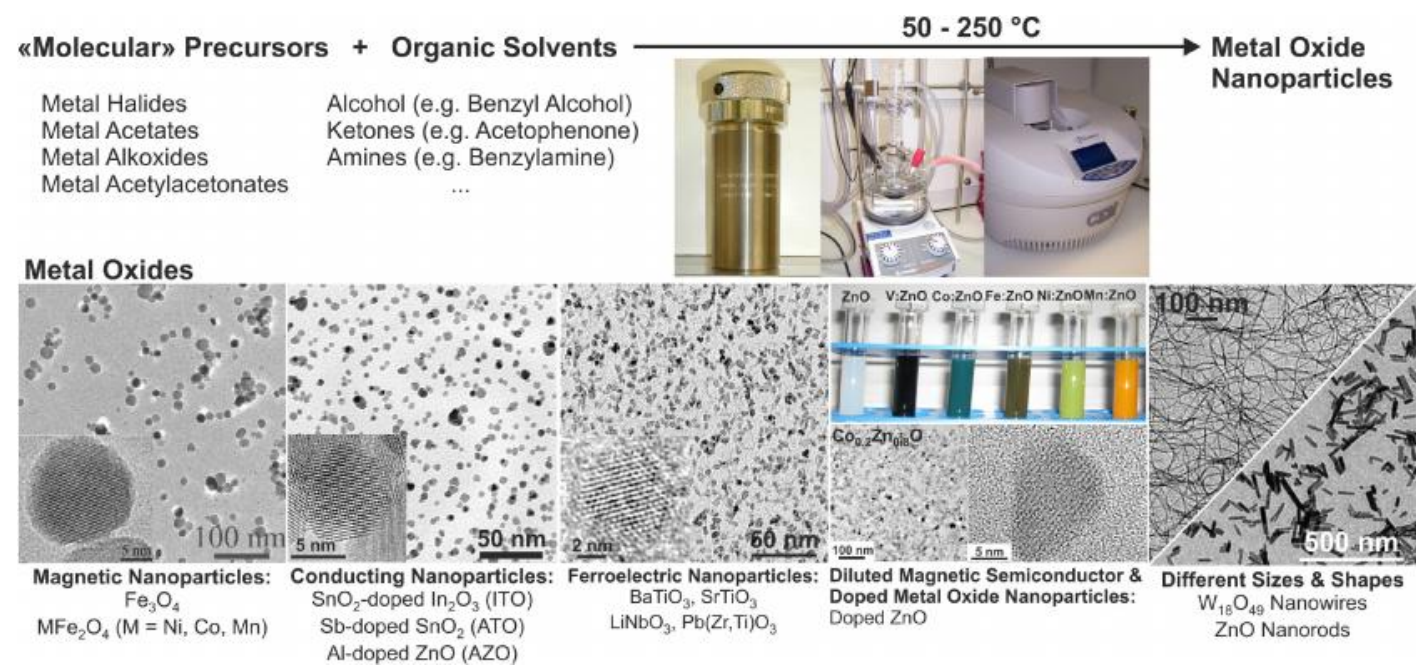

Fig. 4. Upper part: schematic of the non-aqueous and surfactant-free liquid-phase synthesis approach to MO NPs using autoclave, oil bath or microwave heating. Lower part: TEM images of selected MO NPs synthesized by the non-aqueous solgel approach.

Source: [24]

- Solvothermal synthesis employs dispersing the starting material in the solvent (if the solvent is water the name of the method becomes "hydrothermal synthesis") and subjecting it to high temperature and pressure, which results in supersaturation followed by the nucleation growth of particles. The particle size and shape can be controlled by the chemical parameters of the reaction - kind and ratio of the reactants, and thermodynamic parameters - temperature, pressure, time [23].

2. Physical methods of synthesis essentially incorporate a decomposition of a solid precursor into molecules or even single atoms, which are than deposited in the desirable form of a nanostructure. Usually these types of methods are the costliest as they require expensive vacuum techniques and the deposited layer area is strictly limited by the chamber dimensions. There is a great variety of physical deposition methods, among which those successfully applied in the generation of MO NPs are:

- Physical Vapour Synthesis (PVS) involves a plasma arc applied to a solid target in order to generate vapour and trigger reactions leading to supersaturation. Mixing the resultant atoms with the reactive gas and cooling down results in the formation of molecular clusters which then aggregate in the form of particles [26]. In this method, the parameters of the particles are controlled by the type of the reactant gas and cooling rate [27]. A form of this method when the supersaturated gas additionally is subjected to the supersonic adiabatic expansion is called low energy cluster beam deposition (LECBD) and is applied in the formation of e.g. ZnO NPs [28].

- Pulsed laser ablation method uses a high-power laser beam to vaporise the atoms from the solid target. The process can be conducted in ultrahigh vacuum (in this case the target is a bulk metal oxide) or in the presence of a background gas like oxygen. In the latter case the target can be made out of pure metal and its oxidation happens during the deposition

3. Mechanical methods are the top-down approach in the production of nanostructures. Those based on milling of bulk MOs are often used in pigment manufacturing and the ink industry in order to achieve a fine grinding and uniform dispersion of particles in the pigment. The dimensions of particles achieved are of no smaller than $200-300 \mathrm{~nm}$ [20]. Although there is a mechanical method successfully applied in the creation of MO NPs of smaller sizes, namely mechanochemical processing.

- Mechanochemical processing (MCP) is a synthesis method which combines a reduction of physical size in a ball-mill and chemical reaction, activated at the nanoscale during grinding [26]. The precursors collide in the ball mill in the presence of the proper diluent and an exchange reaction takes place. Often a heat treatment is applied for the further decomposition of the compound which comes into being (e.g. ZnCO3 obtained during synthesis decomposes to $\mathrm{ZnO}$ when heated). With this method, NPs of the size in the range $18 \div 40 \mathrm{~nm}$ have been produced, depending on the milling time and the 
temperature at which the heat treatment takes place [29]. This method can be applied for the generation of MO NPs of those oxides for which the suitable precursors can be found.

Table 1: Summary of the revised fabrication method with the type of synthesized MO and the NPs size.

\begin{tabular}{|c|c|c|c|}
\hline & Method & Type of MO synthesized & NPS size \\
\hline \multirow[t]{3}{*}{ Chemical } & Sol-gel & $\begin{array}{c}\mathrm{TiO}_{2}, \mathrm{ZnO}, \mathrm{MgO}, \mathrm{CuO}, \mathrm{ZrO}_{2}[23] \\
\mathrm{SnO}_{2} \text { and many others }\end{array}$ & $>20 \mathrm{~nm}[30]$ \\
\hline & Solvothermal Synthesis & $\begin{array}{c}\mathrm{MgO}, \mathrm{TiO}_{2}, \mathrm{Fe}_{3} \mathrm{O}_{4}, \mathrm{WO}_{x}[25], \text { and } \\
\text { many others }\end{array}$ & $\begin{array}{l}\text { Ultra small, single } \mathrm{nm} \\
{[25]}\end{array}$ \\
\hline & Mechanochemical processing & $\mathrm{ZnO}[29]$ & $18 \div 40 \mathrm{~nm}[29]$. \\
\hline \multirow[t]{2}{*}{ Mechanical } & & & \\
\hline & Milling & all & $\begin{array}{l}\text { Larger than } 200-300 \\
\text { nm [20] }\end{array}$ \\
\hline \multirow[t]{2}{*}{ Physical } & Physical Vapour Synthesis & $\mathrm{ZnO}[28]$ & $\begin{array}{c}\text { Av. size }-8 \text { to } 75 \mathrm{~nm} \\
\text { [27]. }\end{array}$ \\
\hline & Pulsed Laser Ablation & $\begin{array}{c}\mathrm{V}_{2} \mathrm{O}_{5}, \mathrm{WO}_{3}, \mathrm{ZnO}, \mathrm{SnO}_{2}[31], \mathrm{NiO} \\
\mathrm{ZrO}_{2}, \mathrm{Cu} / \mathrm{Cu}_{2} \mathrm{O}[23] \text { and many } \\
\text { others }\end{array}$ & Av. Size - $20 \mathrm{~nm}[31]$ \\
\hline
\end{tabular}

Source: Authors'

A great advantage of NPs is the fact that they can be dispersed in a chosen matrix - e.g. polymer. They can be used to form inks, pastes and gels which can be easily deposited with non-costly techniques suitable for both small scale deposition laboratory techniques like spin coating and dip coating, as well as large scale thin film deposition methods like spray-coating, roll-to-roll printing or doctor-blading [32]. This feature opens a great variety of applications in thin film and flexible electronics [21].

\section{Applications in optoelectronics}

This section presents the state-of-the-art in the application of some of the MO NPs, whose properties and fabrication techniques has been previously considered (Figure 1, Table 1).

\section{- $\quad$ Applications in light emitting devices}

As nanoparticles are prone to have high luminescence quantum yield they can be possibly applied in the light emitting devices. They should also possess a direct band gap to emit light in the limited and desired spectral range. The exemplary constructions of the devices based on nanoparticles are depicted in Fig. 5.

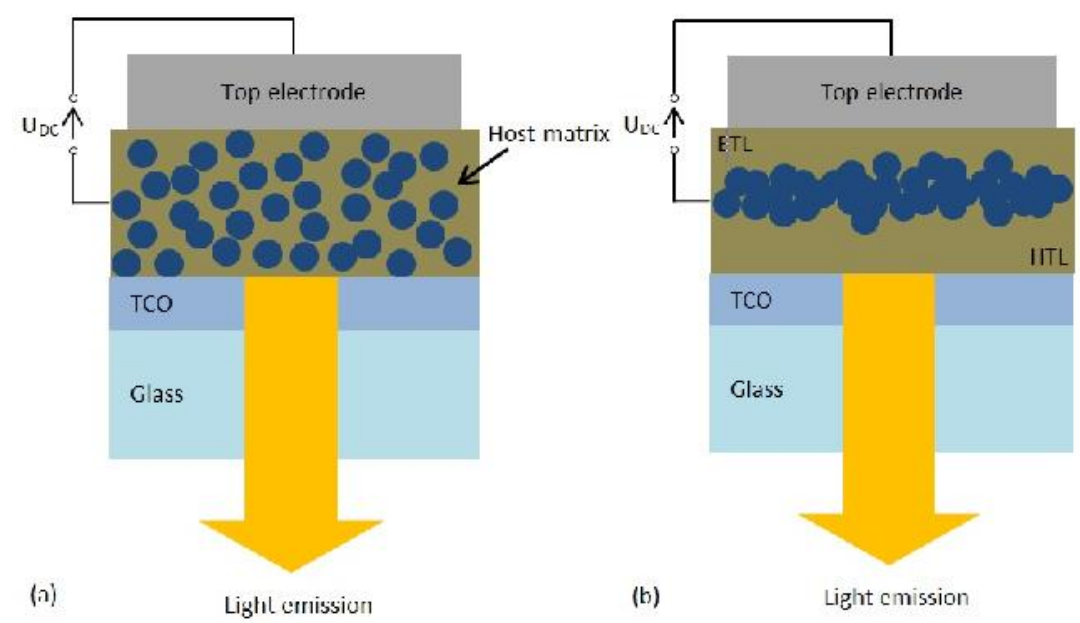

Fig. 5. Different concepts of NPs-based DC LEDs with transparent conducting oxide (TCO) as an anode and a metallic top electrode as a cathode, and a DC voltage applied across them. In the design a) the NPs are dispersed in an organic host matrix whereas in the design b) the light-emitting NPs are assembled in a tight layer neighbouring with hole- and electron transporting layer (HTL and ETL respectively).

Source: Authors based on Ref. [20] 
The concept of LED depicted in Fig. 5, a) was successfully realised for the first time in 1994 with CdSe QDs [33]. The efficiency of this device was low $-0.01 \%$, but a lot of devices of similar structure, based on NPs have been developed since then.

Among the group of MOs it is $\mathrm{ZnO}$ that fulfils the condition for light emitting deivce (direct band gap), which is above $3 \mathrm{eV}$ at room temperature [5]. Natural defects in $\mathrm{ZnO}$ particles, like oxygen vacancies or $\mathrm{Zn}$ interstitials, as well as doping with metal atoms, can result in additional energy states within the bandgap and the emission of different wavelengths in the visible range becomes possible [15]. In the case of defect-related emission, the emitted colour is not connected to the size of the particles. Thus crystals of the sizes larger than $100 \mathrm{~nm}$ can be used which decreases the manufacturing cost. A ZnO nanoparticle-based light-emitting diode has been constructed by Neshataeva et al. [34]. In this design the $\mathrm{ZnO}$ nanoparticles were sandwiched between transparent electrodes made of Fluorine doped Tin Oxide (FTO) and a layer of Al acting as a cathode (Fig. 6a). The defect-related electroluminescence has been observed - Fig. 6b, with the spectral range covering red and NIR wavelengths for lower bias values like $4 \mathrm{~V}$ with a spectrum shifting towards the lower wavelengths when a larger bias - $10 \mathrm{~V}$ - has been applied. Such a spectrum resulted in the emission of white light.
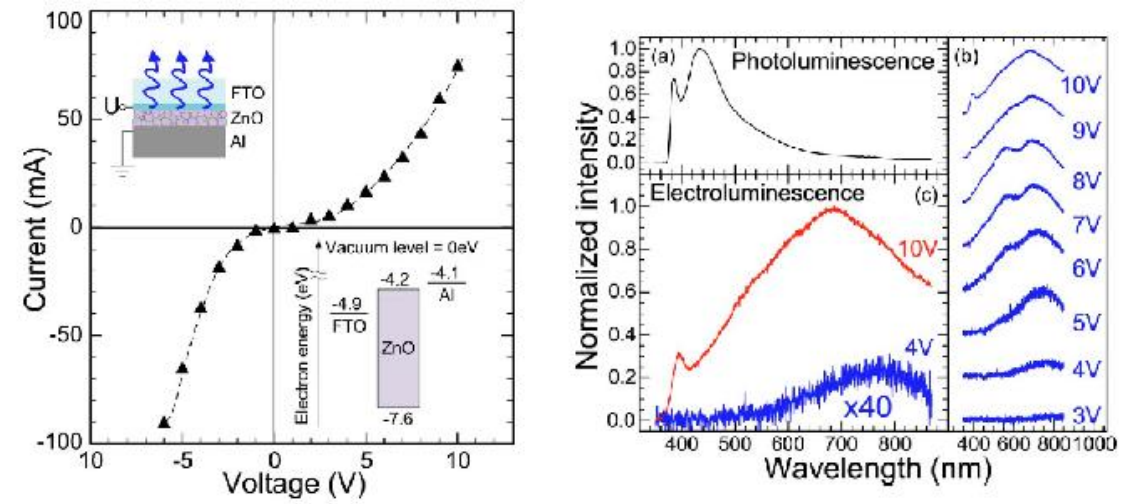

Fig. 6. a) Room temperature I-V characteristics of the light-emitting device based on $\mathrm{ZnO}$ nanoparticles and its b) $334.5 \mathrm{~nm}$ excited PL spectrum and EL spectra of the device biased in the forward direction. Source:[34]

Another approach in creating a white light emitting device is taking advantage of the photoluminescence effect of the $\mathrm{ZnO}$ nanoparticles. A stack of different phosphor layers emitting in red, green and blue excited by UV or blue light is one of the concepts for the creation of white LED [35].

$\mathrm{ZnO}$ as well is considered an alternative to $\mathrm{GaN}$, as creating only blue or UV emitting diode from $\mathrm{ZnO}$ is theoretically possible, but has not been proved experimentally [20].

- MO NPs as Charge Transporting Layers

MOs have been used both in the form of bulk and nanostructured materials for the formation of charge transporting layers (CTL) (they are included in the scheme depicted in Fig. 5, b). This allows the formation of organic-free LED, which is highly desirable as organic substances tend to rapidly deteriorate when exposed to humidity or oxygen [34] and also enables the use of much higher current densities [21]. In literature, one can find the applications of $\mathrm{CuO}$ as the hole transporting layer ( $\mathrm{HTL}$ ) [36], nanoparticles of $\mathrm{ZrO}_{2}$ as the electron transporting layer (ETL) [37], QD LED with $\mathrm{MoO}_{3}$ used as an $\mathrm{HTL}$ and $\mathrm{TiO}_{2}$ used as an ETL [38], ZnO as the ETL [1]. These layers have been used in the construction of light emitting devices, photodetectors and solar cells. Especially in organic dye sensitized solar cells (DSSC) a very important role is fulfilled by $\mathrm{TiO}_{2}$, which serves as a charge transporting layer and the area of which is used for the absorption of dye. The mesoporous structure of titania, which can be achieved e.g. by sintering $\mathrm{TiO}_{2}$ NPs, provides $\sim 100$-fold enhancement of the surface area per micrometer of thickness in comparison to the flat film [20]. A larger active area leads to high-density packed monolayer of the dye and the enhancement of the light harvesting properties of the solar cell. 
- MO NPs as light-converting medium

The photoluminescence effect of NPs can be also used to create a light converting layer. It may find application e.g. in photovoltaics as the conventional homojunction solar cells are not able to use the whole solar spectrum with UV and NIR being particularly problematic. ZnO NPs have been proposed as down-converting (DC) agents, which are able to absorb the UV light and then re-emit it in the visible range [39] - [41]. Doping or mixing them with rare earth elements (REE) [42] can prolong the luminescence time and efficiency. MO NPs have been also applied in the up-conversion (UC) process [43], in which low energy photons from near infrared are absorbed in order to obtain the emission of the photons from the visible range. For this application the MO NPS of e.g.. $\mathrm{ZnO}, \mathrm{ZrO}_{2}, \mathrm{Y}_{2} \mathrm{O}_{3}, \mathrm{Lu}_{2} \mathrm{O}_{3}$, $\mathrm{BaTiO}_{3}, \mathrm{TiO}_{2}$ [15] have been used as a host matrix for such REE as $\mathrm{Er}, \mathrm{Ho}, \mathrm{Nd}, \mathrm{Yb}$ [44].

The photoluminescence effect of NPs can be also used for the fabrication of luminescent converters [45], which is one of the forms of geometric concentration of sunlight reaching the photovoltaic cell. The operation principle is explained in the Fig. 7.

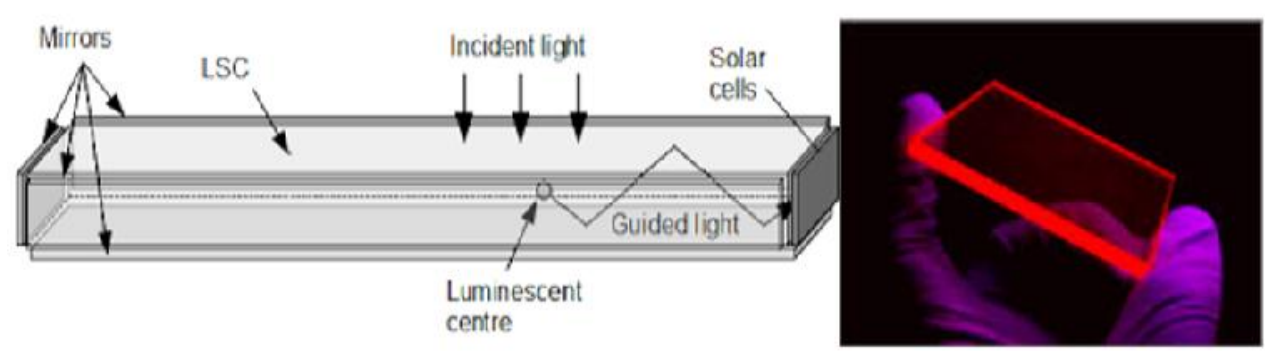

Fig. 7. Schematic picture of a luminescent concentrator. NPs act as luminescent centers, they absorb the incident light and emit the light in different frequency. Total internal reflection traps the emitted photons in the concentrator and guides the light towards the solar cells on the edges. Part of the light striking the internal surface at very steep angles manages to escape the structure through escape cone of total internal reflection.

Source: [46].

- Applications as transparent conducting oxides (TCO)

The general electro-optical requirements for the transparent conductor is the resistivity of the order of $10^{-3} \mathrm{~cm}$ or less, and the average transmittance above $80 \%$ in the visible range. Therefore, a semiconductor material suitable for this application should have a carrier concentration at least $10^{20}$ $\mathrm{cm}^{-3}$ and an energy band gap above $3.0 \mathrm{eV}$ [47]. An important group of MOs possesses these properties, the most popular studied materials and their dopants are gathered in Table 2.

Table 2: Most popular TCO materials and their dopants.

\begin{tabular}{|c|c|c|}
\hline & Material & Dopant or compound \\
\hline & $\mathrm{SnO}_{2}$ & $\mathrm{Sb}, \mathrm{F}, \mathrm{As}, \mathrm{Nb}, \mathrm{Ta}$ \\
\hline & $\ln _{2} \mathrm{O}_{3}$ & $\mathrm{Sn}$ (ITO), Ge, Mo, F, Ti, Zr, Hf, Nb, Ta, W, Te \\
\hline & $\mathrm{ZnO}$ & Defect-controlled doping, Al (AZO), Ga (GZO) \\
\hline & $\mathrm{CdO}$ & In, Sn \\
\hline & $\mathrm{TiO}_{2}$ & $\mathrm{Ag}, \mathrm{Nb}$ \\
\hline \multirow{6}{*}{ Binary oxides } & $\mathrm{ZnO}-\mathrm{SnO}_{2}$ & $\mathrm{Zn}_{2} \mathrm{SnO}_{4}, \mathrm{ZnSnO}_{3}$ \\
\hline & $\mathrm{ZnO}-\ln _{2} \mathrm{O}_{3}$ & $\mathrm{Zn}_{2} \mathrm{In}_{2} \mathrm{O}_{5}, \mathrm{Zn}_{3} \mathrm{In}_{2} \mathrm{O}_{6}$ \\
\hline & $\mathrm{CdO}-\mathrm{SnO}_{2}$ & $\mathrm{Cd}_{2} \mathrm{SnO}_{4}, \mathrm{CdSnO}_{3}$ \\
\hline & $\mathrm{CdO}-\mathrm{In}_{2} \mathrm{O}_{3}$ & $\mathrm{Cdln}_{2} \mathrm{O}_{4}$ \\
\hline & $\mathrm{MgIn}{ }_{2} \mathrm{O}_{4}$ & \\
\hline & $\mathrm{GaInO}_{3}$ & \\
\hline \multirow{2}{*}{ Ternary oxides } & $\mathrm{ZnO}-\mathrm{In}_{2} \mathrm{O}_{3}-\mathrm{SnO}_{2}$ & $\mathrm{Zn}_{2} \mathrm{In}_{2} \mathrm{O}_{5}-\ln _{4} \mathrm{Sn}_{3} \mathrm{O}_{12}$ \\
\hline & $\mathrm{CdO}-\mathrm{In}_{2} \mathrm{O}_{3}-\mathrm{SnO}_{2}$ & $\mathrm{Cdln}_{2} \mathrm{O}_{4}-\mathrm{Cd}_{2} \mathrm{SnO}_{4}$ \\
\hline $\begin{array}{c}\text { Quarternary } \\
\text { oxides }\end{array}$ & $\mathrm{ZnO}-\mathrm{CdO}-\mathrm{In}_{2} \mathrm{O}_{3}-\mathrm{SnO}_{2}$ & \\
\hline
\end{tabular}

Source: Authors', based on [46]. 
Currently, the most widely used transparent conductor is Indium-Tin Oxide (ITO). It has been found that the 90/10 atomic ratio of $\ln _{2} \mathrm{O}_{3}$ to $\mathrm{SnO}_{2}$ results in the optimal electro-optic properties [6]. However, this material possesses some disadvantages, namely its brittleness - it can fracture at relatively low strains of $2-3 \%$ which causes an increase in resistivity [48] [49], and scarcity of supply indium is a fairly rare material and current demand for ITO consumes about $3 / 4$ of global indium consumption and is constantly rising [6].

Among other materials studied, especially interesting and environmentally friendly materials is $\mathrm{ZnO}$ and its Al and Ga-doped versions, commonly named AZO [50] and GZO respectively. Recent advances in the deposition methods of such thin films have allowed the achievement of comparable results in terms of resistivity as for ITO [47].

A solution for the inconveniences of the ITO bulk electrode is manufacturing a printing paste containing ITO NPs dispersed in a solvent and depositing it on the polymer flexible substrate [51].It has been proved that UV treatment and annealing under various atmospheres enables the achievement of a resistivity of $0.035 \Omega \mathrm{cm}$ with $89 \%$ optical total transmittance electro-optic properties [52] are sufficiently satisfying to apply the NP layer as a contact $f$. e. in organic photodiodes. What is more, such geometry of electrodes (conducting NPs dispersed in a nonconducting host matrix) results in a higher charge-transfer surface than a plain electrode and highly increases the electrode kinetics [54]. This concept has also been applied to different types of MOs e.g. the ZnO NPs for the inter-electrode in tandem organic cell [55].

\section{Summary and conclusions}

In the frame of the following review, the general properties of MO and NPs have been described, as well as some applications of MO NPs in optoelectronics have been enumerated. It should be taken into account that they are only the tip of an iceberg already in the field of optoelectronics, not to mention other domains. In some fields MO NPs are already the leading solution like in the field of transparent electrodes. Some of the similar features are possessed by carbon nanostructures and advanced polymers [6], which achieve approximate, but still inferior, parameters. Although for the majority of optoelectronic applications the MO NPs are being extensively researched as an alternative material to some of the rare and costly semiconductors. An noticeable trend in electronics is the gradual shift from all-inorganic and Si-centered devices towards hybrid flexible and lightweight organic-inorganic devices. The MO NPs seem to be a suitable candidate, but there are still some obstacles before commercializing the practical application of them. Either an effort should be made in order to increase the effectiveness of the prototype devices or the stress should be put to lower the cost of the manufacturing and deposition techniques.

\section{References}

[1] Portier, J. et al., Thermodynamic correlations and band gap calculations in metal oxides (2004) Progress in Solid State Chemistry, 32 (3-4), pp. 207-217

[2] Pugazhenthi, I. et al., UV and corrosion protective behavior of polymer hybrid coating on mild steel, 2018) Journal of Applied Polymer Science, 135 (16), art. no. 46175

[3] Wang, H. et al., Low thermal conductivity of monolayer $\mathrm{ZnO}$ and its anomalous temperature dependence, (2017), Physical Chemistry Chemical Physics, 19, pp. 12882-12889

[4] Pandiyarasan, V. et al., Morphology dependent thermal conductivity of ZnO nanostructures prepared via a green approach, (2017), Journal of alloys and compounds, 695, pp. 888-894

[5] Janotti, A. et al., Fundamentals of zinc oxide as a semiconductor, (2009) Reports on Progress in Physics, 72 (12), art. no. 126501

[6] Hecht, D.S. et al., Emerging transparent electrodes based on thin films of carbon nanotubes, graphene, and metallic nanostructures,(2011) Advanced Materials, 23 (13), pp. 1482-1513 
[7] Fortunato, E. et al, Oxide semiconductor thin-film transistors: A review of recent advances,(2012) Advanced Materials, 24 (22), pp. 2945-2986

[8] Meyer, J. et al., Transition metal oxides for organic electronics: Energetics, device physics and applications, (2012) Advanced Materials, 24 (40), pp. 5408-5427

[9] Ramanathan, K. et al., Properties of $19.2 \%$ efficiency ZnO/CdS/CulnGaSe2 thin-film solar cells, (2003) Progress in Photovoltaics: Research and Applications, 11 (4), pp. 225-230.

[10]Tsukazaki, A. et al., Repeated temperature modulation epitaxy for p-type doping and lightemitting diode based on ZnO (2005) Nature Materials, 4 (1), pp. 42-45

[11]Jagadish, C. et al., Zinc Oxide Bulk, Thin Films and Nanostructures, (2006) Zinc Oxide Bulk, Thin Films and Nanostructures, Elsevier Science

[12] Wong, T.K.S. et al., Current status and future prospects of copper oxide heterojunction solar cells, (2016) Materials, 9 (4), art. no. 271

[13] Tsai T. Y. et al., P-Cu2O-shell/n-TiO2-nanowire-core heterostructure photodiodes, (2011) Nanoscale Res Lett 6:575, pp. 1-7

[14] Bai, Y. et al., Titanium dioxide nanomaterials for photovoltaic applications, (2014) Chemical Reviews, 114 (19), pp. 10095-10130

[15] Vinod Kumar et al., Rare Earth Doped Zinc Oxide Nanophosphor Powder: A Future Material for Solid State Lighting and Solar Cells, ACS Photonics 20174 (11), pp. 2613-2637

[16] Comini, E. Metal oxide nano-crystals for gas sensing (2006) Analytica Chimica Acta, 568 (1-2), pp. 2840

[17] Tranquada, J.M. et al., Evidence for stripe correlations of spins and holes in copper oxide superconductors, (1995) Nature, 375 (6532), pp. 561-563

[18] Diao F. et al., Transition metal oxide nanostructures: premeditated fabrication and applications in electronic and photonic devices (2018) Journal of Materials Science, 53 (6), pp. 4334-4359

[19]Zhu S.J. et al., Rational design of octahedron and nanowire CeO2@MnO2 core-shell heterostructures with outstanding rate capability for asymmetric supercapacitors (2015), Chem Commun 51, pp. 14840-14843

[20] Altavilla, C. (Ed.), Ciliberto, E. (Ed.). (2011). Inorganic Nanoparticles. Boca Raton: CRC Press

[21] Litvin, A.P. et al., Colloidal quantum dots for optoelectronics (2017) Journal of Materials Chemistry A, 5 (26), pp. 13252-13275

[22] Alivisatos, A.P., Semiconductor clusters, nanocrystals, and quantum dots, (1996) Science, 271 (5251), pp. 933-937

[23] Stankic, S. et al., Pure and multi metal oxide nanoparticles: Synthesis, antibacterial and cytotoxic properties,(2016) Journal of Nanobiotechnology, 14 (1), art. no. 73

[24] Heiligtag, F.J. et al, The fascinating world of nanoparticle research,(2013) Materials Today, 16 (78), pp. 262-271 
[25] Ren, Y. et al., Nanoparticulate TiO 2(B): An anode for lithium-ion batteries, (2012) Angewandte Chemie - International Edition, 51 (9), pp. 2164-2167

[26] Espitia, P.J.P. et al., Zinc Oxide Nanoparticles: Synthesis, Antimicrobial Activity and Food Packaging Applications, (2012) Food and Bioprocess Technology, 5 (5), pp. 1447-1464

[27] Casey, P., Nanoparticle technologies and applications,(2006) Nanostructure Control of Materials, pp. 1-31

[28] A. Apostoluk et al., Efficient ultraviolet light frequency down-shifting by a thin film of $\mathrm{ZnO}$ nanoparticles, International Journal of Nanotechnology 11 (2012), pp. 1240022-1-1240022-5

[29] Aghababazadeh, R. et al., ZnO Nanoparticles Synthesised by mechanochemical processing, (2006) Journal of Physics: Conference Series, 26 (1), pp. 312-314

[30]Thiagarajan, S. et al., Facile Methodology of Sol-Gel Synthesis for Metal Oxide Nanostructures, (2017), Recent Appl. Sol-Gel Synth., pp. 1-16

[31] Huotari, J. et al., Pulsed Laser Deposition of Metal Oxide Nanoparticles, Agglomerates, and Nanotrees for Chemical Sensors, (2015), Procedia Engineering, 120, pp. 1158-1161

[32] A. Maulu, P. J. et al., Strongly-coupled PbS QD solids by Doctor Blading for IR Photodetection, RSC Adv., 2016, 6, pp. 80201-80212

[33] Colvin, V.L. et al., Light-emitting diodes made from cadmium selenide nanocrystals and a semiconducting polymer, (1994) Nature, 370 (6488), pp. 354-357.

[34] Neshataeva, E. et al., All-inorganic light emitting device based on ZnO nanoparticles, (2009) Applied Physics Letters, 94 (9), art. no. 091115

[35] Steigerwald, D.A. et al., Illumination with solid state lighting technology (2002) IEEE Journal on Selected Topics in Quantum Electronics, 8 (2), pp. 310-320

[36] Tao Ding et al., Colloidal quantum-dot LEDs with a solution-processed copper oxide (CuO) hole injection layer, Organic Electronics, Volume 26, 2015, pp. 245-250

[37] Kim, H. Y. et al., Transparent InP Quantum Dot Light-Emitting Diodes with $\mathrm{ZrO}_{2}$ Electron Transport Layer and Indium Zinc Oxide Top Electrode, (2016) Adv. Funct. Mater., 26, pp. 3454-3461

[38] Y.-J. Kwack et al., Solution-Processed Quantum Dot LEDs Using Molybdenum Oxide and Titanium Oxide as Charge Transport Layers, J. Nanoelectron. Optoelectron., 2016, 11, pp. 234-238

[39] Apostoluk, A. et al., Investigation of luminescent properties of $\mathrm{ZnO}$ nanoparticles for their use as a down-shifting layer on solar cells (2013) Physica Status Solidi (C) Current Topics in Solid State Physics, 10 (10), pp. 1301-1307

[40] Apostoluk A. et al., "Improvement of the solar cell efficiency by the ZnO nanoparticle layer via the down-shifting effect" Microelectronic Engineering Volume 127, 5 September 2014, pp. 51-56

[41] Znajdek K. et al., Zinc oxide nanoparticles for improvement of thin film photovoltaic structures' efficiency through down shifting conversion (2017) Opto-electronics Review, 25 (2), pp. 99-102

[42] Znajdek $\mathrm{K}$ et al., Luminescent layers based on rare earth elements for thin-film flexible solar cells applications, Optik - International Journal for Light and Electron Optics 165 (2018), pp. 200-209 
[43] Trupke, T. et a., Improving solar cell efficiencies by up-conversion of sub-band-gap light. J. Appl. Phys., 92 (7) (2002), pp. 4117-4122

[44] Das, R. et al., Dual Mode Luminescence in Rare Earth (Er3+/Ho3+) Doped ZnO Nanoparticles Fabricated by Inclusive Coprecipitation Technique. J. Mater. Sci.: Mater. Electron. 2015, 26, pp. 7174-7182

[45] Goldschmidt, J.C. et al., Fluorescent Concentrators for Photovoltaic Applications (2015) in Photon Management in Solar Cells, Wiley VCH

[46] Lo Chin Kim, et. al. "A New Hybrid Algorithm Using Thermodynamic and Backward Ray-Tracing Approaches for Modeling Luminescent Solar Concentrators" December 2010, doi: 10.3390/en3121831

[47] Minami, T., Transparent conducting oxide semiconductors for transparent electrodes, (2005) Semiconductor Science and Technology, 20 (4), pp. S35-S44

[48] Cairns, D.R. et al., Strain-dependent electrical resistance of tin-doped indium oxide on polymer substrates, (2000) Applied Physics Letters, 76 (11), pp. 1425-1427

[49] Sibiński, M. et al., Degradation of flexible thin-film solar cells due to a mechanical strain (2017) Opto-electronics Review, 25 (1), pp. 33-36

[50]Sibiński, M. et al., AZO layers deposited by PLD method as flexible transparent emitter electrodes for solar cells (2014) Microelectronic Engineering, 127, pp. 57-60

[51] Sibiński, M. et al., Comparison of ZnO:Al, ITO and carbon nanotube transparent conductive layers in flexible solar cells applications (2012) Materials Science and Engineering B: Solid-State Materials for Advanced Technology, 177 (15), pp. 1292-1298

[52] Ederth, J. et al., Thin porous indium tin oxide nanoparticle films: Effects of annealing in vacuum and air (2005) Applied Physics A: Materials Science and Processing, 81 (7), pp. 1363-1368

[53]Heusing, S. et al., Wet chemical deposited ITO coatings on flexible substrates for organic photodiodes,(2009) Thin Solid Films, 518 (4), pp. 1164-1169

[54] Ward, K.R. . et al.,Nanoparticle modified electrodes can show an apparent increase in electrode kinetics due solely to altered surface geometry: The effective electrochemical rate constant for nonflat and non-uniform electrode surfaces (2013) Journal of Electroanalytical Chemistry, 695, pp. 1-9

[55] Lee, D. et al., Transparent electrode with ZnO nanoparticles in tandem organic solar cells, (2011) Solar Energy Materials and Solar Cells, 95 (1), pp. 365-368. 


\title{
Angelika Anduła, Dariusz Heim \\ Lodz University of Technology, Faculty of Process and Environmental Engineering \\ Wólczańska 213, 90-924 Łódź, Poland, angelika.andula@wp.pl
}

\section{PRODUCTIVITY OF PV FACADES IN CHARACTERISTIC PERIODS WITH DIFFERENT ENERGY DEMAND FOR LIGHTING}

\begin{abstract}
This paper presents an analysis of the possibilities of using energy generated by an experimental photovoltaic façade located on the building of the Technical University of Lodz, on the eastern elevation. The energy produced by the façade was designed to cover the demand for lighting in an office room. Research was carried out during the years 2015 - 2017 in selected periods of the year. The analysis showed that the winter and transitional periods generated much less electricity compared to the summer period, which is inversely proportional to the energy demand for artificial lighting in the office room.
\end{abstract}

\section{Key words}

built-in lighting, electricity, office room, photovoltaic façade

\section{Introduction}

More and more frequently, at the design stage of construction works, it is assumed that renewable energy sources are used in a given facility, which are intended to help cover energy needs as much as possible. This is mainly due to the growing interest in alternative energy sources that have a better impact on the environment than the conventional sources used up until now, based mainly on the consumption of fossil fuels. Political and social pressures focused on environmental protection and the broadly understood sustainable development have a great impact on this [1]. In this respect, photovoltaic installations (PV) are very popular. They are characterized by the possibility of using solar energy to produce electricity as a result of photoelectric conversion [2]. New technologies allow not only for the installation of photovoltaic systems in the form of additional construction on existing building elements, the so-called BAPV (Building Applied Photovoltaic). The creation of systems directly integrated with the façade of the building is also becoming more and more popular, the so-called BIPV (Building Integrated Photovoltaic). In this case, photovoltaic elements are used as components of traditional building components - they can act as a roof, façade, balustrade or shading. This solution is advantageous both for residential and commercial buildings, for example in the case of high office buildings. In addition, it is also worth bearing in mind that in favour of photovoltaic cells it is supported by the fact that they can be mounted not only on the building level, but also at an angle as a shading overhang and on flat and sloping roofs. An additional advantage is also the fact that PV panels mounted at an angle on the wall of the building will generate higher energy gains than in the case of horizontal or vertical installations, which results from a better angle of incidence of solar radiation [3].

In order to achieve the most profits, it is necessary, at the design stage, to determine the best location for panels on a given building, taking into account the most favourable orientation as well as the inclination angle, thanks to which the sun will be at the best possible level [4]. Another important factor, especially in the case of commercial facilities, is the inclusion of working hours in such a facility, because it is during their time that the largest consumption of electricity for various needs takes place [5].

The article refers specifically to the office building, because such buildings are characterized by high-intensity artificial lighting systems. Electricity is used for various types of installations - from lighting, to ventilation, air conditioning and heating. It is therefore justified to use renewable energy technologies in the form of photovoltaic façades in office buildings, which enable even a partial coverage of the electricity demand [4-5]. Thanks to this, when there are surpluses in energy production by PV façades, it is possible to sell it, which also generates financial benefits [6].

Installation of such systems and checking the efficiency of their operation also provides an opportunity to conduct research in terms of self-sufficiency of construction works. In other words, whether it is possible to build and operate a facility that is fully self-sufficient and therefore consumes only as much electricity 
as it is able to produce [7]. Of course, the largest energy gains are generated in a warm climate, where the exposure to the sun is much greater, even in countries located in Europe, for example, in Poland. As it is stated [8] in such countries as, for example, Brazil, where electricity costs are rising, and the costs of investing in photovoltaic panels are getting lower and lower, it is highly beneficial to invest in buildings already fitted with a photovoltaic installation. Very often well-designed buildings become so-called electricity generators, because they produce more energy than is needed for a given object. Thus, such an investment is not only a modern approach in the field of energy, but also constitutes an economic advantage [8]. It should also be added that technology based on the use of photovoltaic installations in buildings is not only an advantage resulting from the production of electricity. Combined solar photovoltaic and thermal systems (PVT) are also very popular, thanks to which it is possible to convert solar radiation into electricity and heat at the same time [9].

Among the many benefits of investments in renewable energy sources, such as PV panels, it should also be remembered that electricity in this type of system is produced only during the day, when the sun is present in the sky, so energy production does not take place 24 hours a day. Of course, photovoltaic technology is constantly evolving and it shows a lot of potential We can be sure that every year more and more innovative solutions will appear [1, 10]. It is influenced, among other factors, by the growing emphasis on the increasing use of alternative sources for electricity production. People attach more and more importance to how the negative impact of human activity on our planet can be reduced. It is assumed that each year the amount of energy produced by environmentally friendly technologies will increase [11]. Ecological solutions are becoming more popular in Poland. It can be observed, that, for example, photovoltaic installations are not used only by entrepreneurs, but also by individual clients.

The direct objective of the research in this work was to determine during which periods of the year and to what extent a photovoltaic façade mounted on the eastern face of the building is able to cover the energy needs of a research office room.

\section{Description of the installation and research room}

The subject of the research presented in this article was an experimental photovoltaic installation, located on the fourth floor of the Lodz University of Technology building, on the eastern elevation. CIS panels (Cooper Indium Diselenide) made of selenium, cooper and indium, which are thin-film panels with an efficiency not exceeding $12 \%$ on average, were used for the construction of the installation. They are light, flame-resistant, made of $3 \mathrm{~mm}$ glass cover (white glass) and a $3 \mathrm{~mm}$ thick glass substrate mounted in an anodic aluminium frame [12]. They are characterized by their aesthetic appearance - a characteristic dark and indiscreet surface, much more homogeneous than the crystalline materials also used for the construction of photovoltaic panels, high flexibility in terms of shapes and dimensions, and most importantly - the ability to convert a significant amount of scattered radiation. These features are the great advantages of CIS panels, which makes them so popularly mounted on the facade of the building and are particularly attractive for architectural applications [13-14]. These panels are very effective and reliable even in the case of unfavorable lighting conditions, for example on cloudy days, and also are not very sensitive to high temperatures. The use of panels based on thin-film technology is not only economical, but also provides ecological benefits, because panels of this type also characterize low-energy production processes.

The view of the research wall is shown in Figure 1. The layout of the panels has been adapted to the existing building. A photovoltaic installation consists of eight PV panels that are arranged side by side to avoid free spaces. They are located around a window opening with an area of $1.44 \mathrm{~m}^{2}$ (the surface area of the glass is 1 $\mathrm{m}^{2}$ ). The window area was optimized at the design stage, so that the amount of daylight entering to room was adequate, consistent with the requirements. At the bottom, under the PV panels, there are six openings that are ventilation ducts [15-16]. Each of the PV panels at maximum efficiency has a maximum power of $80 \mathrm{Wp}$, $35 \mathrm{~V}$ voltage, $2.3 \mathrm{~A}$ current. According to the technical instructions specified by the manufacturer of the photovoltaics panels [12], the maximum system voltage for this model can be as high as $1000 \mathrm{~V}$, while the permissible temperature of use has been set between -40 and $+80^{\circ} \mathrm{C}$. The thickness of each panel is $35 \mathrm{~mm}$ (with a tolerance of: $+0 \mathrm{~mm},-2 \mathrm{~mm}$ ) and weighs approximately $13 \mathrm{~kg} / \mathrm{m}^{2}$. 

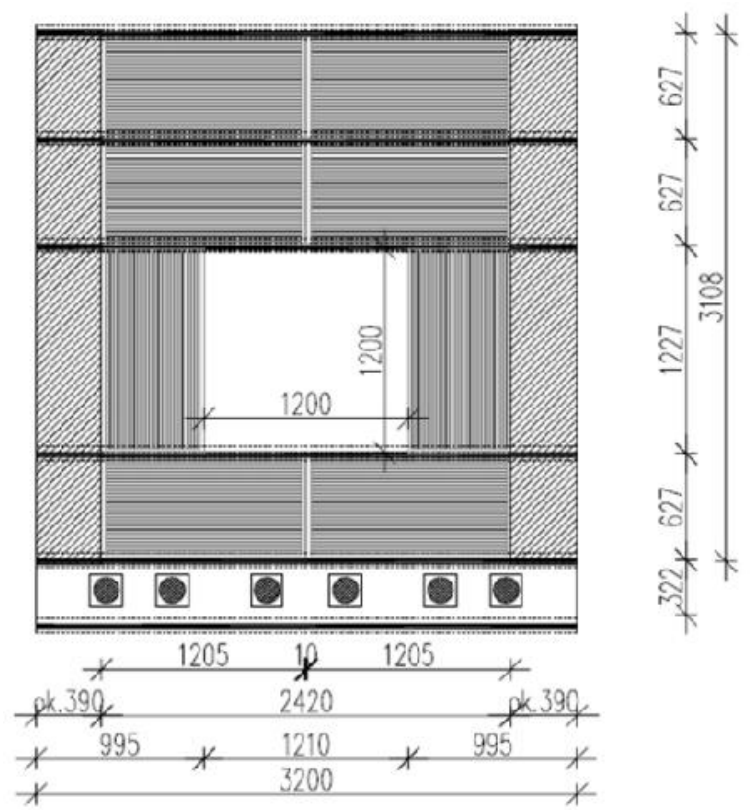

Fig. 1. Visualisation of the experimental façade Source: [17]

The energy produced by the façade before it is used by the receivers passes through a system of devices such as DC meters, charge controllers, batteries and an inverter. When a direct current is converted into alternating current, it can be used to supply the receivers in the research room $[5,16]$.

The receivers of the produced energy are three LED luminaires mounted at a height of $2.6 \mathrm{~m}$. They are a source of artificial lighting in an experimental office room, whose dimensions are $4.4 \mathrm{~m}$ in length, $2.6 \mathrm{~m}$ in width and $2.6 \mathrm{~m}$ in height. The power of a single luminaire is equal to $36 \mathrm{~W}$, whereas the luminous flux is at a level of $3400 \mathrm{Im} \mathrm{[16].}$

\section{Materials and methods}

The work uses data showing the amount of electricity produced by photovoltaic panels. These measurements are collected in the laboratory in which the research room is located. They come from sensors located in the built installation and are saved in a computer program developed for this purpose. Data storage takes place every 5 minutes, 24 hours a day.

The research was carried out in three periods over the years 2015-2017: in the period of the highest demand for lighting, i.e. during the winter period (October-February), in the period of average demand for lighting, the so-called transition period (March-April and September) and during the summer period, when the demand for lighting in the room is relatively small (May-August). An exact division into two analyzed years and periods is presented in Table 1.

Table 1. Characteristics of the analysed years and periods

\begin{tabular}{|c|c|c|}
\hline 1 - Winter period & $\begin{array}{c}10.2015- \\
02.2016\end{array}$ & $\begin{array}{c}10.2016- \\
02.2017\end{array}$ \\
\hline 2 - Transition period & $\begin{array}{c}03-04.2016, \\
09.2016\end{array}$ & $\begin{array}{c}03-04.2017 \\
09.2017\end{array}$ \\
\hline 3 - Summer period & $05-08.2016$ & $05-08.2017$ \\
\hline
\end{tabular}

Source: Author's 
The work also analyzed the possibilities of using the energy produced by the PV façade, taking into account the different sizes of electricity demand by the lighting installation. Due to the fact that there are three luminaires in the research office, and the power of each of them is $36 \mathrm{~W}$, it was assumed that the power demand would be $36 \mathrm{~W}, 72 \mathrm{~W}$ and $108 \mathrm{~W}$, with regard to whether one, two or three luminaires were working at a given time, which depends to a large extent on weather conditions and the personal preferences of the room user.

\section{Results and discussion}

An analysis of the experimental efficiency of the east oriented photovoltaic façade consisted in comparing the amount of energy generated by the installation during the selected characteristic three periods of two consecutive years. This comparison is shown in Figure 2. This analysis shows that year 2 was less favorable in terms of electricity production by the PV façade in each of the analysed periods. However, when comparing the periods distinguished between them, it can easily be seen that the most productive was the summer period, when electricity was produced much more than in the other two periods. Unfortunately, it does not translate into the need for artificial lighting in a room inside the building, which is the smallest in this period, unlike in the winter period, when the least energy is produced, and the use of artificial lighting is greatest, due to the overwhelming number of cloudy days in these months.

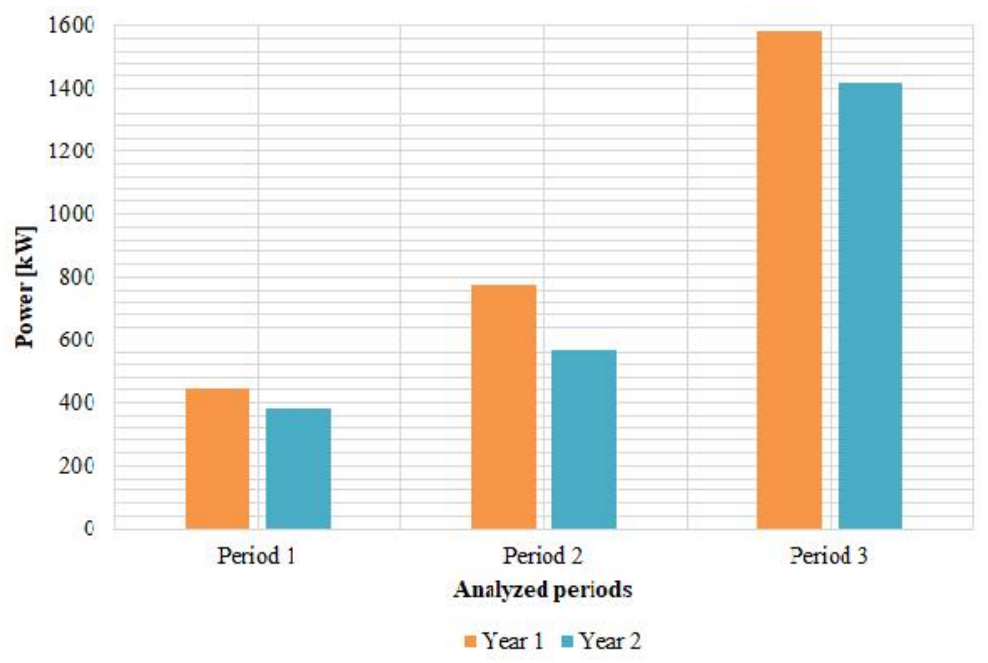

Fig. 2. Energy power generated by the PV façade Source: Author's

The next analysis was to check the possibility of using the energy produced by the PV façade for the needs to power the lighting installation in the research room, taking into account the different demand for electric power through the LED luminaires. An analysis was carried out for each of the three periods, both analysed years, having regard to the three different luminaire power ( $36 \mathrm{~W}, 72 \mathrm{~W}, 108 \mathrm{~W})$.

The first analysis was made for the power of LED luminaires equal to $108 \mathrm{~W}$. It turned out that if all luminaires were $100 \%$ power, only in the summer period, in year 1, from May to August 2016, would the photovoltaic façade be able to cover the energy demand electricity in the morning hours, as illustrated in Figure 3. 


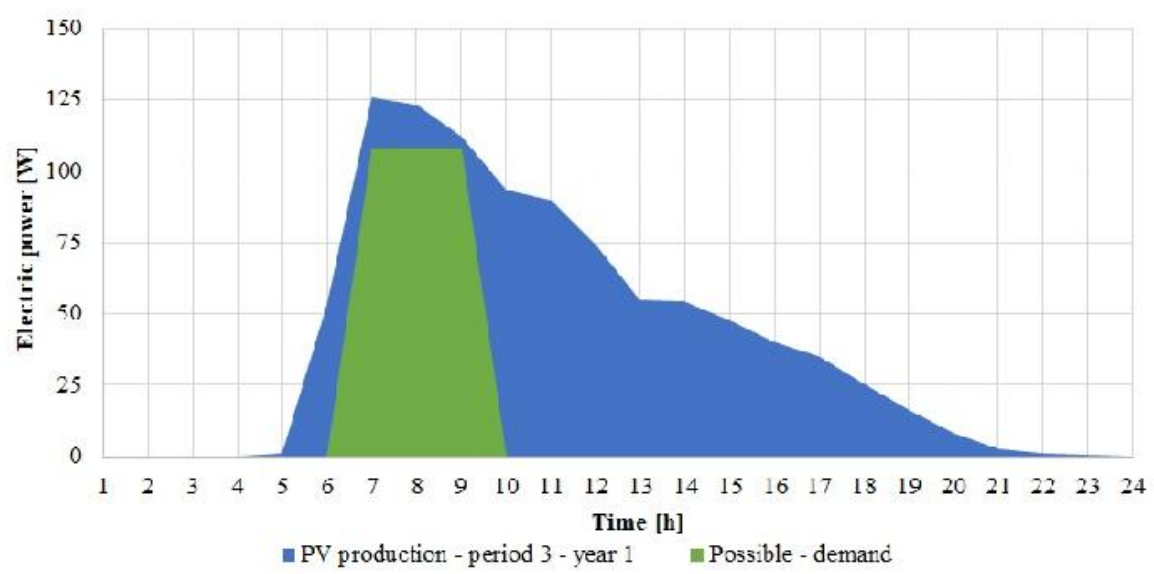

Fig. 3. Monthly averaged electric power generated in year 1, period 3 and possible demand for lighting of $108 \mathrm{~W}$ Source: Author's

In the case when the installed luminaire power was $72 \mathrm{~W}$, the period during which it was impossible to cover any electricity demand for lighting was the period 1 of year 1 , while in the case of year 2 , there were two periods -1 and 2 . In other periods it could have been achieved, but the periods 3 of year 1 and year 2 were the most favourable in this respect. In order to visualize the differences in the daily distribution of the possible power demand, Figure 4 presents the results as in Figure 3, for the period 3 of year 1.

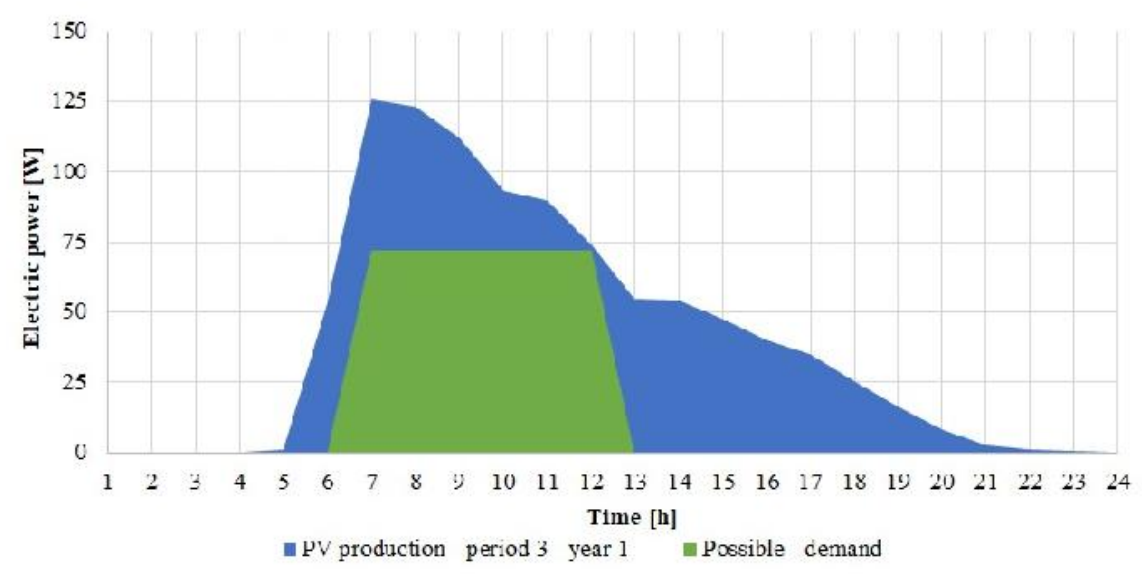

Fig. 4. Monthly averaged electric power generated in year 1, period 3 and possible demand for lighting of $72 \mathrm{~W}$ Source: Author's

The last of the analyzed cases was the establishment of the power of electricity receivers at the level of $36 \mathrm{~W}$. In this case, in the summer, in year 1 and year 2, the façade was able to cover the energy demand for LED luminaires to the greatest extent. The results for the summer period of year 1 are shown in Figure 5 . In the transitional periods of both analyzed years, assuming that work in an office, and thus the need for artificial lighting would take place between 07.00 and 15.00, the façade would also work effectively and cover the demand for the given electrical power at this time. 


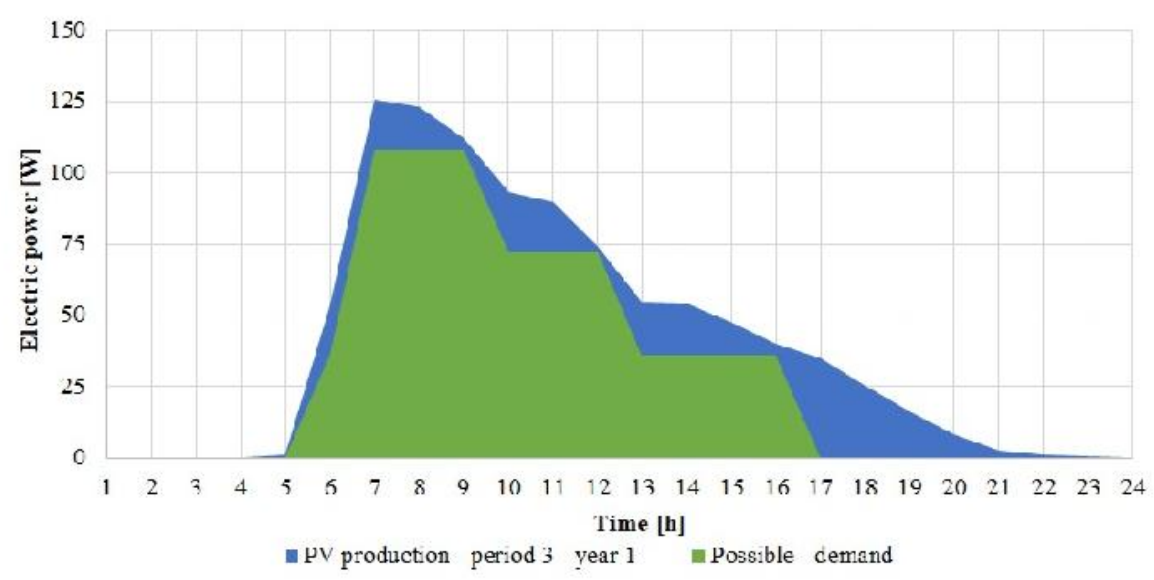

Fig. 5. Monthly averaged electric power generated in year 1, period 3 and possible demand for lighting of $36 \mathrm{~W}$ Source: Author's

However, the only period in which not even the power demand could be met to a small extent, despite the fact that it was as low as possible, was the winter period in year 1, as shown in Figure 6 (therefore, demand energy was not determined in this figure). This means that from all analysed periods of both years it was the only least productive period.

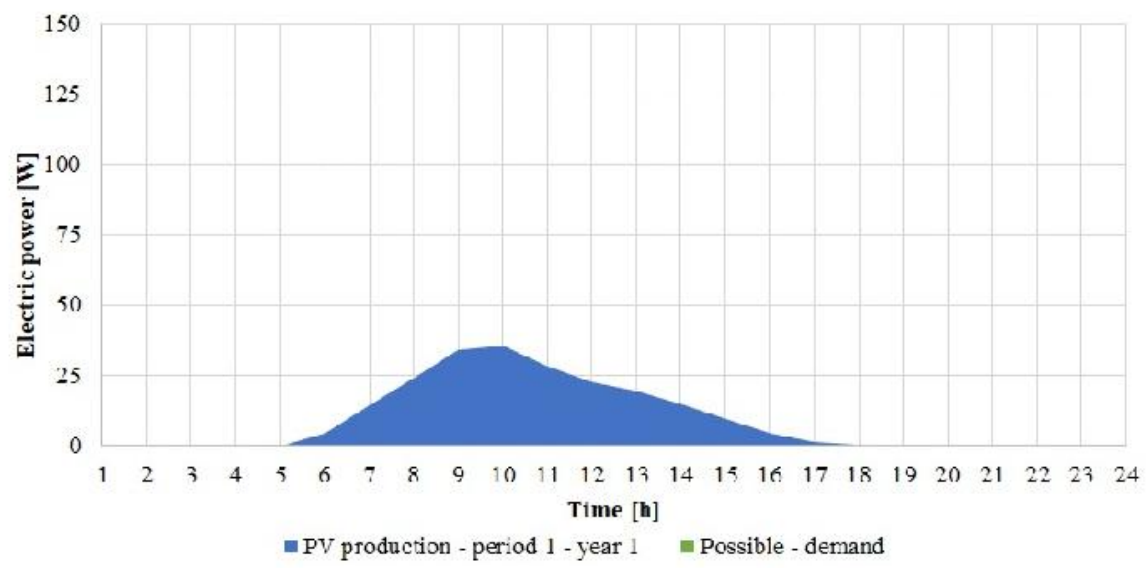

Fig. 6. Monthly averaged electric power generated in year 1 , period 1 and possible demand for lighting of $36 \mathrm{~W}$ or $72 \mathrm{~W}$ or $108 \mathrm{~W}$

Source: Author's

The results shown in Figures 3-6, thanks to the display of data during the day, also enable checking in which hours the façade generates the highest power. Therefore, it seems correct that the largest power gains are generated by the PV façade located on the eastern wall of the building in the morning hours, in other words in the first half of the day.

\section{Summary and conclusions}

Based on the research and data analysis, it can be concluded that in the two analysed years, year 2 was less sunny, compared to year 1 . The energy gains generated by the PV façade in this period were smaller in each of these periods than in year 1 . When comparing all the periods of the analysed years, taking into account the power demand for artificial lighting in an office room, it can be observed that during the summer period the amount of energy generated by the façade is the highest, while the smallest is during the winter period. Unfortunately, this does not translate into the expectations of potential users of the room, whose greatest demand for lighting from artificial sources is in the period when solar radiation reaching the room is the smallest, in other words during the winter period. 
In the case of summer periods, surplus electricity produced can be expected, because the need to use artificial lighting can be low or negligible at this time, due to the possibility of using daylight. Here, it is also important to design the room in such a way that the number of window surfaces is adequate and not less than required. On the other hand, the excess energy, which would not be used for the needs of lighting receivers in this period, could be stored or used, for example, by other receivers, in accordance with the assumptions of the given facility.

Taking into account the needs of the office user throughout the day and examining the possibilities of a photovoltaic installation in terms of electricity production, it is possible to check under which conditions and whether the installation could operate autonomously. Work in this direction will be the next stage of the research. It is also important to take into account, in our research, measurements of incident radiation and to provide more detailed information on PV electrical power during the day to better understand the reason for the decline in photovoltaic power during certain periods. It should also be remembered that in our latitude, the location of the PV facades on the eastern walls is not an ideal location for this type of equipment.

\section{References}

[1] A. Chauhan, V. V. Tyagi, S. Anand, Futuristic approach for thermal management in solar PV/thermal systems with possible applications, Energy Conversion and Management 163 (2018) 314-354.

[2] H. Jędrzejczuk, B. Chwieduk, Analiza energetyczna i ekonomiczna instalacji fotowoltaicznej w wybranym budynku jednorodzinnym, Fizyka Budowli w Teorii i Praktyce Tom VII, Nr 4 (2015): 5-10.

[3] I. Ceron, E. Caamano-Martin, F.J. Neila, 'State of the art' of building integrated photovoltaic products, Renewable Energy 58 (2013) 127-133.

[4] N. Martín-Chivelet, D. Montero-Gómez, Optimizing photovoltaic self-consumption in office buildings, Energy Buildings 150 (2017): 71-80.

[5] A. Zajączkowska, D. Heim, Analiza wykorzystania energii systemu BIPV do zasilania instalacji oświetlenia wbudowanego w budynku biurowym, Fizyka Budowli w Teorii i Praktyce Tom IX, Nr 4 (2017): 39-46.

[6] Solar Power Europe, Renewable self-consumption. Cheap and clean power at your doorstep, Policy Paper, Solar Power Europe, June 2015.

[7] P. Denholm, R.M. Margolis, Evaluating the limits of solar photovoltaics (PV) in traditional electric power systems, Energy Policy 35 (2007) 2852-2861.

[8] M. J. Sorgato, K. Schneider, R. Rüther, Technical and economic evaluation of thin-film CdTe building integrated photovoltaics (BIPV) replacing façade and rooftop materials in office buildings in a warm and sunny climate, Renewable Energy 118 (2018) 84-98.

[9] S. S. Joshi, A.S. Dhoble, Photovoltaic-thermal systems (PVT): Technology review and future trends, Renewable and Sustainable Energy Reviews 92 (2018) 848-882.

[10] B. P. Jelle, Ch. Breivik, The path to the building integrated photovoltaics of tomorrow, Energy Procedia 20 (2012) 78-87.

[11] G. Krajačić, M. Vujanović, N. Duić, ş. Kılkış, M. A. Rosen, M. A. Al-Nimr, Integrated approach for sustainable development of energy, water and environment systems, Energy Conversion and Management 159 (2018) 398-412.

[12] Instrukcja Techniczna. StoVentec ARTline Inlay. Panel fotowoltaiczny do podwieszanych systemów elewacji wentylowanych. Gotowy do montażu. Sto-ispo Sp. z o.o. 
[13] F. Almonacid, C. Rus, L. Hontoria, .J. Muñoz, Characterisation of PC CIS module by artificial neutral networks. A comparative study with other methods, Renewable Energy 35 (2010) 973-980.

[14] K. Kushiya, CIS-based thin-film PV technology in solar frontier K.K., Solar Energy Materials and Solar Cells 122 (2014) 309-313.

[15] D. Knera, D. Heim, Application of a BIPV to cover net energy use of the adjacent office room, Management of Environmental Quality: An International Journal, 2016, Vol. 27 Iss 6, pp. $649-662$.

[16] M. Barecka, A. Borowczyński, D. Heim, D. Knera, E. Szczepańska - Rosiak, A. Wieprzkowicz, I. Zbiciński, Double Criterion Optimisation of Integrated Renewable Energy Systems (RES) and Daylight Utilization. Technology, Technical Solution and Construction of Optimized, External Wall System, German-Polish Energy Efficiency Project (GPEE), 2015.

[17] D. Knera, D. Heim, Energy efficiency of experimental BIPV façade in high temperatures, Sustainable Built Environment, Conference 2016 in Hamburg, Strategies, Stakeholders, Success factors $7^{\text {th }}-11^{\text {th }}$ March 2016, Conference Proceedings (2016) 1364-1373. 


\author{
Monika Janas, Alicja Zawadzka \\ Faculty of Process and Environmental Engineering, Lodz University of Technology, \\ 90-924 Lodz, Wolczanska 213 \\ monika.janas@edu.p.lodz.pl
}

\title{
NEUTRALIZATION OF POULTRY WASTE BY THERMOHYDROLYSIS IN NEAR-CRITICAL WATER
}

\begin{abstract}
The main problem occurring during poultry and animal production is the management of waste generated in slaughterhouses and poultry processing plants. These wastes, due to the bacteriological threat and the difficulty in storage, adversely affect all elements of the environment and thus require quick neutralization. The prospective method of liquidation of this type of waste is thermohydrolysis in near-critical water.

The aim of the work was to examine the decomposition of poultry waste, i.e. waste blood, soft tissues, chicken heads, feathers, subjected to the process of thermohydrolysis in near-critical water. The decomposition process was carried out at a pressure of $10 \mathrm{MPa}$ in the temperature range of $120^{\circ} \mathrm{C}-250^{\circ} \mathrm{C}$ and with a variable residence time in the reactor.

Detailed analysis of the results allowed us to state that the longer the residence time in the reactor, the higher the content of soluble organic compounds in the liquid phase. The beneficial effect of applying the thermohydrolysis process on the increased reduction of organic substances present in the investigated wastes was also demonstrated.
\end{abstract}

\section{Keywords}

animal waste, thermohydrolysis, near-critical water, neutralisation

\section{Introduction}

The process of food production, using various types of raw materials and technologies, is a source of waste, sewage disposal to waters and/or soil, as well as the emission of dust and gases into the atmosphere. The waste generated during meat processing is particularly troublesome, which results from its physical and chemical properties. The main pollutant arising in slaughterhouses and meat processing plants is sewage which contains fats, tissue remains and blood, as well as meat and bone waste. Waste utilization is very complicated due to its biological instability, high water content, constant oxidative stability and sanitary hazard [1-3].

In the past, various types of bone meal obtained from the processing of animal waste constituted an important source of valuable protein in the nutrition of farm animals. The outbreak of bovine spongiform encephalopathy (BSE) and African swine fever (AFR) has resulted in a reduction in the use of these meals in livestock nutrition. In 1988, the UK introduced the first restriction on the use of meat-and-bone meal derived from ruminants in cattle feed. In 1994, restrictions on the feeding of cattle, sheep and goats with meal derived from the processing of mammalian tissue were already in force in all European Union countries. In 2001, a ban was imposed on the use of animal meal and other defined forms of processed animal protein in the nutrition of farmed animals intended for food production. Due to the risk associated with the spread of BSE and AFR diseases and the probable impact of infected meat on humans, the utilization of post-slaughter waste has been subject to severe formal restrictions [1, 4-6].

The current Regulation of the European Parliament and of the Council of 21 October 2009 (WE) no. 1069/2009 laying down health rules as regards animal by-products not intended for human consumption, indicates thermal treatment as the only effective method to eliminate BSE and AFR from the food chain [7]."

One of the methods of thermal treatment of the waste of animal origin is thermohydrolysis in near-critical water. Water in the sub- and supercritical state is an agent that enables the thermal treatment of animal waste. In supercritical water, during the thermohydrolysis process, pathogenic bacteria are neutralized while organic matter is decomposed into compounds of lower molecular weight. The result is a microbe-free mixture consisting of simple organic compounds that pose fewer problems in the further neutralization process. The 
aim of this work is to investigate the process of thermohydrolysis of animal connective tissue as a waste in near-critical water.

\section{Thermohydrolysis in near-critical water}

Water in the sub- and supercritical state, due to its features, is a very attractive reaction medium. Its high diffusivity and heat capacity guarantee fast mass and heat transfer. The ability to control polarity and solvation capacity as well as non-toxicity and widespread availability of the medium enhance the wide use of near-critical water $[9-11,13]$.

At present, around the world, water in near-critical conditions is mainly used in power engineering, geochemistry, chemical synthesis and in innovative technologies for the neutralization or removal of toxic pollutants. A particularly promising solution is the process of supercritical water thermohydrolysis (SCWT). This method consists of the decomposition of organic compounds, using the properties of water after exceeding its critical point $\left(\mathrm{Tcr}=374^{\circ} \mathrm{C}, \mathrm{pcr}=22.1 \mathrm{MPa}\right)$. It is carried out in the liquid phase, thanks to which the decomposition of high molecular organic compounds occurs more effectively and water molecules are incorporated into the structure of these compounds. A characteristic feature of SCWT is an anaerobic reaction environment which guarantees that there are no problems associated with the corrosion of materials from which the apparatus is built. In addition, the products of thermohydrolysis show a significantly milder action on the apparatus walls than the products of supercritical water oxidation $[8-10,13,14]$.

The main direction of research in the field of supercritical water thermohydrolysis is to explain the reaction and identify compounds formed in this process. In the existing literature on the subject, there is a number of publications devoted to the hydrothermal processes of various groups of organic compounds that are highly toxic or are hardly biodegradable [15-17].

Research on the distribution of many groups of organic compounds was conducted by Martino and Savage [18]. At $460^{\circ} \mathrm{C}$ and $25 \mathrm{MPa}$, they investigated the decomposition of cresols, nitrophenols and benzenediols. Efforts to increase the SCWT efficiency with a simultaneous temperature and pressure reduction contributed to the intensification of studies carried out with the use of catalysts. Thermohydrolysis of chemical substances in supercritical water using catalysts was carried out, among others, by Antal et al. [19], Krammer et al. [20], Penniger et al. [21], Wu et al. [22] and Martin et al. [23]. The catalysts used were mainly inorganic compounds, i.e. sodium chloride, calcium chloride, ferric chloride, sulfuric acid and nitric acid. Many publications on hightemperature hydrolysis were also devoted to carbohydrates, in particular glucose which is relatively easily decomposed even at low temperatures [22, 24]. Martinez et al. [25] investigated the hydrothermal decomposition of cellulose under supercritical water conditions. Researchers also became interested in the possibility of using SCWT to neutralize waste [26-29]. Particular attention was paid to the hydrothermal decomposition of polymers and biopolymers, including polyethylene (PE) $[29,30]$. The authors found that water is a very good solvent for decomposing polycarbonates. They obtained $50 \%$ recovery of phenol from the polymer at subcritical temperatures. Imbierowicz and Chacuk [31] checked the possibility of using thermohydrolysis to liquefy sewage sludge in supercritical water conditions. They carried out hydrothermal decomposition of the activated sludge at a temperature ranging from $423 \mathrm{~K}$ to $523 \mathrm{~K}$ and pressure of 0.2-4.0 $\mathrm{MPa}$, and used the obtained results to formulate a kinetic model describing the process. Research on this issue was also conducted by Bougrier et al. [32] and Laurent et al. [28].

The quoted examples of studies on the process of near-critical water thermohydrolysis constitute just a small fraction of research carried out on this subject. The presented results lead to the conclusion that supercritical water thermohydrolysis is characterized by high application potential and due to its advantages can be used in the future on a large scale.

\section{Aim of the work}

The main problem occurring during intensive poultry production is management of the waste generated in hatching plants, slaughterhouses and poultry processing plants. The aim of this work is to investigate the process of thermohydrolysis of poultry waste in near-critical water. 


\section{Experimental}

The object of thermohydrolysis was waste generated during slaughtering and processing of poultry. These were: waste blood, soft tissues (mainly meat), chicken heads and feathers. The investigated waste immediately before thermohydrolysis was ground three times using a PM200 planetary ball mill and directed to a Nade AD18 laboratory homogenizer which guarantees high homogeneity of mixtures. The analysis showed that the waste consisted of $18 \%$ protein, $2 \%$ fat, $16 \%$ fiber, $9 \%$ ash, $1.2 \%$ calcium, $0.9 \%$ phosphorus and other less significant components.

The $100 \mathrm{~g}$ samples prepared in this way were subjected to thermohydrolysis in a Parr $0.5 \mathrm{dm} 3$ stirred batch high-pressure reactor (Fig. 1). Each type of waste from the poultry industry was analyzed separately. The reactor was made of titanium and equipped with a heating jacket, temperature controller, high-speed stirrer, a system of valves for sampling and a process control unit.

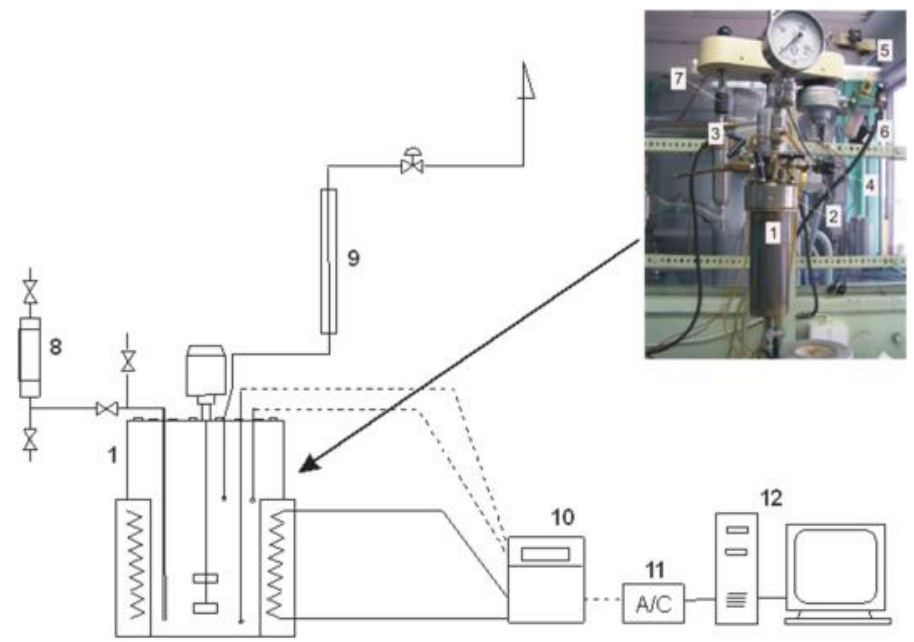

Fig. 1. Schematic of a laboratory setup for testing the process of thermohydrolysis of animal waste in a Parr reactor (1- reactor, 2 - ring, 3 -stirrer, 4 - thermocouple, 5 - turbine, 6 - speed controller, 7 - pivot, 8 - sampling container, 9 - cooler, 10 - controller, 11 - A/C converter, 12 - computer)

Source: Author's

The decomposition process was carried out at a pressure of $10 \mathrm{MPa}$ in the temperature range of $120^{\circ} \mathrm{C}-250^{\circ} \mathrm{C}$ and with residence time in the reactor equal to 30 minutes. The tested samples were analyzed for the content of total organic carbon (TOC) and chemical oxygen demand (COD) in the suspension. TOC was determined by a coulometric method using a Strohlein 702Li/C Coulomat, and the determination of COD was carried out using the dichromate method according to PN-ISO 6060:2006. The method consisted in determining the mass of potassium dichromate in milligrams in terms of oxygen used for oxidation of organic compounds and some inorganic substances present in the analyzed sample.

\section{Results and discussion}

Figure 2 shows results of the COD analysis for samples before and after thermohydrolysis for various fractions of poultry waste. The degree of decomposition of the resulting organic compounds was determined and presented as COD changes in the reaction mass prior to and after the process.

a)

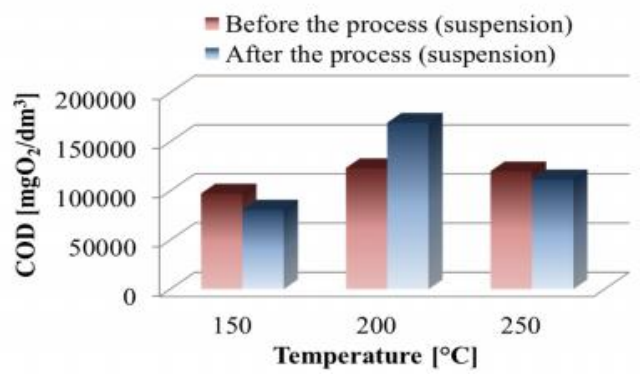

b)

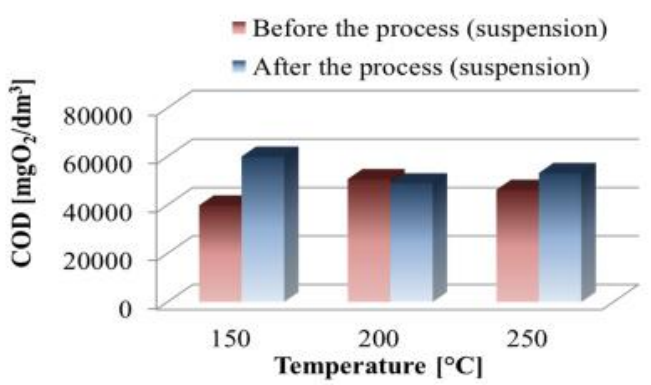


c)

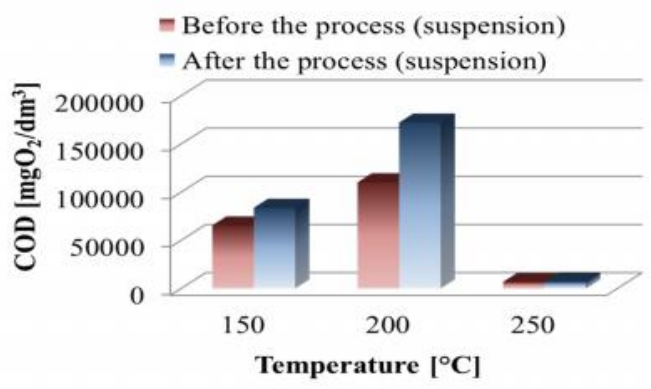

d)

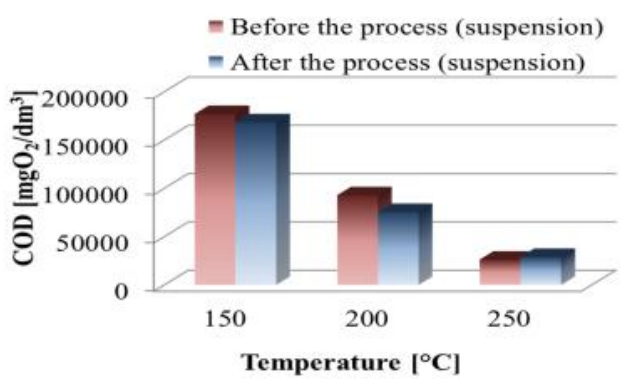

Fig. 2. Changes in COD in the suspension during thermohydrolysis at various temperatures: a) meat, b) feathers, c) chicken heads, d) blood

Source: Author's

When analyzing the presented results, it can be seen that in as many as seven cases the COD of the reaction mass was greater after the process of thermohydrolysis than before it. As a result, satisfactory reproducibility of the test results was not obtained even for the same waste group and the same process conditions.

The TOC indicator was used to further analyze the course of decomposition of the tested waste. The influence of the time of thermohydrolysis on TOC was investigated in the study and the obtained results are presented in Figure 3.

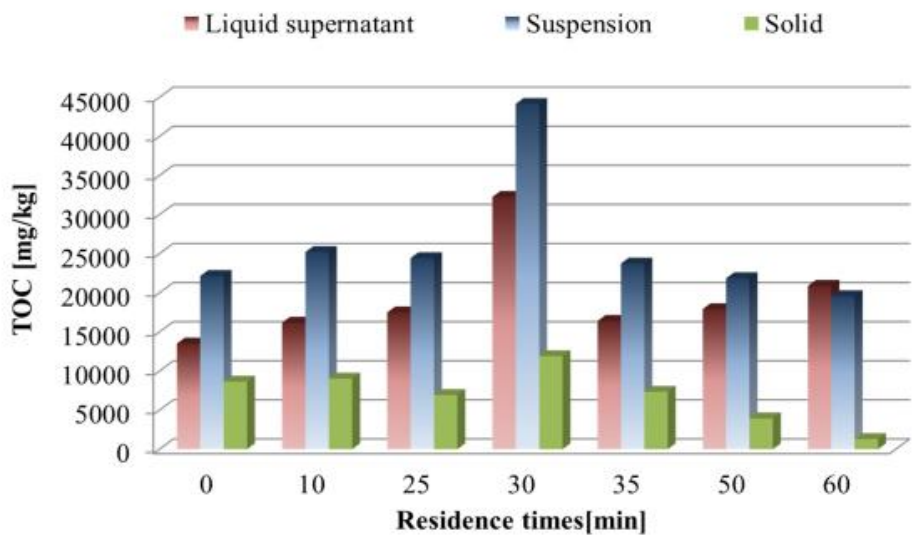

Fig. 3. Changes in TOC concentration $[\mathrm{mg} / \mathrm{kg}]$ in time for the process of meat thermohydrolysis at $200^{\circ} \mathrm{C}$ Source: Author's

A detailed analysis of the results allows us to conclude that the longer the residence time of the mass in the reactor, the higher the content of soluble organic compounds in the liquid phase. This increase is caused by the decomposition of organic compounds in the liquid phase. During the heating of animal waste, biomass dissolution takes place causing an increase in the content of soluble organic compounds in the liquid phase and their decrease in the solid phase. Heating the biomass suspension to $150^{\circ} \mathrm{C}-250^{\circ} \mathrm{C}$ in the reaction system causes that part of organic carbon passes to the liquid phase, while organic carbon present in solid particles obtains a different characteristic than that present in the raw sludge.

\section{Conclusions}

The poultry industry generates large amounts of waste, which in the process of biological processing creates a number of problems. In this connection researchers are looking for more and more efficient methods for neutralization of burdensome production residues.

The paper presents the results of research on the process of near-critical water thermohydrolysis as a method of neutralizing waste from the poultry industry. Both soft and hard parts generated in chicken slaughtering 
process were analyzed. Waste blood coming from the slaughter process, chicken heads and waste feathers as well as muscle tissue in the form of chicken breasts were tested.

As a result of the analyses, it was found that the process of thermohydrolysis of poultry waste depends primarily on the temperature and residence time in the reactor. The longer process time resulted in an increased content of soluble organic compounds in the liquid phase. An important advantage of poultry waste thermohydrolysis is meeting the requirements of legal regulations applicable to the management of waste of animal origin. It is particularly important here to meet the current hygiene requirements for this waste group, which are defined in Regulation (EC) No. 1069/2009 of the European Parliament and of the Council of 21 October 2009 laying down health rules as regards animal by-products not intended for human consumption. This regulation classifies waste of animal origin and defines ways of its neutralization. In the case of the neutralization of material of animal origin with biological methods, it is necessary to pre-pasteurize it at a temperature of at least $70^{\circ} \mathrm{C}$ for low-risk waste or a minimum of $133^{\circ} \mathrm{C}$ for high-risk waste.

In summary, it can be concluded that the process of near-critical thermohydrolysis as a method for neutralizing poultry waste is a particularly promising technological solution. However, it is necessary to continue research on this issue in order to determine the optimal parameters of the process of near-critical thermohydrolysis.

\section{References}

[1] T.L. Oldfield, E. White, N.M. Holden, An environmental analysis of options for utilising wasted food and food residue. J. Environ. Manage. 183 (2016) 826-835

[2] J. Palatsi, M. Vinas, M. Guivernau, B. Fernandez, X. Flotats, Anaerobix digestion of slaughterhouse waste: Main process limitations and microbial community interactions, Bioresource Technology. 102 (2011) 2219-2227

[3] M. Edström, A. Nordberg, L. Thyselius, Anaerobic treatment of animal byproducts from slaughterhouses at laboratory and pilot scale, Appl. Biochem. Biotechnol. 109 (2003) 127-138

[4] P. Klintenberg, M. Jamieson, V. Kinyaga, M. Odlare, Assessing biogas potential of slaugter waste: Can biogas production solve a serious waste problem at abattoirs? Energy Procedia. 61 (2014) 2600-2603

[5] E. Cascarosa, G. Gea, J. Arauzo, Thermochemical processing of meat and bone meal: A review, Renevable and Sustainable Energy Reviews, 16 (1) (2012) 942-957

[6] J. A. Conesa, A. Fullana, R. Font, Thermal decomposition of meat and bone meal, Journal of Analytical and Applied Pyrolysis. 70 (2003) 619-630

[7] Rozporządzenie Parlamentu Europejskiego i Rady z dnia 21 października 2009 r. (WE) nr 1069/2009 określające przepisy sanitarne dotyczące produktów ubocznych pochodzenia zwierzęcego, nieprzeznaczonych do spożycia przez ludzi (Dz.U.UE.L.2009.300.1)

[8] R. Askin, S. Otles, Supercritical fluids, Technologia Alimentaria. 1 (4) (2005) 3-16

[9] M. J. Cocero, Supercritical water processes: Future prospects, The Jurnal of Supercritical Fluids. 134 (2018) $124-132$

[10] A. Martin, M. D. Bermejo, M. J. Cocero, Recent developments of supercritical water oxidation: a patents review, Recent Pat. Chem. Eng. 4 (2011) 219-230

[11] N. Akiya, P. E. Savage, Roles of water for chemical reactions in high-temperature water, Chem. Rev. 102 (2002)

[12] A. Kruse, N. Dahmen, Water - a magic solvent for biomass conversion, The Journal of Supercritical Fluids. 96 (2015) 36-45 
[13] W. He, G. Li, L. Kong, H. Wang, J. Huang, J. Xu, Application of hydrothermal reaction in resource recovery of organic wastes, Resour. Conserv. Recycl. 52 (2008) 691-699

[14] P. Kritzer, Corrosion in high-temperature and supercritical water and aqueous solutions: a review, The Journal of Supercritical Fluids. 29 (2004) $1-29$

[15] L. Zhang, C. Xu, P. Champagne, Overview of recent advances in thermos-chemical conversion of biomass, Energy Convers. Manag. 51 (2010) 969-982

[16] H. A. Ruiz, R. M.Rodriguez-Jasso, B. D. Fernandes, A. A. Vicente, J. A. Teixeira, Hydrothermal processing, as an alternative for upgrading agriculture residues and marine biomass according to the biorefinery concept: $A$ review. Renevable and Sustainable Energy Reviews. 21 (2013) 35-51

[17] S. S. Toor, L. Rosendahl, A. Rudolf, Hydrothermal liquefaction of biomass: a review of subcritical water technologies, Energy. 36 (2011) 2328-2342

[18] Ch. J. Martino, P. E. Savage, Thermal decomposition of substituted phenols in supercritical water. Ind. Eng. Chem. Res 36 (5) (1997) 1385-1390

[19] M. J. Antal, A. Brittain, C. DeAlmeida, S. Ramayya, J. C. Roy, Heterolysis and hemolysis in supercritical water, ACS Szmp. Ser. 329 (1987) 77-86

[20] P. Krammer, H. Vogel, Hydrolysis of esters in subcritical and supercritical water, The Journal of Supercritical Fluids. 16 (2000) 189-206

[21] J. M. L. Penninger, R. J. A. Kersten, H. C. L. Baur, Hydrolysis of diphenylether in supercritical water. Effects of dissolved $\mathrm{NaCl}$, The Journal of Supercritical Fluids. 17 (2000) 215-226

[22] X. Wu, J. Fu, X. Lu, Hydrothermal decomposition of glucose and fructose with inorganic and organic potassium salts, Bioresource Technology. 119 (2012) 48-54

[23] A. Martin, A. Navarrete, M. D. Bermejo, Applications of supercritical technologies to $\mathrm{CO}_{2}$ reduction: Catalyst development and process intensification, The Jurnal of Supercritical Fluids. 134 (2018) 141-149

[24] J. Yin, Z. Cheng, L. Guo, S. Li, H. Jin, Products distribution and influence of nickel catalyst on glucose hydrothermal decomposition, International Journal of Hydrogen Energy. 42 (7) (2017) 4642-4650

[25] C. M. Matinez, D. A. Cantero, M. D. Bermejo, M. J. Cocero, Hydrolysis of cellulose in supercritical; water: reagent concentration as a selectivity factor. 22 (4) (2015) 2231-2243

[26] Y. Matsumura, T. Minowa, B. Potic, S. R. A. Kersten, W. Prins, W. P. M. van Swaaij, B. van de Beld, D. C. Elliott, G. C. Neuenschwander, A. Kruyse, M. J. Antal Jr., Biomass gasification in near- and super-critical water: status and prospects, Biomass Bioenergy. 29 (2005) 269-292

[27] J. Mucha, R. Zarzycki, Analysis of wet oxidation process after initial thermohydrolysis of excess sewage sludge, Water Research. 42 (12) (2008) 3025-3032

[28] J. Laurent, M. Casellas, H. Carrere, C. Dagot, Effects of thermal hydrolysis on activated sludge solubilization, surface properties and heavy metals biosorption, Chemical Engineering Journal. 166 (2011) 841849

[29] ] Z. Fang, Jr. R. L. Smith, H. Inomata, K. Arai, Phase behavior and reaction of polyethylene in supercritical water at pressures up to $2,6 \mathrm{GPa}$ and temperatures up to $670^{\circ} \mathrm{C}$, The Journal of Supercritical Fluids. 16 (2000) 207-216

[30] F. Dubelley, E. Planes, C. Bas, E. Pons, B. Yrieix, L. Flandin, The hydrothermal degradation of PET in laminated multilayer, European Polymer Journal. 87 (2017) 1-13 
[31] M. Imbierowicz, A. Chacuk, Kinetic model of excess activated sludge thermohydrolysis, Water Research. 46 (2012) 5747-5755

[32] C. Bougier, J. P. Delgenus, H. Carrerre, Effects of thermal treatments on five different waste activated sludge samples solubilisation, physical properties and anaerobic digestion, Chemical Engineering Journal. 139 (2008) 236-244 


\title{
Justyna Czerwińska, Grzegorz Wielgosiński \\ Lodz University of Technology, Faculty of Process and Environmental Engineering \\ Wólczańska 213, 90-924 Łódź, Poland, justyna.czerwinska@edu.p.lodz.pl
}

\section{CHANGES IN THE POLLUTION OF LODZ VOIVODSHIP RAINWATER AS A RESULT OF CHANGES IN POLLUTANT IMMISSIONS}

\begin{abstract}
Increasing urbanization rates, particularly in cities, cause an increase in pollutant emissions into the environment. Immission of pollutants is the amount of particulate or gaseous pollutants that is received by the environment. Natural precipitation, i.e. rainwater, is polluted during the contact with air. As a result of atmospheric precipitation groundwater and soil become polluted. The pollutants also penetrate surface water, causing further contamination. In rainwater that goes to the sewage system, there are pollutants such as hydrocarbons, heavy metals, slurries, plant protection products and many more. This is largely dependent on the type of management of the catchment, its sanitary condition, and the time and intensity of precipitation. Another important factor is the composition of pollutants emitted into the atmospheric air in each area. The work shows changes in the pollution of rainwater in Lodz Voivodship in the years 2010-2016 and presents analysis of the data collected by the Regional Inspectorate for Environmental Protection. The analysis shows that the state of rainwater is steadily deteriorating which is directly related to air quality.
\end{abstract}

\section{Keywords}

air quality, emission, immission, rainwater pollution

\section{Introduction}

According to the classical concept, atmospheric air is a colourless and odourless mixture of gases and aerosols forming a heterogeneous layer called the Earth's atmosphere [1]. The composition of dry and clean air is as follows: nitrogen (78.08\%); oxygen (20.95\%); argon (0.93\%); carbon dioxide (ca. $0.036 \%$ ); noble gases, hydrogen and methane $(0.004 \%)$; water vapour (in variable amounts).

Any substances introduced into the air and causing changes in its permanent composition are considered as pollutants. They may threaten human and animal health as well as soil and water environment. More and more often, their source are human activities. The main source of anthropogenic emissions of pollutants into the air is the combustion of solid, liquid and gaseous fuels. Depending on the way in which pollutants are emitted into the air, three types of emission sources can be distinguished [2-7]:

- $\quad$ point emission sources - high chimneys in large buildings, from which pollutant plume is raised to a considerable height and dispersed;

- line emission sources - groups of point sources located along straight lines, most often represented by road, rail and water transport, where emissions from individual emitters add up along communication routes;

- $\quad$ surface emission sources - emission sources with a height of several orders lower than the occupied area, which include mainly residential areas with individual heating systems, but also agricultural areas, landfills, mine heaps and open-pit mines.

Pollutants emitted into the atmosphere as a result of wet deposition get to the hydrogeochemical circulation and together with atmospheric precipitation fall to the earth surface penetrating it [8-12]. The chemical composition of atmospheric precipitation depends on pollutants contained in the air and meteorological conditions prevailing in the area [13-17]. The main meteorological factors affecting the spread of pollutants in atmospheric air are temperature, pressure, wind speed, thermodynamic equilibrium of the atmosphere and air humidity [18-22]. Lodz Voivodship is located in central Poland where variable meteorological conditions occur. The inflow of humid maritime polar air mass from the south-west directions dominates. Periodically, the circulation changes, and dry continental air mass from Russia, from the eastern direction, advances into the country. Due to the topography in the area of Lodz Voivodship there are also changeable conditions of pollutant dispersion in the air [23]. Although in the vicinity of Lodz there are mostly uplands, the main city of the region, i.e. Lodz, is not free of smog episodes. During the year, there are about 50 smog days in Lodz, i.e. 
the days when permissible concentrations are exceeded - PM10 particulate matter in this case [24-28]. A particular increase in the concentration of this pollutant is observed at low temperatures, low wind speed, low pressure and high air humidity. These are characteristic features of the so-called "Polish smog" [29] which differs significantly from the London smog widely described in the literature.

The term "Polish smog" is a neologism, because until now such a concept in professional literature has not been used. It was created to distinguish the phenomenon appearing more and more often in Polish cities, from the well-known in the literature and repeatedly described acid smog and photochemical smog [30-34]. The "Polish smog" differs mainly from those mentioned earlier - it consists primarily of particulate particles - both PM10 and PM2.5, as well as PM1 and numerous polycyclic aromatic hydrocarbons, including benzo(a)pyrene. So, another term - "dust smog" can also be used. These pollutants are typical for the combustion of solid fuels in low-efficiency furnaces, in the absence of exhaust gas cleaning systems, in other words, household furnaces. Using a broader definition, the basic cause of poor air quality in Polish cities is called "low emission", i.e. emissions from household heating systems fired by solid fuels and from traffic, in particular vehicles operated without catalysts. If we add to this inversion phenomena relatively frequent in Poland during the winter period (e.g. after frost and eastern circulation of the West warmer polar-sea masses, or weather periods with high pressure, lack of cloudiness and low wind), it appears that in many areas of the country there are excellent conditions for the formation of smog, above all "dusty", but sometimes also acid smog. The characteristic feature of the "Polish smog" is its formation at high-altitude weather and negative air temperatures. In winter, this is often associated with cloudless weather, causing significant temperature drops and inversions at night. In addition, at low temperatures there is a growing demand for heat, hence the increased emissions of pollutants from individual heating systems. A result is dust concentration in the lower part of the atmosphere, repeatedly exceeding the permitted levels or "dust smog". An interesting fact is that most often it is not accompanied by exceeding the permissible concentrations of $\mathrm{SO}_{2}$ or $\mathrm{CO}$, typical for acid smog.

However, not only the "low emission" is a source of air pollution in Poland. The largest coal-fired power plant in Europe (and the largest brown-coal power plant in the world) is located in the Lodz Voivodship, the third in the world in terms of installed capacity in coal-fired power plants. Annually, its emitters bring into the air approximately $30000 \mathrm{Mg} \mathrm{SO}_{2}, 27800 \mathrm{Mg} \mathrm{NO}, 21400 \mathrm{MgCO}$ and about $780 \mathrm{Mg}$ dust. Apart from the power station in Bełchatów, the major sources of emissions of the above mentioned pollutants are plants in Lodz (approximately $4100 \mathrm{Mg} \mathrm{SO}_{2}$ ) as well as in Piotrków Trybunalski, Zgierz, Sieradz, Pabianice, Zduńska Wola and Skierniewice emitting annually from 280 to $420 \mathrm{Mg} \mathrm{SO}$. These objects also have a significant impact on the state of air pollution in the province, and most likely also on the chemistry of atmospheric precipitation.

The study presents analysis of the data collected by the Regional Inspectorate for Environmental Protection in Lodz in the years 2006-2016 regarding emissions and immission of sulphur dioxide $\mathrm{SO}_{2}$ and nitrogen oxides $\mathrm{NO}_{x}$ ( $\mathrm{NO}$ and $\mathrm{NO}_{2}$ ). The amount of atmospheric precipitation and its chemical composition were also analyzed. Particular attention was paid to four substances: sulphates, chlorides, nitrites and nitrates as the expected effects of acidification of precipitation by $\mathrm{SO}_{2}$ and $\mathrm{NO}_{\mathrm{x}}$ emissions.

\section{Research and results}

In Lodz Voivodship the Regional Inspectorate for Environmental Protection carries out continuous measurements of air quality at 9 automatic stations and 19 manual stations. The following substances are measured: sulphur dioxide, nitrogen oxides, carbon monoxide, ozone, benzene, benzo(a)pyrene and particulate matter PM10 and PM2.5. The main components of the "Polish smog" are dust in various forms: suspended particulate matter with a particle diameter below $10 \mu \mathrm{m}$, respirable dust with a particle diameter below $2.5 \mu \mathrm{m}$ and soot particles with a diameter below $1 \mu \mathrm{m}$. Additionally, in cooperation with the Institute of Meteorology and Water Management at the monitoring station in Sulejów, measurements of rainwater quality are carried out. On the basis of the collected air quality data, the Regional Inspectorate for Environmental Protection in Lodz runs an air quality portal where residents can obtain information about the current air quality. It is graded on a 6-point scale from very bad to very good. On the basis of the collected data, an annual assessment of air quality in the Voivodship is also prepared. In Figures 1 and 2 below, the location of air quality monitoring stations in the Lodz region is presented.

In Lodz Voivodship the meteorological data were analyzed in two stations: Lodz and Sulejow. The wind rose for these stations is shown in Fig. 3 and 4. 


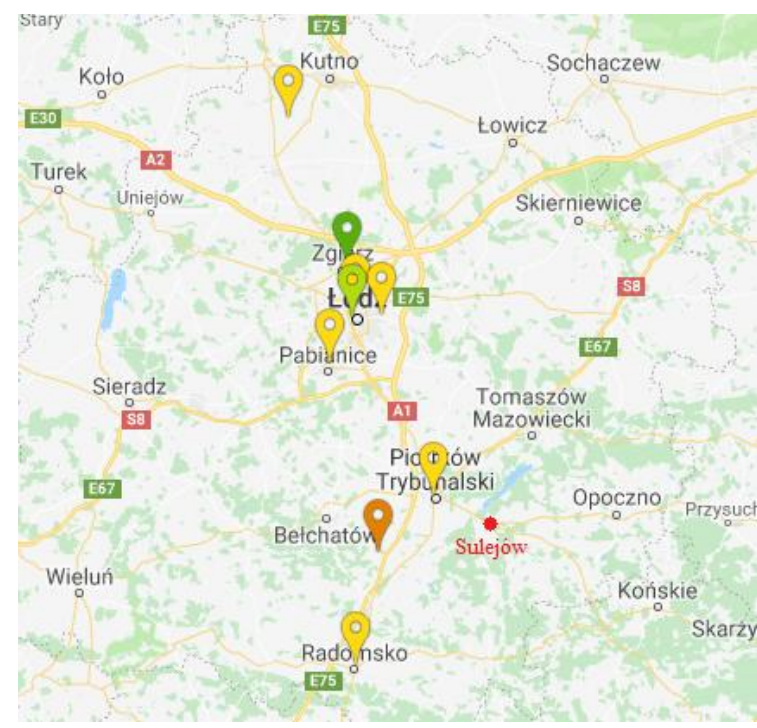

Fig. 1. Location of air quality automatic monitoring stations and rainwater collection station in Sulejow [35] Source: Author's

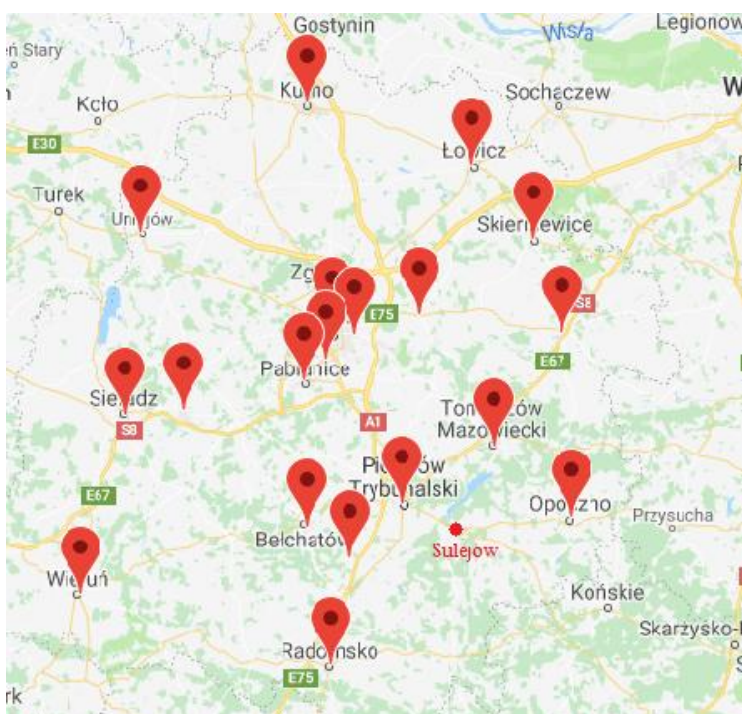

Fig. 2. Location of air quality manual monitoring stations and rainwater collection station in Sulejow [36] Source: Author's

The measuring station in Lodz is equipped with analyzers for continuous measurement of such pollutants as $\mathrm{PM} 10, \mathrm{SO}_{2}, \mathrm{NO}, \mathrm{NO}_{2}, \mathrm{O}_{3}$ and $\mathrm{CO}$ and benzene, $\mathrm{NO}_{x}$ and $\mathrm{PM} 2.5$. All measurements are based on reference methods recognized by the European Commission [37]:

- for PM10 this is the weakening of beta radiation (the method equivalent to the reference method);

- for $\mathrm{SO}_{2}$, this is ultraviolet fluorescence conforming to the PN-EN 14212:2013-02 (EN 1412:2012) method [38];

- for $\mathrm{NO}$ and $\mathrm{NO}_{2}$ this is chemiluminescence, according to the PN-EN 14211:2013-02 (EN 14211:2012) method [39];

- $\quad$ for $\mathrm{O}_{3}$ this is ultraviolet photometry, according to the PN-EN 14625:2013-02 (EN 14625:2012) method [40];

- for CO this is non-dispersive infrared spectroscopy, according to the PN-EN 1426:2013-02 (EN 14626:2012) method [41].

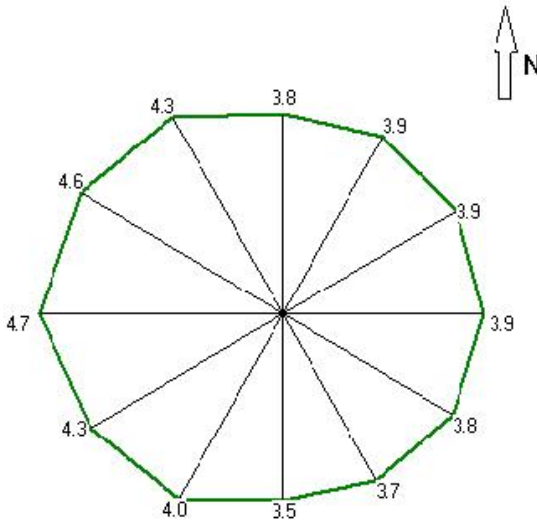

Fig. 3. Wind rose for Lodz meteorological station Wind speed in $\mathrm{m} / \mathrm{s}$ Source: Author's

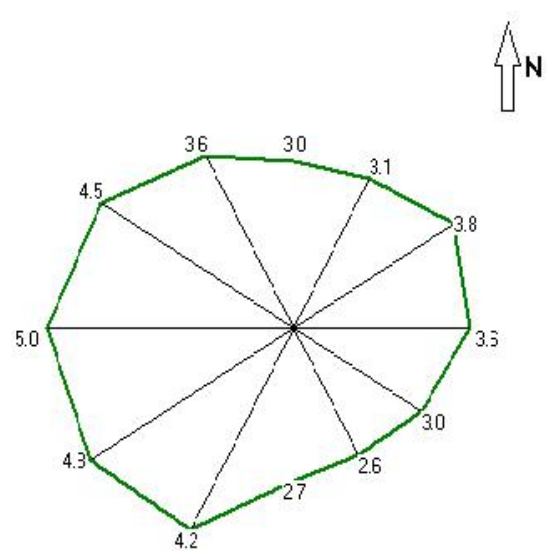

Fig. 4. Wind rose for Sulejow meteorological station Wind speed in $\mathrm{m} / \mathrm{s}$ Source: Author's

Based on the collected data, the values of sulphur dioxide emission in the discussed period were analyzed. Figure 5 shows the distribution of point, surface and line emissions in the years 2009-2016. It is easy to notice that the line emission in the analyzed period was practically constant, its average value in the analyzed period was about $750 \mathrm{Mg} /$ year. In the case of surface emissions in 2005 and 2006, there was a slight increase. The 
highest emission values were recorded for point emission, which in 2016 drastically decreased to around $130,000 \mathrm{Mg} /$ year.

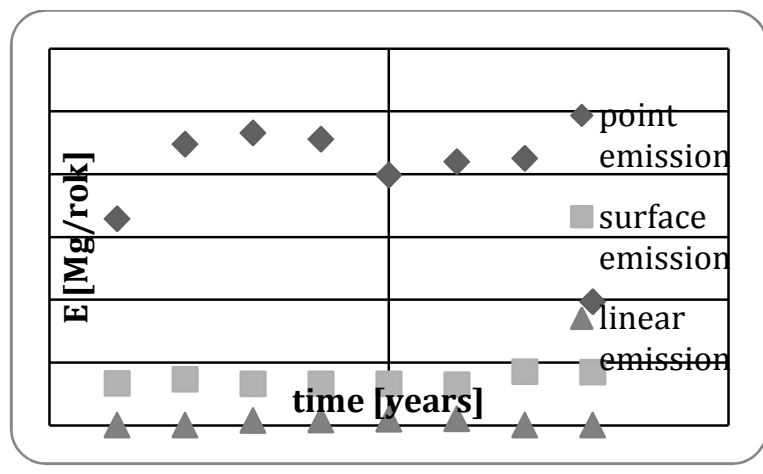

Fig. 5. $\mathrm{SO}_{2}$ emission in the years 2006-2016 in Lodz Voivodship

Source: Author's

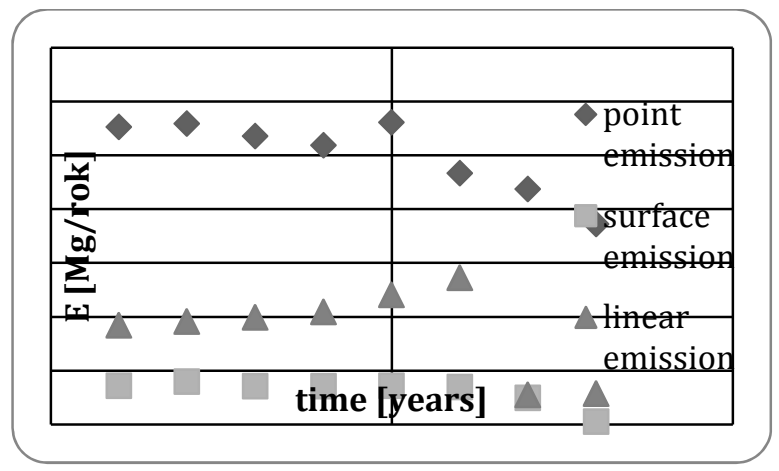

Fig. 6. $\mathrm{NO}_{\mathrm{x}}$ emission in the years 2006-2016 in Lodz Voivodship

Source: Author's

Changes in nitrogen oxide emissions in 2006-2016 were also analyzed (Fig. 6). As in the case of sulphur dioxide emissions, the highest values were recorded for point emissions, which started to decrease since 2014. A similar trend was observed for surface and line emissions, which also decreased at the end of the analyzed period.

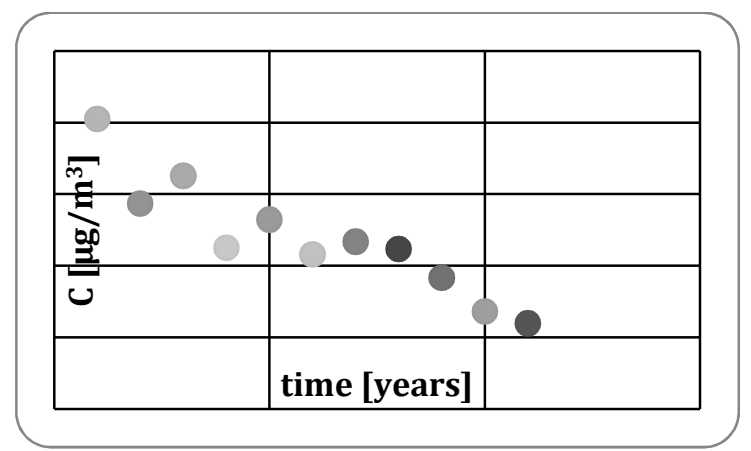

Fig. 7. $\mathrm{SO}_{2}$ immission in the years 2006-2016 in Lodz Voivodship

Source: Author's

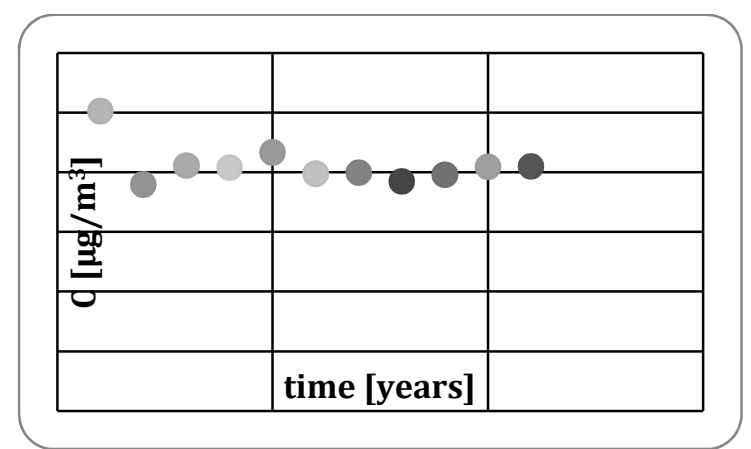

Fig. 8. $\mathrm{NO}_{\mathrm{x}}$ immission in the years 2006-2016 in Lodz Voivodship

Source: Author's

The next stage of the analysis is the comparison of immission data for sulphur dioxide and nitrogen oxides. For sulphur dioxide, a large decrease in the value of recorded concentrations was noted. In the initial period, the average concentration of this pollutant was about $20 \mu \mathrm{g} / \mathrm{m}^{3}$ (Fig. 7), and in the final one $6 \mu \mathrm{g} / \mathrm{m}^{3}$. Nitrogen oxides showed a stable tendency and their concentration was about $20 \mu \mathrm{g} / \mathrm{m}^{3}$ (Fig. 8).

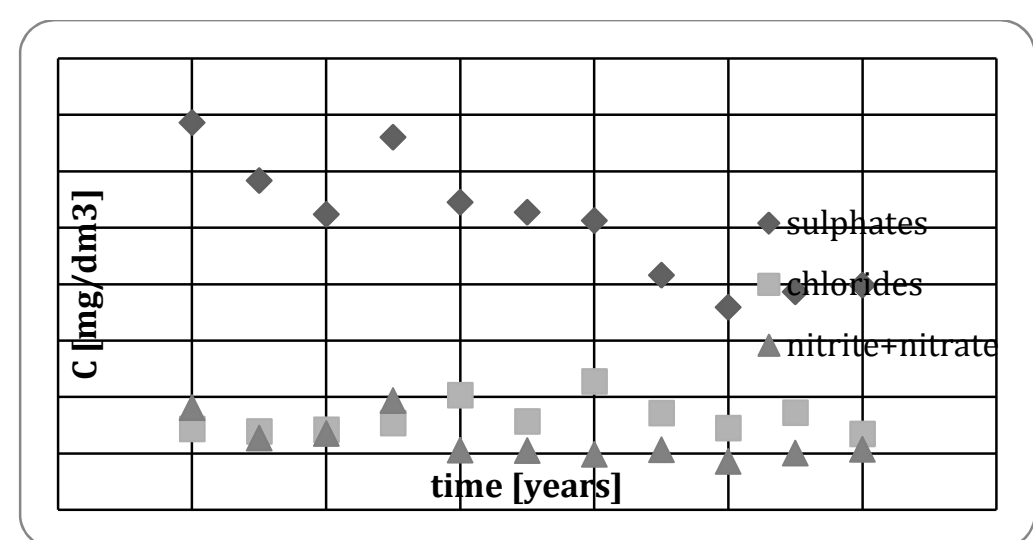

Fig. 9. Chemical composition of rainwater in the years 2006-2016 in Lodz Voivodship Source: Author's 
Figure 9 shows chemical composition of atmospheric precipitation. In the analyzed period, the concentrations of chlorides, nitrites and nitrates remained at a constant level and did not exceed $1.5 \mathrm{mg} / \mathrm{dm}^{3}$. The concentration of sulphates was more than twice as high as other pollutants, although since 2009 it has been falling.

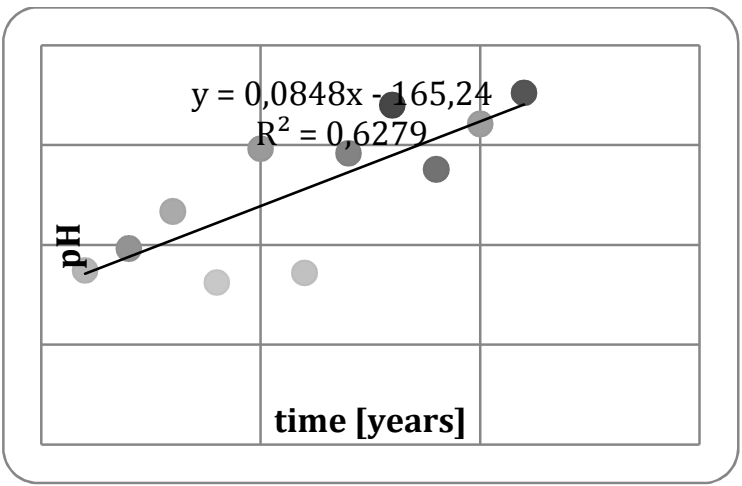

Fig. 10. The $\mathrm{pH}$ of rainwater in the years 2006-2016 in Lodz Voivodship Source: Author's

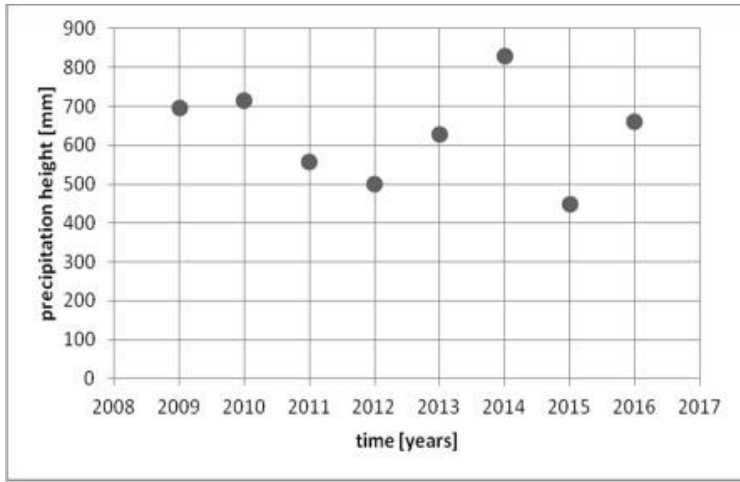

Fig. 11. Annual precipitation total in the years 2009-2016 in Lodz Voivodship Source: Author's

In the analyzed period, the $\mathrm{pH}$ value systematically increased from approximately 4.80 up to 5.80 (Fig. 10). This value indicates a decreasing, but still occurring acidity of atmospheric precipitation, which may cause soil degradation and, consequently, a decrease in soil sorption properties and its fertility. The $\mathrm{pH}$ value of rainwater was not related to the annual precipitation total (Fig. 11). The highest annual precipitation total was recorded in 2014. During this time, the $\mathrm{pH}$ value decreased, compared to previous years.

\section{Summary and conclusions}

The Lodz Voivodship is not one of the most polluted areas in Poland, although the largest point source of pollutant emissions in Poland is located in the region - the Bełchatów power plant. As part of this work, it was decided to analyse changes in both the point as well as linear and surface emissions of pollutants from 20092016 and to check whether emission changes had an impact on the chemistry of atmospheric precipitation recorded during the analysed period. The subject of analysis were the data of the Regional Inspectorate for Environmental Protection and Institute of Meteorology and Water Management monitoring station in Sulejów for the above-mentioned period.

The analysis showed that in the discussed period of 2009-2016, the point emission of sulphur dioxide and nitrogen oxide in Lodz Voivodship decreased. In the case of sulphur dioxide, surface and line emissions remained on a similar level, while for nitrogen oxides there was a significant increase in the line emission. However, this did not affect this pollutant immission which remained constant. The values of pollutant emissions and immissions are reflected by the chemical composition of rainwater. The concentrations of sulphates decreased in the analyzed period, while those of chlorides, nitrites and nitrates changed only slightly.

Based on these data, it can be concluded that main pollutants emitted to the atmosphere that have an impact on the chemical composition of atmospheric precipitation in the Lodz Voivodship, are sulphur dioxide and other sulphur compounds. The total reduction of emissions of acid gases such as $\mathrm{SO}_{2}$ and $\mathrm{NO}_{\mathrm{x}}$ results in a decrease in acidity (i.e. increase in $\mathrm{pH}$ ) of atmospheric precipitation. Therefore, it is confirmed that there is a causal relationship between the emission and immission of these pollutants as well as the chemical composition (and in particular the $\mathrm{pH}$ values) of atmospheric precipitation.

\section{References}

[1] Inspekcja Ochrony Środowiska, Wojewódzki Inspektorat Ochrony Środowiska w Łodzi, Kompleksowy raport o stanie środowiska w województwie łódzkim za lata 2013-2015, Łódź 2016

[2] Wojewódzki Inspektorat Ochrony Środowiska w Łodzi, Raport o stanie środowiska w województwie łódzkim, Biblioteka Monitoringu Środowiska, Łódź 2017 
[3] Wojewódzki Inspektorat Ochrony Środowiska w Łodzi, Raport o stanie środowiska w województwie łódzkim, Biblioteka Monitoringu Środowiska, Łódź 2016

[4] Wojewódzki Inspektorat Ochrony Środowiska w Łodzi, Raport o stanie środowiska w województwie łódzkim, Biblioteka Monitoringu Środowiska, Łódź 2015

[5] Wojewódzki Inspektorat Ochrony Środowiska w Łodzi, Raport o stanie środowiska w województwie łódzkim, Biblioteka Monitoringu Środowiska, Łódź 2014

[6] Wojewódzki Inspektorat Ochrony Środowiska w Łodzi, Raport o stanie środowiska w województwie łódzkim, Biblioteka Monitoringu Środowiska, Łódź 2013

[7] Wojewódzki Inspektorat Ochrony Środowiska w Łodzi, Raport o stanie środowiska w województwie łódzkim w 2011 roku, Biblioteka Monitoringu Środowiska, Łódź 2012

[8] A. Mishra, A.K. Singh, K.A. Singh, P. Pandey, S. Yadav, A.H. Khan, S.C. Barman, Urban air pollution and its effects on rain water characteristics in Lucknow City India, Journal of Environmental Research and Development, volume 6, no. 4 (2012), 1127-1132.

[9] L.Ch. Guo, Y. Zhang, H. Lin, W. Zeng, T. Liu, J. Xiao, S. Rutherford, J. You, W. Ma, The washout effects of rainfall on atmospheric particulate pollution in two Chinese cities, J Environ Prot, 215 (2016), 195-202.

[10] W. Ouyang, B. Guo, G. Cai, Q. Li, S. Han, B. Liu, X. Liu, The washing effect of precipitation on particulate matter and the pollution dynamics of rainwater in downtown Beijing, Sci Total Environ, 505 (2015), 306314.

[11] Pantelaki, A. Papatzelou, D. Balla, A. Papageorgiou, D. Voutsa, Characterization of dissolved organic carbon in rainwater of an urban/coastal site in Mediterranean area, Sci Total Environ, 627 (2018), 14331441.

[12] P. Siudek, M. Frankowski, Atmospheric deposition of trace elements at urban and forest sites in central Poland - insight into seasonal variability and sources, Atmospheric Research, 198 (2017), 123-131.

[13] A.G. Gaddamwar, Analytical study of rain water for the determination of polluted or unpolluted zone, Int J Environ Sci, volume 1, no. 6 (2011), 1317-1322.

[14] B.A. Cottrell, M. Gonsior, L.M. Isabelle, W. Luo, V. Perraud, T.M. McIntire, J.F. Pankow, P. Schmitt-Kopplin, W.J. Cooper, A.J. Simpson, A regional study of the seasonal variation in the molecular composition of rainwater, Atmospheric Environment, (77) 2013, 588-597.

[15] S. Musayev, E. Burgess, J. Mellor, A global performance assessment of rainwater harvesting under climate change, Resources, Conservation \& Recycling, 132 (2018), 62-70.

[16] S. Taguchi, K. Murai, M. Takamatsu, Y. Hayakawa, S. Tamizu, M. Kuwata, Y. Katayama, H. Kuramitz, N. Hata, Interpretation of the concentrations of aldehydes in rainwater over a wide area and local areas of Japan by some dominant factors, Atmospheric Environmental, 61 (2012), 588-596.

[17] D. Huybrechts, E. Verachtert, S. Vander, C. Polders, L. Van den Abeele, Polluted rainwater runoff from waste recovery and recycling companies: Determination of emission levels associated with the best available techniques, Waste Manag, 54 )2016, 74-82.

[18] V. San, V. Spoann, J. Schmidt, Industrial pollution load assessment in Phnom Penh, Cambodia using an industrial pollution projection system, Sci Total Environ, 615 (2018), 990-999.

[19] M. Leśniok, Prądnik. Prace Muz. Szafera, Zanieczyszczenie powietrza i opadów atmosferycznych na obszarze Ojcowskiego Parku Narodowego, 19 (2009), 109-118.

[20] A. Jarosiewicz, Opad atmosferyczny jako źródło substancji biogenicznych - na przykładzie jeziora Dobra (Polska północna), Inżynieria Ekologiczna, 296 (2012), 48-56.

[21] P.D. Hien, P.D. Loc, N.V. Dao, Air pollution episodes associated with East Asian winter monsoons, Sci Total Environ, 409 (2011), 5063-5068.

[22] P.D. Hien, M. Hangartner, S. Fabian, P.M. Tan, Concentrations of $\mathrm{NO}_{2}, \mathrm{SO}_{2}$ and benzene across Hanoi measured by passive diffusion samplers, Atmospheric Environmental 88 (2014), 66-73.

[23] K. Kożuchowski, Meteorologia i klimatologia, Wydawnictwo Naukowe PWN, ISBN 9788301149758, Warszawa 2007.

[24] Wojewódzki Inspektorat Ochrony Środowiska w Łodzi, Raport o stanie środowiska w województwie łódzkim w 2010 roku, Biblioteka Monitoringu Środowiska, Łódź 2011

[25] Wojewódzki Inspektorat Ochrony Środowiska w Łodzi, Raport o stanie środowiska w województwie łódzkim w 2009 roku, Biblioteka Monitoringu Środowiska, Łódź 2010

[26] Wojewódzki Inspektorat Ochrony Środowiska w Łodzi, Raport o stanie środowiska w województwie łódzkim w 2008 roku, Biblioteka Monitoringu Środowiska, Łódź 2009

[27] Wojewódzki Inspektorat Ochrony Środowiska w Łodzi, Raport o stanie środowiska w województwie łódzkim w 2007 roku, Biblioteka Monitoringu Środowiska, Łódź 2008 
[28] Wojewódzki Inspektorat Ochrony Środowiska w Łodzi, Raport o stanie środowiska w województwie łódzkim w 2006 roku, Biblioteka Monitoringu Środowiska, Łódź 2007

[29] G. Wielgosiński, J. Czerwińska, O. Namiecińska, R. Cichowicz, Smog episodes in the Lodz agglomeration in the years 2014-17, E3S Web of Conferences, 28 (2018), 01039.

[30] M. Zhou, G. He, M. Fan, Z. Wang, Y. Liu, J. Ma, Z. Ma, J. Liu, Y. Liu, L. Wang, Y. Liu, Smog episodes fine particulate pollution and mortality in China, Environ. Res., 136, (2015), 396-404.

[31] D. Mira-Salama, C. Grüning, N.R. Jensen, P. Cavalli, J.P. Putaud, B.R. Larsen, F. Raes, H. Coe, Source attribution of urban smog episodes caused by coal combustion, Atmos. Res., 88, (2008), 294-304.

[32] H.S. Kim, J.B. Huh, P.K. Hopke, T.M. Holsen, S.M. Yi, Characteristics of the major chemical constituents of PM2.5 and smog events in Seoul, Korea in 2003 and 2004, Atmos. Environ., 41, (2007), 6762-6770.

[33] C. Muiwijk, P.J.C. Schrijvers, S. Wuerz, S. Kenjereš, Simulations of photochemical smog formation in complex urban areas, Atmos. Environ., 147, (2016), 470-484.

[34] A. Whittakers, K. BéruBé, T. Jones, R. Maynard, R. Richards, Killer smog of London, 50 years on: particle properties and oxidative capacity, Sci. Total Environment, 334-335, (2004), 435-445.

[35] http://www.wios.lodz.pl/Stacje_pomiarowe,211

[36] http://www.wios.lodz.pl/Stacje_pomiarowe,212

[37] http://www.wios.lodz.pl/Lodz-Gdanska_16,211,11.

[38] PN-EN 14212:2013-02 (EN 14212:2012). Ambient air - Standard method for the measurement of the concentration of sulphur dioxide by ultraviolet fluorescence.

[39] PN-EN 14211:2013-02 (EN 14211:2012). Ambient air. Standard method for the measurement of the concentration of nitrogen dioxide and nitrogen monoxide by chemiluminescence.

[40] PN-EN 14625:2013-02 (EN 14625:2012). Ambient air. Standard method for the measurement of the concentration of ozone by ultraviolet photometry.

[41] PN-EN 14626:2013-02 (EN 14626:2012). Ambient air. Standard method for the measurement of the concentration of carbon monoxide by non-dispersive infrared spectroscopy. 


\title{
Marek Michalski \\ AGH University of Science and Technology \\ ul. Gramatyka 10, 30-067 Krakow, Poland, Marek.Michalski@zarz.agh.edu.pl
}

\section{DEVELOPMENT OF NUCLEAR POWER AS AN ALTERNATIVE TO FOSSIL FUELS}

\begin{abstract}
Research into environmental pollution and global warming has induced the energy industry and various levels of government to reduce their dependence on fossil fuels, especially coal and oil. One of the options being considered is increasing nuclear power generation, which has the advantage of high production capacity that can be fully utilized, low fuel consumption and low cost relative to the amount of electricity being generated. However, despite technological progress, the share of nuclear energy in the world's energy mix is decreasing, especially in countries with highly developed economies. The reasons for this are high capital expenditures and their uncontrolled increase, fear of contamination of the natural environment in the event of a failure or terrorist attack as well as difficulties in long-term disposal of radioactive waste. This article analyzes the development of nuclear power as an alternative to fossil fuels in the pursuit of sustainable development, in particular with regard to investment outlays, the cost of generating electricity, environmental protection and security.
\end{abstract}

\section{Key words}

Energy, electricity, power, nuclear, innovation, management.

\section{Introduction}

Following the industrial revolution that relied mainly on steam power, in the 19th century, the second industrial revolution (also referred to as the technological revolution) laid the foundation for widespread use of electricity. The need for electricity was fueled primarily by three inventions:

- The incandescent lightbulb allowed longer working hours and the prospect of increasing the quality of life throughout the world.

- The electric motor was an ideal alternative to steam power offering countless applications ranging from mechanical tools, to powering elevators and ships.

- The advent of electrochemistry, especially electrolysis and electroplating, allowed mass production of many relatively inexpensive chemicals, metals and products of unprecedented quality at significantly reduced cost. This opened entirely new frontiers and started a new era in manufacturing.

As world gross domestic product (GDP) continues to rise in the 21st century, increasingly more people in developing countries are rapidly expanding the range of modern products and services that they use. This leads to a forecasted growth in the use of primary fuel sources for the foreseeable future. However, as shown in Figure 1, the fuel mix is expected to change somewhat with the quickly expanding use of renewable energy sources and natural gas, while oil, coal and nuclear production are expected to stagnate.

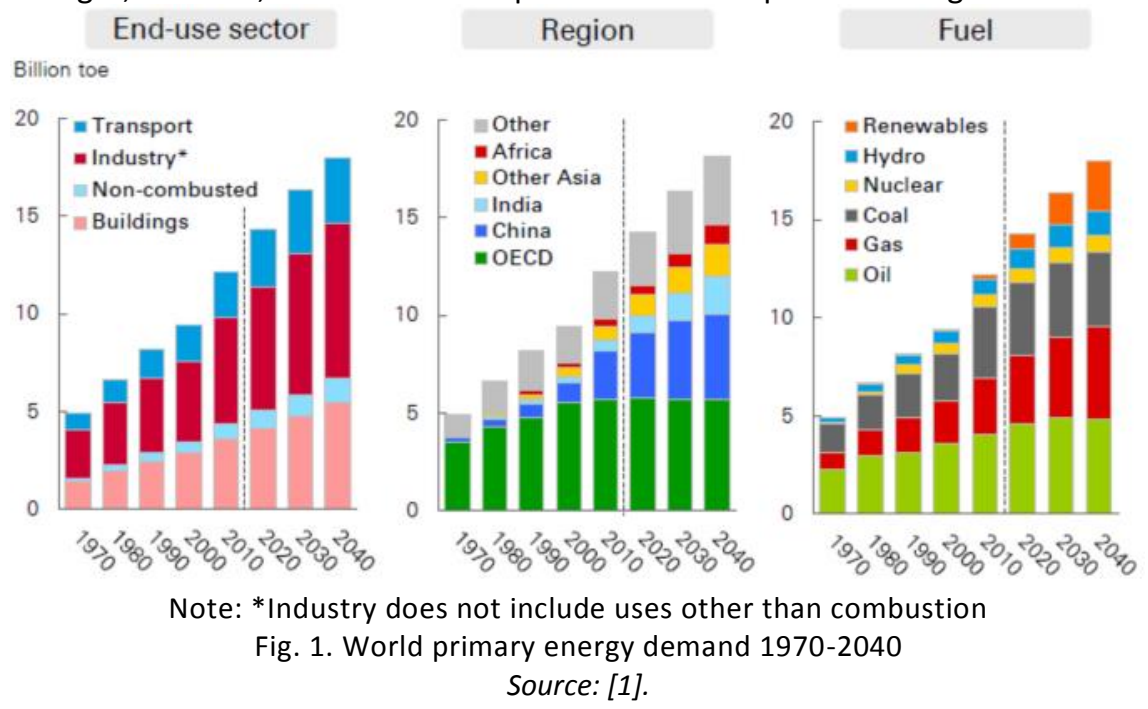


The case of highly developed economies, such as the European Union (EU), is different in that coal consumption began decreasing in the 1980s and overall demand followed the same trend in the 2000s (Figure 2).

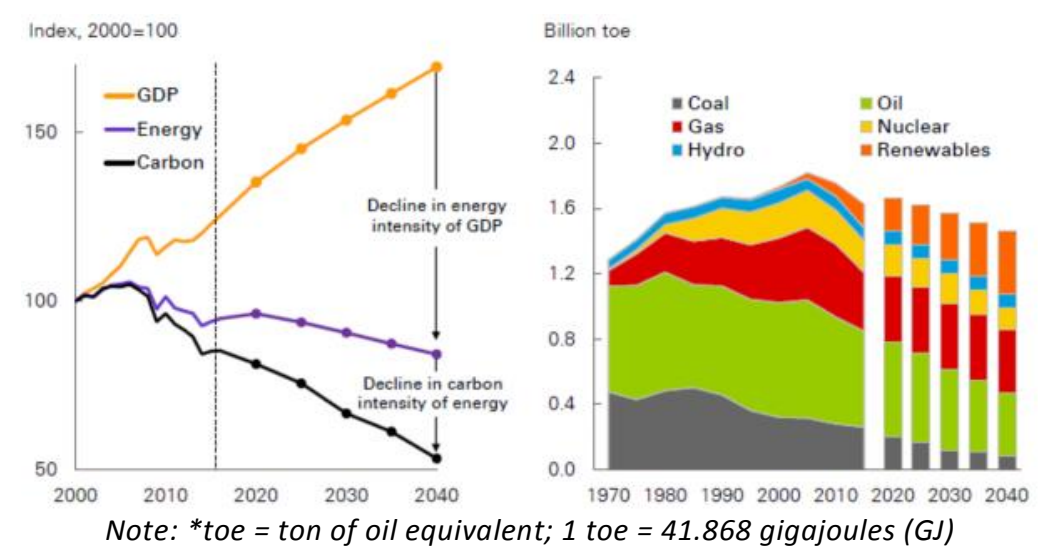

Fig. 2. EU's GDP, energy, $\mathrm{CO}_{2}$ emissions and primary energy demand 2000-2040

Source: [1].

In the 21st century, EU's GDP continues to increase but energy use started to decline due to decreasing energy intensity, i.e. the amount of energy used per unit of GDP - a measure of an economy's energy efficiency. Declining energy intensity and increasing use of renewables, mainly wind, hydro and solar power, results in a decline of carbon intensity too. This trend is expected to continue in the foreseeable future [2].

\section{Nuclear power development}

Despite significant gains in energy efficiency in highly developed countries, as mentioned previously, growing world GDP is correlated with increasing energy consumption. Furthermore, world electricity consumption is growing almost twice as fast as primary energy demand due to the ease in which it may be converted to other forms of energy such as mechanical energy to drive machinery and vehicles or heat. World electricity production has quadrupled from 6,131 TWh (terawatt hours) in 1973 to 24,973 TWh in 2016. The share of nuclear power has risen from $3.3 \%$ to $10.4 \%$ during this time. The only sources of power that grew faster than this were non-hydro renewables and waste (Figure 3 ).
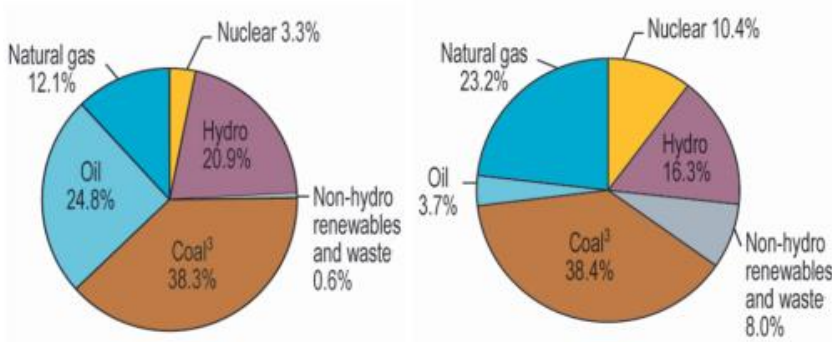

$6131 \mathrm{TWh}$

24973 TWh

Fig. 3. Electrical energy consumption in 1973 and 2016

Source: [3].

The first nuclear power plants began operation in the 1950s, beginning in the Soviet Union in 1954, followed by the United Kingdom in 1956, the United States in 1957 and then Belgium, Canada, France, Germany, Italy, Japan and Sweden in the 1960s[4]. However, as shown in Figure 4, nuclear power development has stagnated in recent years.

Presently, the United States is the largest producer of nuclear energy with a production of 840 TWh, that is almost one third of the world's total and close to $20 \%$ of the country's electricity production. At $73 \%$, France has the biggest share of nuclear power in the world. Ukraine is second with a share of $50 \%[3]$. 
In 2018, the construction of nine plants providing 10.4 GW (gigawatts) of nuclear power were connected to the grid - seven in China, two in Russia. This was the largest addition since 1990. By comparison Poland's average energy demand is about $20 \mathrm{GW}$ and installed production capacity is over $40 \mathrm{GW}$. Currently, 55 additional nuclear power plants in 18 countries with a total capacity of $56,6 \mathrm{GW}$ (including 11 reactors in China alone) are under construction - all of them are due to start operating by the mid-2020s. In Japan, the operation of 12 nuclear reactors was resumed after they were taken offline following the Fukushima Daiichi nuclear disaster in 2011 [5-8].

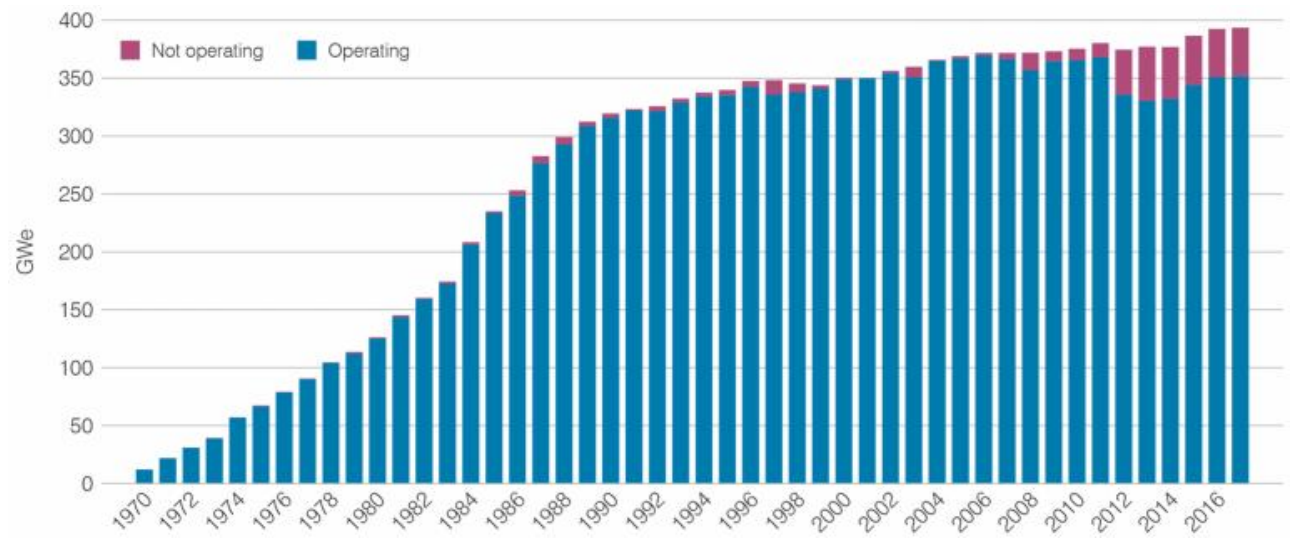

Fig. 4. World nuclear generating capacity Source: [9].

According to forecasts by the International Energy Agency (IEA), worldwide production of electricity from nuclear power plants will gradually increase over the next 20 years but the growth will be much slower than the overall rate of growth for electricity demand [5]. Therefore, the share of nuclear energy in supply will decrease.

However, nuclear power plants have a high capacity factor (average ratio of actual production to maximum production) relative to most other types of fuel. This is due to the relatively low cost of nuclear fuel and the possibility of almost continuous operation at full power. This is in contract to relatively expensive fuels such as oil and natural gas or production from renewables which is dependent on the amount of water flowing, wind speed or insolation.

At the end 2018, Europe has the largest installed nuclear power capacity in the world: $164 \mathrm{GW}$. Of this, almost 40\% (63 GW) is installed in France, 9.5 GW in Germany, 8.9 GW in the United Kingdom and 8.6 GW in Sweden. The United States is in second place with a production capacity of $99 \mathrm{GW}$, followed by China, Japan and Russia. However, this is expected to change with the largest increase forecasted in China with capacity almost tripling by 2030, India (up to $63 \mathrm{GW}$ in 2032) and to a lesser extent Russia (up to $30 \mathrm{GW}$ in 2040). However, according to governmental plans to phase out nuclear power, the installed capacity in the EU, Japan and Korea is to be reduced [5, 7]. Planned retirements and additions are shown in Figure 5. According to forecasts by the IEA, the production of electricity from nuclear power plants will gradually increase over the next 20 years but the growth will be much slower than the overall rate of growth for electricity demand. Therefore, the share of nuclear energy in supply will decrease.

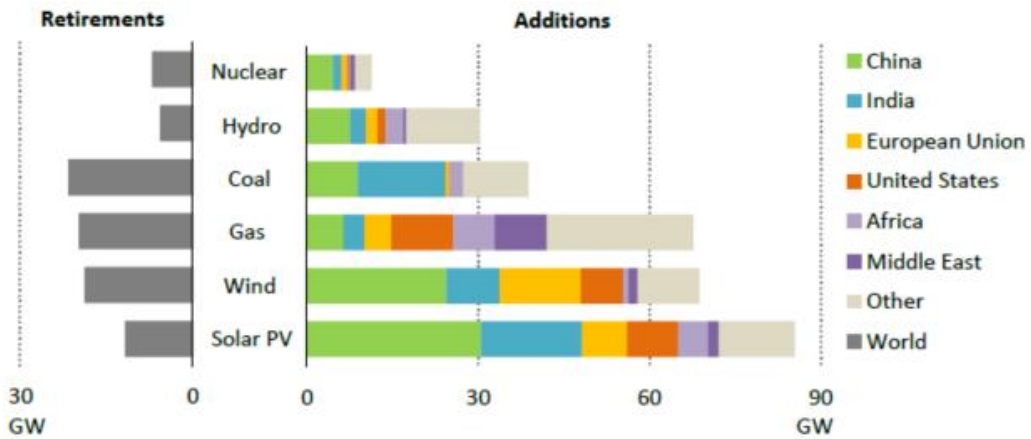

Fig. 5. Closing of existing and building new nuclear power plants forecast for 2017-2040 Source: [7]. 
It is estimated that the construction of new nuclear power plants will consume USD 1.1 trillion by 2040, of which $63 \%$ will take place in developing countries [5].

\section{Nuclear fuel cycle and supply}

The nuclear fuel cycle (Figure 6) starts with uranium mining and milling providing natural uranium that may be combined with recycled uranium. This is then converted and enriched to produce uranium hexafluoride (and depleted uranium that has mainly military but also some civilian applications).

Enriched uranium hexafluoride is used to make fuel for nuclear power plants. The fuel can be supplemented by plutonium taken from reprocessing of nuclear waste or military grade plutonium that has been transferred for civilian use. Spent fuel from nuclear power stations is highly radioactive and hot. It is usually placed into interim storage in water pools to help dissipate the heat. After this, it is sent for reprocessing into recycled uranium (the process also generates radioactive waste) or waste disposal. The recommended strategy for waste disposal is to place it in deep geological repository (DGR) chosen for their remoteness from inhabited zones as well as their geological as well as hydrogeological characteristics and stability to minimize the risk of ground, water and air contamination. DGRs are under development but they are not yet operational. Finland, France and Sweden are at various stages of constructing and licensing DGRs, with the first DGR to be operational in Finland in the early 2020s.

Uranium deposits are usually located in rocks. Most reserves have concentrations of about 1/1000 (i.e. $0.1 \%$ ). Deposits can may be mined using both surface (open pit) and underground mining. Uranium reserves, i.e. resources that may be economically mined using proven technology, are usually defined as reasonably assured resources (RAR) that may be extracted at a cost of no more than $80 \mathrm{USD} / \mathrm{kg}$ of uranium [7]. The estimates of reserves change as a result of technological progress in uranium deposit mapping and mining technology.

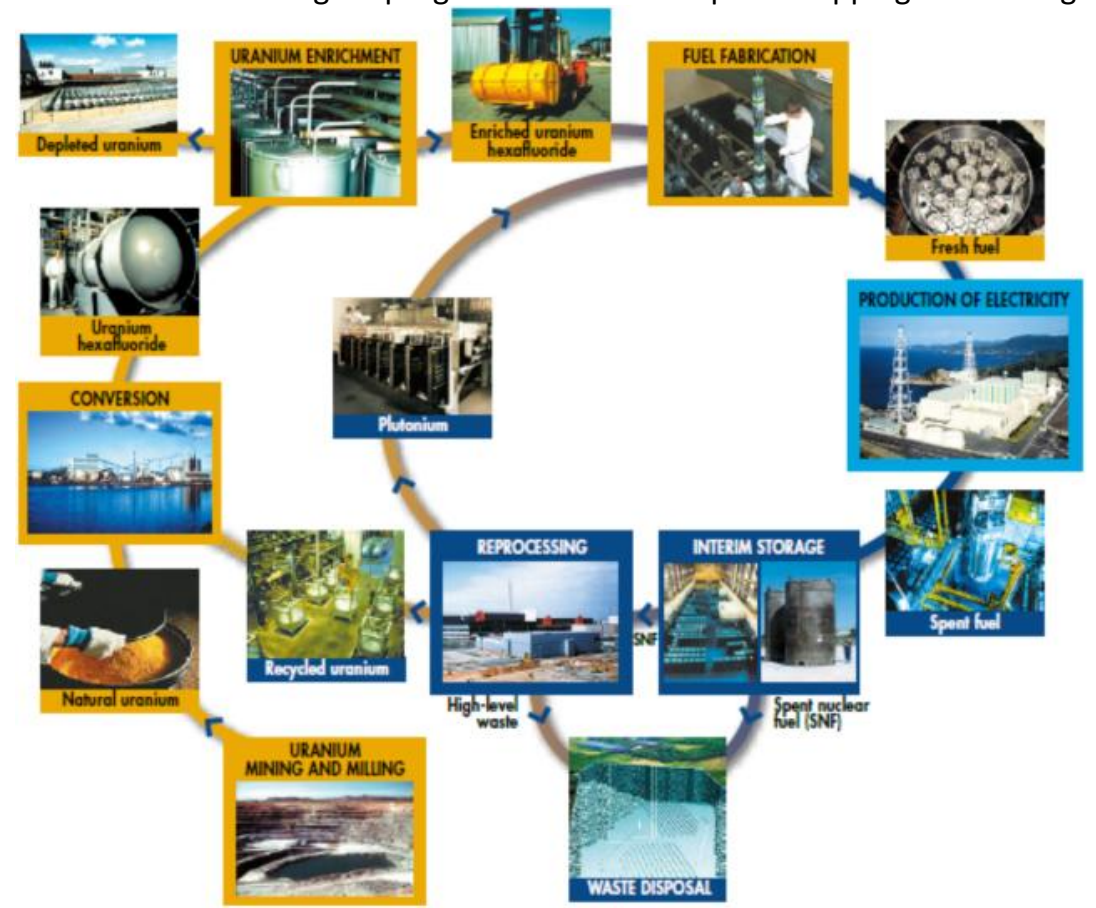

Fig. 6. Nuclear fuel cycle Source: [9].

World uranium resources and reserves are more dispersed than hydrocarbon resources (Figure 7). Existing uranium reserves (in the $<$ USD 80/kgU category) are estimated at $1.28 \mathrm{Mt}$ (million tons), will last for 20 years at current production rates of $0.05934 \mathrm{Mt} / \mathrm{year}$, whereas total identified resources in the <USD 260/kgU category amounting to $7.99 \mathrm{Mt}$ are expected to last for 130 years at the current consumption level [10]. Some studies add an estimate of undiscovered resources, resulting in larger values, such as about 200 years for total resources in the <USD $260 \mathrm{kgU}$ category [7]. The incentive for exploration is currently low given the relatively low prices tied to small production volumes and stagnating nuclear power development around the world. 
Nevertheless existing resources are more than adequate to meet demand through 2035, even in the Nuclear Energy Agency's (NEA's) high demand scenario.

Kazakhstan provides almost $40 \%$ of the world's uranium supply, Canada $22.5 \%$, Australia $10.1 \%$ and the remaining producers less than $6 \%$ each [7]. The market is driven by demand considering the low production volumes and relatively abundant supply. Production may be hindered by environmental issues [11].

Explosives are sometimes used to aid in the mining of the ore but most of it is extracted mechanically. After extraction, the ore is milled into a powder, which is then treated with chemicals, such as sulfuric acid, and dried into a powder called "yellowcake" due to its specific color. The procedure using acid creates liquid waste that is usually stored in large tanks. The yield is about one kilogram of yellowcake per two tons of uranium ore [12, 13].

In underground mining of uranium, a chemical process called in situ leaching (ISL) is used below earth's surface. A hole is drilled in the rock and a chemical solution is pumped into it to dissolve and absorb the uranium. The solution is then brought to the surface via another hole and the uranium is extracted from it. In general, this procedure should have less impact on the environment than other procedures. However, there is potential risk for pollution since not all contaminated liquid can be pumped out. Therefore, there is a risk of groundwater contamination, especially since groundwater flow models for mines may be inaccurate $[12,13]$. ISL accounts for about half of the world uranium production.

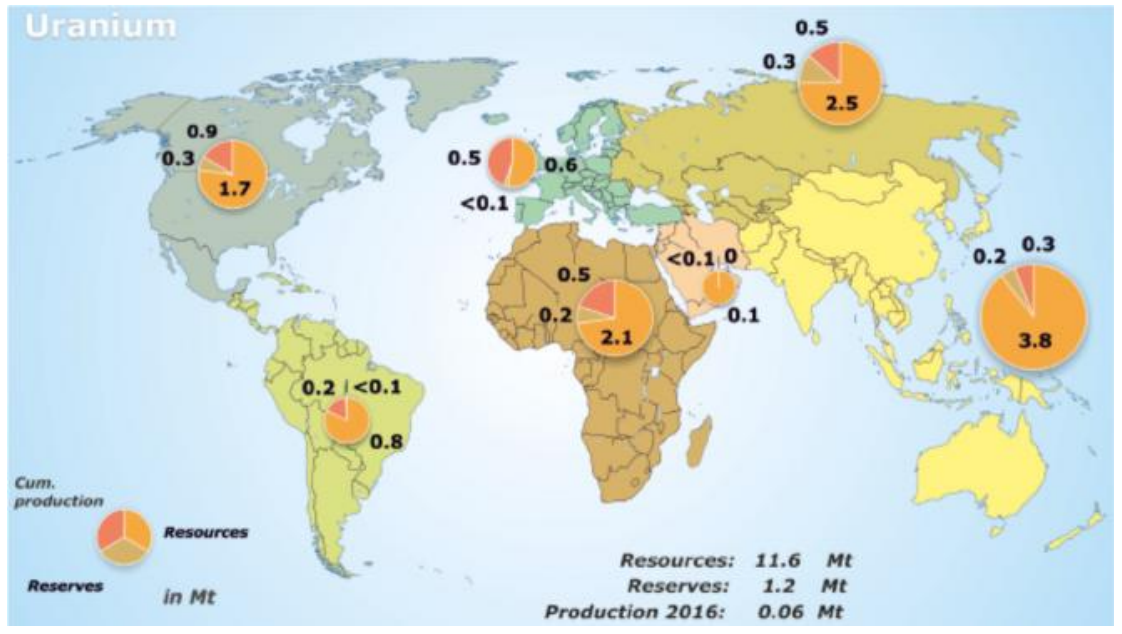

Fig 7. World uranium resources and reserves

Source: [7].

Most of the world's nuclear reactors require enriched fuel. Enrichment is the process of raising the proportion of the uranium 235 isotope from the naturally occurring less than $1 \%$ to about $3.5 \%$ to $5 \%$. To accomplish this, uranium oxide (yellowcake) must be converted into uranium hexafluoride (UF6) in gaseous form. This process requires sophisticated technical equipment and highly specialized expertise since separating uranium-235 from uranium-238 is difficult due to their small difference in mass. Thousands of high speed vertical centrifuges must be used to create commercial quantities. This procedure is one of the main barriers to nuclear proliferation. Some reactors, notably Canadian CANada Deuterium Uranium reactors (CANDUs), use technology that does not require enriched uranium [13]. The thermal efficiency of this design is lower than of competing ones but this is mitigated by lower fuel cost.

Enriched uranium hexafluoride is converted to uranium dioxide which is then heated and placed into fuel assemblies that are a few meters long. A nuclear power plant uses about a hundred thousand times less fuel than a coal plant, e.g. 27 tons of uranium versus 2.5 million tons of coal per year for a typical $1000 \mathrm{MW}$ plant [13].

\section{Why nuclear power}

Currently, three basic forces are used to produce electricity. Gravitational forces causing water flow were first used to drive various machinery such as mills and later hydroelectric power stations. Chemical energy from 
burning of traditional biomass or other fuels, such as coal, oil and natural gas, offered an increase of roughly a million times as much energy as flowing water. Now nuclear fission offers roughly a million times more energy per unit of fuel than can be obtained from burning fossil fuels [14]. The reason for this is found in Einstein's famous $E=m c^{2}$ equation which states that energy obtained in a nuclear reaction equals the mass converted to energy times the speed of light ( $c=299,792,458 \mathrm{~m} / \mathrm{s}$ ) squared or $89,875,517,873,681,764$ (roughly 90 million billion) times the mass that was consumed in the process. The difference in mass is very small but the amount of energy produced is great. Fusion offers still more energy potential due to a greater difference in mass, however, extensive research into harnessing it to produce energy has thus far not produced commercially viable results. Comparison of electricity generation technologies is made in Table 1.

Table 1. Electricity generation technologies

\begin{tabular}{|c|c|c|c|c|c|}
\hline Force & Gravitational & Chemical & $\begin{array}{l}\text { Nuclear } \\
\text { fission }\end{array}$ & $\begin{array}{l}\text { Nuclear } \\
\text { fusion }\end{array}$ & $\begin{array}{l}\text { Wind, solar, } \\
\text { geothermal }\end{array}$ \\
\hline $\begin{array}{l}\text { Existing } \\
\text { technology }\end{array}$ & $\begin{array}{l}\text { Weights, } \\
\text { flowing water }\end{array}$ & $\begin{array}{l}\text { Burning and other } \\
\text { chemical reactions }\end{array}$ & $\begin{array}{l}\text { Fission or } \\
\text { fusion }\end{array}$ & $\begin{array}{l}\text { Hydrogen } \\
\text { bomb }\end{array}$ & $\begin{array}{l}\text { Turbines, } \\
\text { Photovoltaic (PV), } \\
\text { Concentrating solar } \\
\text { power (CSP), } \\
\text { heating }\end{array}$ \\
\hline Fuel use & $\begin{array}{l}\text { None (no fuel is } \\
\text { consumed - it } \\
\text { only changes } \\
\text { location) }\end{array}$ & $\begin{array}{l}\text { Wood (and other } \\
\text { biomass, biogas or } \\
\text { biofuels), waste, } \\
\text { hydrocarbons (coal, } \\
\text { oil, natural gas) }\end{array}$ & $\begin{array}{l}\text { Mainly uranium } \\
\text { but also } \\
\text { plutonium and } \\
\text { other }\end{array}$ & Hydrogen & None \\
\hline $\begin{array}{l}\text { Environmental } \\
\text { concerns }\end{array}$ & $\begin{array}{l}\text { Flooding and } \\
\text { other land and } \\
\text { waterway } \\
\text { degradation }\end{array}$ & $\begin{array}{l}\text { Pollution, including } \\
\text { nitrogen oxides } \\
\left(\mathrm{NO}_{\mathrm{x}}\right) \text {, sulfur oxides } \\
\left(\mathrm{SO}_{\mathrm{x}}\right) \text { and fine dust } \\
\text { particulates (PM10 } \\
\text { and } \mathrm{PM} 2.5) \text {; plus } \\
\text { large } \mathrm{CO}_{2} \text { emissions. }\end{array}$ & $\begin{array}{l}\text { Radioactive } \\
\text { waste from fuel } \\
\text { mining, } \\
\text { processing and } \\
\text { burning; long } \\
\text { term storage } \\
\text { required. }\end{array}$ & None & $\begin{array}{l}\text { Wind: noise from } \\
\text { wind turbines, birds } \\
\text { killed by blades; } \\
\text { geothermal: risk of } \\
\text { ground water } \\
\text { contamination; } \\
\text { solar: none }\end{array}$ \\
\hline $\begin{array}{l}\text { Amount of } \\
\text { energy (relative } \\
\text { to water) }\end{array}$ & 1 (reference) & $\begin{array}{l}\text { million } \\
\mathrm{x} \text { gravitational }\end{array}$ & $\begin{array}{l}\text { million } \\
\mathrm{x} \text { burning }\end{array}$ & $\begin{array}{l}10 \\
x \text { fission }\end{array}$ & $\begin{array}{l}\text { Between gravity } \\
\text { and chemical. }\end{array}$ \\
\hline Sustainability & Indefinite & $\begin{array}{l}\text { Tens to hundreds of } \\
\text { years }\end{array}$ & $\begin{array}{l}\text { Thousands of } \\
\text { years }\end{array}$ & Indefinite & Indefinite \\
\hline
\end{tabular}

Source: Author's

\section{Concerns about nuclear power and technological development}

One of the main advantages of nuclear power is the elimination of $\mathrm{CO}_{2}$ emissions that are one of the main concerns with coal burning and also to a lesser extent natural gas, although natural gas $\mathrm{CO}_{2}$ production is about half of that for coal. The main disadvantages of nuclear power plants are the high construction costs, the generation of radioactive waste and the risk of contamination of the natural environment in the event of a major accident or terrorist attack. In the case of construction of this type of facilities, there are often long delays, with investments going significantly, even several times, over budget due to underestimation of the actual cost. The reason for the increase in construction costs are often technological changes introduced during construction to meet legal regulations in the area of security. There were three main nuclear disasters that deeply influenced the nuclear industry (Table 2).

The first generation of nuclear reactors (I), developed until about 1965, were prototypes to test various technologies. Generation II reactors produced from about 1965 until 1995 are the most common type of reactors in operation today. They were the first commercial light water reactors (LWRs), pressurized water reactors (PWRs) or boiling water reactors (BWRs) and similar Soviet designs (VVERs and RBMKs). 
Table 2. Most influential nuclear disasters

\begin{tabular}{|c|c|c|c|}
\hline Name & Three Mile Island & Chernobyl & Fukushima Daiichi \\
\hline Country & USA & Soviet Union (now Ukraine) & Japan \\
\hline Year & 1979 & 1986 & 2011 \\
\hline Technology & Gen2 1970s (PWR) & Gen2 1960s-1970s (RBMK-1000) & Gen2 1970s (GE Mark-I BWR) \\
\hline Main cause & Stuck valve & Failed steam turbine test & Flooding from tsunami \\
\hline $\begin{array}{l}\text { Loss of life } \\
\text { (estimate) }\end{array}$ & $\begin{array}{l}\text { Direct: none; } \\
\text { indirect: disputed }\end{array}$ & $\begin{array}{l}\text { Official: } 31 \text {; unofficial: 4,000 (WHO } \\
\text { estimate); many more sick }\end{array}$ & $\begin{array}{l}\text { Direct: } 1 \text {; indirect: hundreds (disputed; } \\
\text { compounded by earthquake and } \\
\text { tsunami that killed } 18,500 \text { people) }\end{array}$ \\
\hline $\begin{array}{l}\text { Evacuation } \\
\text { (estimate) }\end{array}$ & 140 thousand & 350 thousand & $150-300$ thousand \\
\hline $\begin{array}{l}\text { Cost } \\
\text { (estimate) }\end{array}$ & 1 billion USD & $\begin{array}{l}700 \text { billion USD (USC Institute for } \\
\text { Global Health estimate) }\end{array}$ & $\begin{array}{l}187 \text { billion USD ( } 2016 \text { Japanese } \\
\text { government estimate) }\end{array}$ \\
\hline $\begin{array}{l}\text { Significant } \\
\text { impacts }\end{array}$ & $\begin{array}{l}\text { - drop in support } \\
\text { for nuclear power }\end{array}$ & $-100,000 \mathrm{~km}^{2}$ of land contaminated & - $20 \mathrm{~km}$ evacuation zone \\
\hline Notes & & $\begin{array}{l}\text { - reactor had no containment } \\
\text { vessel to keep the radioactive } \\
\text { materials from escaping in case of } \\
\text { accident }\end{array}$ & $\begin{array}{l}\text { - soon after, Germany accelerated plans } \\
\text { to close all nuclear power plants by } 2022\end{array}$ \\
\hline
\end{tabular}

Note: both the direct and indirect impacts are estimated and strongly disputed. Source: Author's based on [2, 4, 5, 12-15].

CANDU reactors should be viewed separately due to significantly different design using heavy water $\left(\mathrm{D}_{2} \mathrm{O}-\right.$ water with an extra neutron) for cooling (instead of the normal "light" water used by other reactors). Their efficiency is lower than that of other designs but they have the advantage of being able to use unenriched uranium and other fuels such as plutonium. Nevertheless, they as well as all other generation II reactors require active measures to keep them from melting down in the event of a malfunction. In other words, in the event of a malfunction operators must do something that usually requires a power source, to avoid an accident. This is a significant safety risk since power may be out or access to the reactor or its controls may be difficult.

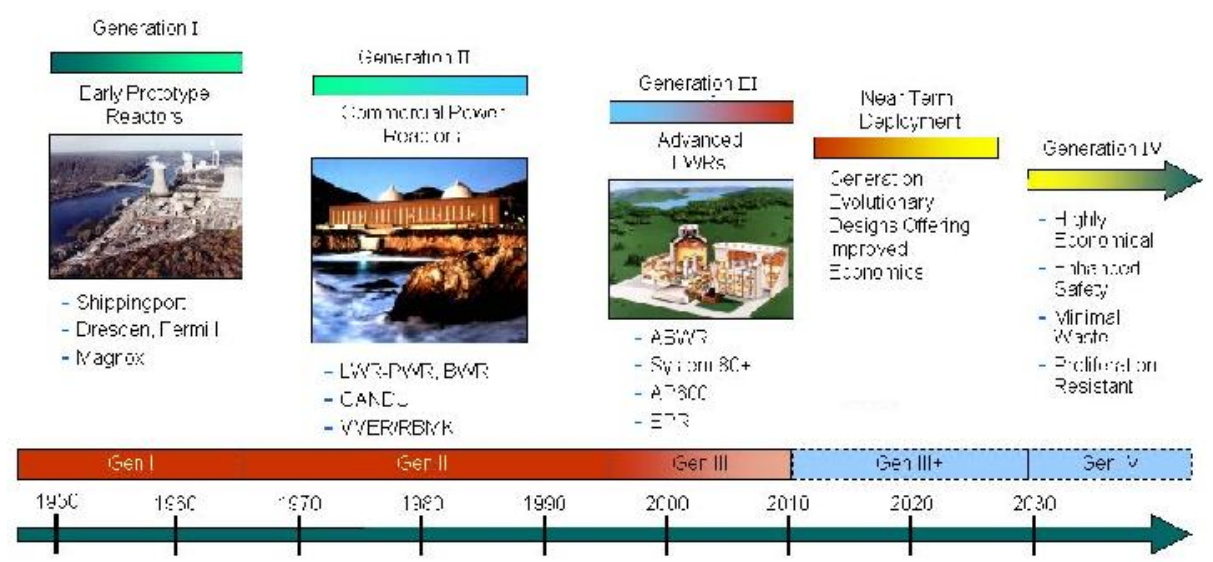

Fig. 8. Nuclear power reactor generations I-IV Source: [16].

Generation III reactors (Figure 8 shows a comparison) were designed using lessons learned from malfunctions and accidents in generation II reactors, especially at Three Miles Island and Chernobyl. They started being introduced around 1995. Their main advantages are as follows (based on [13, 17]):

- Safety and economy:

- More standardized design for each type of reactor to reduce regulatory approval time as well as reduce capital cost and construction time.

- Safety:

- Combination of active and passive safety systems. In the event of a malfunction, passive systems rely on natural forces, such as gravity, convection or materials resistant to high temperatures, to avoid accidents. Thus no active intervention is required for a substantial 
period of time such as 3 days. This gives emergency personnel much more time to fix malfunctions and take other safety precautions.

- Safer core design so that the probability of a core melt accident is reduced by $90 \%$.

- Stronger construction to resist terror attacks, even impact by aircraft.

- Economy:

- Longer operating life: typically 60 years with the possibility of an extension.

- Higher availability; reduced fuel consumption and thus also less radioactive waste.

- Other:

- In some markets such as the EU and US Electric Power Research Institute (EPRI), new reactor designs must be able to follow load over a wide range of demand, such as from $50 \%$ to $100 \%$ of capacity.

- Some new designs are modular to simplify and speed up construction.

Reactors introduced since the mid-1990s are built to withstand even the impact of a large aircraft to significantly reduce the risk of environmental contamination in the event of a terrorist attack. Generation IV reactors are currently in development. They are being designed to offer significant safety, reliability and economic advantages. The Generation IV International Forum (GIF) reviewed 130 reactor concepts and selected six for further research and development, including the Gas-cooled Fast Reactor (GFR), Lead-cooled Fast Reactor (LFR), Molten Salt Reactor (MSR), Supercritical Water-cooled Reactor (SCWR), Sodium-cooled Fast Reactor (SFR) and Very High Temperature Reactor (VHTR). Design testing is expected to take place in the 2020s and commercial deployment in the 2030s. Research is also ongoing to optimize the fuel cycle to minimize fuel use and waste [16-23] and use nuclear fuel for district heating in China with the newly developed Yanlong DHR400 reactor [24]. Small modular reactors are being constructed to make nuclear power production more flexible [25]. Another area of innovation are floating nuclear power stations.

\section{Conclusion}

The article assessed nuclear power development, concerns, advantages and innovations leading to the following conclusions:

- World electricity consumption is growing almost twice as fast as primary energy demand due to lack of substitutes for many applications and the ease in which electricity may be converted to other forms of energy such as mechanical energy to drive machinery and vehicles or heat.

- Despite continuous technological progress, the share of nuclear in the world energy mix is decreasing, especially in countries with highly developed economies.

- World electricity production has almost quadrupled from 1973 to 2016. The share of nuclear power has risen from 3.3\% to about 14\% before the Fukushima Daiichi nuclear disaster in 2011 but has since dropped to $10.4 \%$ in 2016.55 additional nuclear power plants in 18 countries with a total capacity of $56.6 \mathrm{GW}$ (including 11 reactors in China alone) are under construction - all of them are due to start operating by the mid-2020s. It is estimated that the construction of new nuclear power plants will consume USD 1.1 trillion by 2040 , of which $63 \%$ will take place in developing countries.

- Nuclear fission offers roughly one million times more energy per unit of fuel than can be obtained from burning.

- Some reactors, notably Canadian CANDUs, have the advantage of being able to use unenriched uranium and other fuels such as plutonium.

- Generation III reactors were designed using lessons learned from malfunctions and accidents in generation II reactors, especially at Three Miles Island and Chernobyl. They started being introduced around 1995. They offer a more standardized design that features active and passive safety systems, safer reactor design, stronger construction, longer life and reduced fuel consumption.

- Generation IV reactors that are currently being developed feature further safety, reliability and economic advantages. Research is also ongoing in using nuclear reactors for district heating and developing smaller, more flexible modular reactors. A Russian floating reactor became operational in 2018.

Despite significant technological progress, it is still unknown whether future innovations will be sufficient to outweigh the problems with: high capital expenditures and their uncontrolled growth, fears of contaminating the natural environment in the event of a failure or terrorist attack as well as difficulties in fuel and waste 
processing, especially long-term disposal of radioactive waste. However, progress in the construction of Deep Geological Repositories (DGRs) in countries such as Finland, France and Sweden should be noted.

\section{Acknowledgements}

Publication of this article was financed by the AGH University of Science and Technology in Krakow (subsidy for the maintenance of research potential).

\section{References}

[1] BP, Energy Outlook, BP, London 2018.

[2] Michalski M., Optymalizacja decyzji inwestycyjnych w elektroenergetyce, AGH, Kraków, 2012.

[3] International Energy Agency (IEA), Key World Energy Statistics 2018, IEA, Paris, 2018.

[4] Nuclear Energy Agency (NEA), Nuclear Energy Today, NEA, Issy-les-Moulineaux, 2013.

[5] International Energy Agency (IEA), World Energy Outlook 2017, IEA, Paris, 2017.

[6] https://pris.iaea.org, access 2019.01.02.

[7] Bundesanstalt für Geowissenschaften und Rohstoffe (BGR) 2017, Energy Study, BGR, Hannover 2017.

[8] International Atomic Energy Agency (IAEA), Energy, Electricity and Nuclear Power Estimates for the period up to 2050, IAEA, Vienna, 2017.

[9] Nuclear Energy Agency (NEA), Nuclear Energy Data, NEA, Issy-les-Moulineaux, 2017.

[10] Nuclear Energy Agency (NEA), International Atomic Energy Agency (IAEA) 2018, Uranium 2018: Resources, Production and Demand, NEA, IAEA, Boulogne-Billancourt.

[11] Musyoka D., Field R.M., Review of the environmental oversight framework in Kenya, in light of a nuclear power programme, Progress in Nuclear Energy 108 (2018), 89-98.

[12] http://www.ippnw.org, access 2018.09.05.

[13] http://www.world-nuclear.org, access: 2018.09.06.

[14] Dąbrowski M. Energetyka jqdrowa w koegzystencji ze środowiskiem, Polish Physical Society, Warsaw 2011.

[15] Kramer F.J. 2018, Energy scenarios - Exploring disruption and innovation, Energy Research \& Social Science 37, pp. 247-250.

[16] http://www.ne.anl.gov, access 2018.09.07.

[17] http://www.gen-4.org, access 2019.01.05

[18] Wang Q., Li R., He G., Research status of nuclear power: A review (in) Renewable and Sustainable Energy Reviews 90 (2018) 90-96.

[19] Yue Q., He J., Zhi S., Dong H. Fuel cycles optimization of nuclear power industry in China (in) Annals of Nuclear Energy 111 (2018), 635-643.

[20] Handbook of Generation IV Nuclear Reactors, 2016, I.L. Pioro (ed), Elsevier - Woodhead Publishing (WP), Duxford, https://www.gen-4.org/gif/jcms/c_9373/publications.

[21] Pioro, I. and Duffey, R., 2018. Current Status of Electricity Generation in the World and Future of NuclearPower Industry, (pp. 67-114), Chapter 3 in book: Managing Global Warming, an Interface of Technology and Human Issues, T. Letcher (Ed.), Elsevier, London.

[22] Pioro, I. and Duffey, R., 2018. Current and Future Nuclear-Power Reactors and Plants, (pp. 117-197), Chapter 4 in book: Managing Global Warming, an Interface of Technology and Human Issues, T. Letcher (Ed.), Elsevier, London.

[23] http://nuclearengineering.asmedigitalcollection.asme.org/acceptedmanuscripts.aspx, access: 2018.01 .05

[24] http://www.ciae.ac.cn, access 2018.09.04.

[25] Nuclear Energy Agency (NEA), Small Nuclear Reactors, NEA, Issy-les-Moulineaux, 2016.

\section{Units}

GJ gigajoules $=10^{9}$ joules (units of energy)

GW gigawatts $=10^{9}$ watts (units of generating capacity)

Mt million tons

MW megawatts $=10^{6}$ watts

toe ton of oil equivalent; 1 toe $=41.868 \mathrm{GJ}$

TWh terawatt hours $=10^{12} \mathrm{Wh}$ (units of electrical energy) 


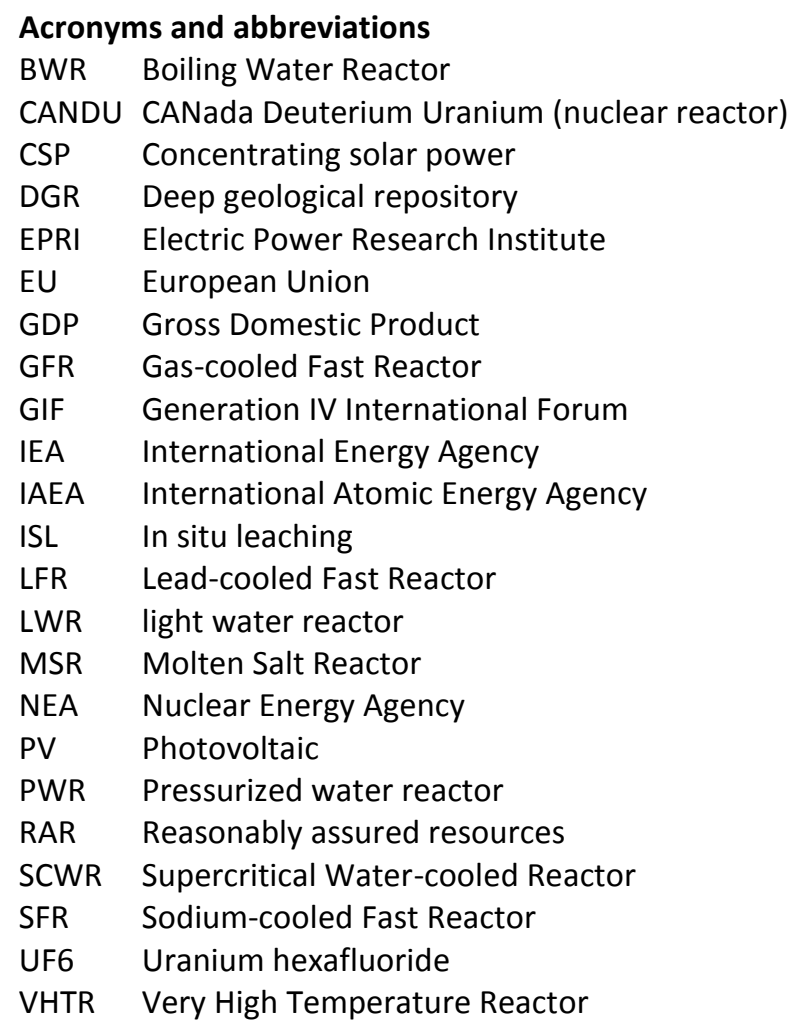




\title{
Anatoliy Bogdanenko \\ Interregional Academy of Personnel Management, Department of Public Administration \\ office 506, 5 Skliarenko str., 04073 Kyiv, Ukraine
}

\section{RESEARCH ON INVESTMENT AND INNOVATION ACTIVITY IN UKRAINE: TRENDS AND PROBLEMS}

\begin{abstract}
In this article, the theoretical identification of concepts and categorical series of state regulation of investmentinnovation processes are investigated; the directions of optimization of the state policy of innovation and investment development management in Ukraine are determined; the organizational and legal principles of the state regulation of development of intellectual potential of the population are substantiated; the areas of development and improvement of the national innovation system as an object of state policy are highlighted and assessed.
\end{abstract}

\section{Key words}

investment processes, innovation processes, state management, Ukraine

\section{Statement of the problem}

The article examines the theoretical aspects of investment activity in Ukraine and abroad, its essence and main problems. The forms of investment relations revealed made it possible to define their specific features. The influence of the level of investments in the development of the economy is estimated and the long-standing need for improvement of financial mechanisms for implementation of investment activity, in particular, based on processes of decentralization of the state authority powers is verified. It determines the current situation in the market of investment activity that shows the importance of searching for new methodological approaches to the formation of sources of financing the economy. One of the main factors slowing the economy in Ukraine down is the shortage of long-term investments. Instead, one of the important stages of development and successful operation of investment activity is the optimization of sources of financing.

\section{Analysis of recent researches and publications.}

The theoretical bases of investment activity were developed in the scientific works of V. Berens, L. Gitman, P. Samuelson, J. Honko, I. A. Blank, A. D. Dibrov, I. Y. Dorosh, M. I. Kysil, M. Y. Kodenska, I. V. Lipsits, O. V. Mertens, A. A. Peresada, G. M. Pidlisetskyi, A. M. Plotnikov, P. S. Rogozhyn, Y. O. Romanenko, P. T. Sabluk, V. P. Savchuk, O. Y. Starikov, T. S. Khachaturov, V. M. Khobta, I. V. Chaplay, V. Y. Shevchuk and others. The project development is a multistage, complex and painstaking process that includes technical, organizational, institutional, management, environmental, commercial, financial and social analysis that is recommended to be considered in the incremental and iterative manner.

Each aspect has its own characteristics that are specific to the economy. The main elements of the project analysis are based on local indicators reflecting the objectives of investment activity projects. At the stage of investment research, the conditions meeting the requirements of investors and end users are substantiated. The organizational analysis substantiates the selection of ways to establish the interaction between participants of the investment project. At the stage of investment research, the project concept reflects the cooperation of the participants' relations. When designing the project strategy, the objectives and tasks of the organizations' participation in the investment project are defined. The organizational analysis is based on the competitive system for the selection of the investment project participants. The selection of participants is determined by the project nature, complexity and scope, number of applicants, requirement for a prompt solution of issues and so on. The social analysis substantiates the consistency of the investment project objective with the public and population groups concerned. At the stage of investment research, the influence of the project on the public interests is determined, the social examination of the investment project is performed. During the social analysis, the impact of the investment project on the change of educational, medical, cultural and transport services of the population of the surrounding area is studied. 
The institutional analysis reveals the basic rules of administration, management, and extent of the assistance of organizational and legal conditions for implementation of the investment project. At the stage of investment research, political, legal and administrative factors (regulations, laws, normative documents) are studied. At the stage of contractual relations, the operating procedure of actions of the investment project participants is established. The institutional analysis reveals the extent of economic freedoms of investors, customers and other participants in terms of selection and implementation of activity strategy and tactics. The institutional analysis serves as a restriction condition for acceptability of the investment project implementation. The management analysis is an audit of potential investment project participants for the creation of a strong project team and its interaction with other project participants. The environmental analysis determines the changes and potential environmental damage caused by the investment project and serves for substantiation of measures for human life support in the future. The commercial analysis assumes the substantiation of the most profitable methods for promotion of products to the end user. At the investment stage, the marketing research is conducted and the national strategy is developed, demand and supply are studied. At the stage of detail design and contractual relations, the interaction with the buyers of products is considered. During the creation and implementation of construction products, the changes in the market conditions are determined and prompt state measures for the organization of the marketing process are taken.

\section{The purpose of the article}

The purpose of this article is the study of theoretical and methodological bases of investment activities, made within the frame of the article, and gives the opportunity to formulate relevant conclusions that have theoretical and practical significance. The article considers the methodology of management of specific and integrated types of risks of investment activity, including planning, identification and risk evaluation.

The article determines the key features of development of the investment activity system directly influencing the formation of financial structure of investment projects in general, among them: simultaneous movement of production and financial investments due to the duality of the real estate economic nature; scale of attraction of investment resources, complexity and flexibility of financing system requiring the development of approaches to the formation of reasonable financial structure of the project at different stages of its formation; uneven cash flows and lack of investment return during all investment cycle, etc.

To achieve the objectives and tasks defined in the article, a complex of interrelated general scientific, interdisciplinary and special methods, in particular, systemic; historical; comparative; dialectical, logical and semantic methods; method of logical generalization; analysis and synthesis; induction, simulation, etc., are used. The use of classification method along with systematized method make it possible to generalize the scientific literature and legal documents.

\section{Presentation of the basic material}

The system of national economy management in any country is carried out by means of main forms, methods and levers for employing economic laws as well as the development of main productive forces, formation of human needs, creation of incentives and alignment of social and economic interests of main social groups. The main subsystems of the entire system of the economic mechanism are government regulation, corporate balanced development and market self-regulation. In modern conditions, government regulation of the economy is the dominant subsystem of the system of economic mechanism. The optimal combination of subsystems and appropriate forms, methods and levers provides a possibility of balanced and proportional development of the national economy.

At the same time, the experience of developed countries confirms that the key role in enabling the innovative development and formation of the national innovation system belongs to the state that establishes strategic objectives, provides resource support, and in particular, budget financing, tax incentives, crediting, etc. [1].

Countries have "assumed" the critical importance of innovations for society and with it an intensive type of economic development. During the "cold war", under conditions of the confrontation between the USSR and USA - the accelerated research in the sphere of armament gave the opportunity to consider the innovations as the indicator of technical ideas, creative abilities and the ability of the country to develop intensively. Today world economic literature notes that the "technological" economy will be and is already being replaced by an 
"informational" economy or knowledge-based economy. In this regard, states mainly concentrate on the creation of strategic plans for the development of territories. As the ratio between production and hightechnology industries changes, the innovation activity of industrial enterprises becomes more intense. Therefore today, innovation-based type of economic development is the ground determining the economic power of a country and its place in the international differentiation of labor [2, p. 62]. This also applies to modern Ukraine that is, science and innovation activity are the main factors of stable economic development and social reliability. The scientific and technical potential of the country is created by efforts of national and technical organizations and due to the world's scientific and technical achievements [3, p. 138].

At the present stage of development of world integration processes in the Ukrainian economy with its rapidly growing scientific and technical needs, the timely and full supply of financial resources for innovation activity is of particular importance [4]. Thus, the need of investments is one of the basic factors of stable functioning of the national economy.

Today, there is no country that would refuse government intervention in the economic processes. For this purpose, states use powerful instruments of influence on economic growth.

Investment and innovation activity is one of the key components of drawing real investments, which can also be represented only by innovation activity or investments of intensive development. Effective investment in the innovation process is the main factor determining economic growth. Such investments provide economic restructuring on a new scientific and technological base and promote the improvement of the country's competitiveness. Innovation activity can be financed due to private investments as the variable nature of public funds are insufficient, while the innovative development of the country requires systematic capital investments.

The purpose of government regulation of investment and innovation processes is to completely ensure the implementation of programs of social development in the social, economic, scientific and technical spheres, as well as provide state protection and investment support.

State regulation of investment activity is aimed at managing not only state investments but also regulation of investment activity conditions and monitoring the actions of all investors and participants of the investment process.

The mechanism of state regulation of investment activity in Ukraine is carried out as follows:

- provision of financial assistance in the form of grants, subsidies, subventions, budget loans for the development of individual regions, industries, manufacturing;

- development of state norms and standards;

- implementation of measures for the development and protection of economic competition;

- denationalization and privatization of property;

- determination of the conditions of use of land, water and other natural resources;

- regulation of pricing policy;

- state expert examination of investment projects;

- other measures [5].

The Law of Ukraine "On Innovation Activity" defines the legal, economic and organizational foundations of state regulation of innovation activity in Ukraine, sets out the forms of stimulation of innovation processes of the state and is aimed at supporting the development of the Ukrainian economy in an innovative way. The main goal of the state innovation policy is to create social, economic, organizational and legal conditions for the effective reproduction, development and use of the country's scientific and technical potential, ensuring the implementation of modern environmentally friendly, safe, energy and resource-saving technologies, production and the realization of new types of competitive products [6].

The Law of Ukraine "On Priority Directions of Innovative Activity in Ukraine" defines legal, economic and organizational principles for the formation and implementation of priority areas of innovative activity in Ukraine. 
The purpose of the law is to provide an innovative model of economic development by concentrating the state resources on priority directions of scientific and technical renewal of production, on increasing of the competitiveness of domestic products in the domestic and foreign markets [7].

The mechanism of state regulation of innovation activity is carried out by:

- identification and support of priority directions of innovation activity;

- formation and implementation of state, sectoral, regional and local innovation programs;

- creation of a regulatory framework and economic mechanisms to support and stimulate innovation activity; protection of the rights and interests of entities of innovation activity;

- financial support for the implementation of innovation projects;

- stimulation of commercial banks and other financial and credit institutions that lend money for the implementation of innovative projects;

- establishment of preferential taxation of entities of innovation activity;

- $\quad$ support the operation and development of a modern innovation infrastructure [2].

The mechanisms of state regulation of investment and innovation processes should flexibly combine all levers, both economic and administrative. Under certain conditions, depending on the strategic changes, the instruments of state influence should also provide for certain tactical changes.

Today, the legislative and regulatory framework for the regulation of investments in Ukraine includes more than 100 different normative documents (laws, orders, decrees, instructions, etc.). Despite a large number of regulatory acts, today, imperfect legislation is one of the main reasons hindering the development of investment activity in Ukraine.

The economic basis of scientific, technical and innovation policy is the state's attitude towards these three spheres of the national economy, to the associations of people engaged in scientific, technical and innovation activities, as well as towards the results of such works. The state's attitude is reflected in the knowledge and understanding of the role and significance of science, products of scientific and technical activity in the state's economic system, as well as the ability to effectively direct all existing and potential opportunities of these spheres to achieve tactical and strategic goals of the state's social and economic policy.

As part of an integrated policy of economic growth, public investment and innovation policies are closely linked and interact with other social and economic policies (industrial, structural, financial etc.).

State investment and innovation policies are implemented largely through other policies of integral parts of social and economic orientation. Therefore, when developing the concepts and mechanisms for implementation of these policies, the consistency and coordination of activity of all social and economic policy subsystems and authorities, the activity of which is aimed at its development and implementation, take an important place. The clear delegation of tasks at all levels of the implementation of social and economic development strategy is required.

State investment and innovation policies have higher priority among other policies in the economic sector, but they are formed and implemented mainly by priorities: branch, technical and technological, scientific, innovation, etc. The investment and innovation priorities depend on the status and priorities of the production sector, and the others - on social priorities and the hierarchy of total human needs that change dynamically.

According to the objectively dependent trend of expanding the scope of authority of regions of Ukraine to the state level and as a result, the state innovation and investment system take on priority importance in the scientific, technical, and IT sectors. The activity of the state in the sectors of science, technology, as well as innovation and investment activity, depends on its interests and capabilities and provides impetus to solve the part of the tasks related to using and development of the scientific and technical, and IT potential of the region. This lessens the duties and responsibility of the regions for finding solutions to these problems [8, p. 118].

It is also necessary to emphasize the high level of influence of the institutional factors formed at the state level have on the investment and innovation policy. The state-level institutional standards can regulate the investment and innovation policy by reducing uncertainty and promoting the coordination and cooperation of participants of these processes. 
Market demand is the essential foundation for innovations. Therefore, innovations should possess novelty both for the whole society and in relation to the particular organization, satisfy market demand, that is, to have market potential as an indicator of operating efficiency of the enterprise and realization of its innovative potential.

A common feature is that all EU countries promote the provision of incentives concerning investments into the development of innovative technologies and research and development (R\&D). These incentives include granting credit on preferential terms and reimbursement of expenses for the creation of new technologies from the state budget. In general, these preferences include research and development support in three directions: fundamental research, production research and commercial development. The maximum share of their budget support amounts to 100, 50 and 20 percent, respectively [9]. EU countries apply special incentive innovations and preferential corporate taxes. In particular, Great Britain maintains a low level of taxation for corporations, considering it is a powerful incentive for technological initiatives involving risk.

The low rates of basic taxes in Germany, Spain and Italy are supplemented by special incentive systems for implementation of risk projects. In France, another combination is applied: high taxes for all and other special incentives in the innovative business. Special attention is paid to support of private innovative solutions and broad involvement of small companies in the mentioned process.

This activity also holds a central place to the Forum of Innovation Regions (FIR) and Innovation Relay Centers (IRC).

A special role is played in the regulation of the EU investment complex by special agencies who promote foreign investments. These institutions are responsible for providing information and planning the investment activity, carrying out marketing and advertising initiatives, organizing the negotiations and presenting the incentive packages for investors. The investment agencies grant the investors permission for their activities, settle any conflicts and facilitate the accelerated implementation of the investment projects. Their branches are in many countries worldwide.

Each EU country has a multiple system of investment institutions.

There are special rules for state assistance for certain competition-sensitive economic sectors (ferrous metallurgy, coal mining, textile industry, shipbuilding and automotive industry, manufacture of synthetic fibers) and quickly growing industries (telecommunications, computer technologies). It is assumed that this assistance may also include direct government subsidies. The purpose of the specified assistance is to promote the competitiveness of industries and acceleration of development and implementation of modern technologies.

As a result of joint government decisions of the EU member states, a number of institutions providing direct support to the innovation process were formed in Europe: European Investment Bank, European Investment Fund, Initial Capital and Eurotex Capital projects, as well as a special program for small business support [10, $p$. $156]$.

Financial assistance to the enterprises and the entire sectors from the EU centralized funds, combined with national support for each individual EU country is one of the main instruments of the EU investment policy. At the same time, the European Commission requires strict reporting on the use of assistance from the member countries and individual enterprises. Economic sanctions are applied to countries that misuse assistance for other than the intended purpose.

A key element of the EU investment and innovation system is the "Framework Programs for Scientific and Technological Development", which is the main instrument for the implementation of the EU scientific and research policy. HORIZON 2020, the Eighth Framework Program (FP8) which is still operating today after its inception on December 31, 2020.

The European Union's economic policy directs special attention to the development of small and medium-sized enterprises (SME), which play a key role in the European economy. 
One of the effective mechanisms to promote the development of innovative technologies in the EU is technological development centers - technological parks. The European model of the functioning of technological parks is characterized by significant state economic and organizational support, broad regional cooperation as well as elaborate programs and business plans, which enables qualitative and efficient management of development.

European technology parks tend to rely on large research centers and provide a kind of a bridge for technology transfer between the scientific and industrial sectors. In Europe, clients of technological parks are comprised of both state and privately owned enterprises.

The states providing the most part of financing for technology parks are; Great Britain - 62\%, Germany - 78\%, France - 50\%, Netherlands - about 70\%, and Belgium - almost $100 \%$.

The European Union pays significant attention to cross-border cluster technological cooperation. One of the best known cross-border clusters is Biovalley, the biopharmaceutical cluster established in 1996 in the valley of Upper Rhine river (territory of France, Switzerland and Germany). About 10\% of the total population of this region are involved in the biopharmaceutical industry which includes well-known scientific institutions (universities, research centers, headquarters of well-known global pharmaceutical companies such as Novartis, Roche, Siba, branches of large pharmaceutical companies such as Johnson \& Johnson, Pfizer, Sanofi-Aventis). Other well-known cross-border clusters are: Medicon Valley (territory at the border of Denmark and Sweden around Øresund strait); Biotechnology cluster ( Øresund region, Denmark - Sweden); German-Dutch crossborder cluster (Twente); German-Dutch network of regional clusters of suppliers, technical agencies and innovation institutions around transnational corporations Oce and Nedcar (Venlo), Dommel Valley (Belgium and Netherlands) is also equally well known [11, p. 64].

Global experience shows the ambiguity of PTT influence on the economic development of recipient countries that are associated with the possibility of negative effects as a result of the implementation of investment strategies by foreign investors that may be inconsistent with national interests of the country [12]. The destruction of the fundamental base for ensuring structural reforms in the economy on innovative principles is an extremely ominous trend. The domestic industry has a significant innovative potential capable to ensure the structural transformation of the national economy and provide a high level of scientific and technological development for the country as a whole. At the same time, the productive capacity reserves that were not used during the crisis period and favorable external economic conditions still remained the prevailing sources of growth in Ukrainian industry.

Considering leading world trends, the necessity of inclusion of Ukraine in the world economy based on sovereign partnership and mutual benefit is an objective prerequisite for further innovation development of the country. This is the reason for the questions of determining the place of Ukraine in the structure of the world economy today and in the future are placed on the agenda.

For example, in 2012, the German government approved an action plan called High-Tech Strategy 2020, aimed at securing Germany as a leading supplier of scientific and technical solutions in such spheres as climate and energetics, health and nutrition, mobility, safety and communications [13].

The development of systems for management of competitiveness of microeconomic systems is also impossible without considering the specified factors. In developed countries, understanding the role of innovations by business led to an increase in the volume of non-state financing of science and increase in innovation activity of enterprises and corporations (50-80\% of the total). The sales of companies belonging to the top 10 world leaders in the sphere of innovation activity grow annually by $45-54 \%$, and the profitability of sales is at a level of $70 \%$ [14].

Modern Ukraine has little competitive position in the world markets in the sphere of innovation. The deep decline in industrial production in general and in knowledge-based industries of investment, in particular, leads to the degradation and deindustrialization of the national economy. The industrial sector share in GDP structure is being reduced steadily. For many years, the role of the processing industry in creating the country's GDP has decreased, indicating signs of economic decline and technological backwardness. Raw materials extraction productions, as well as low-tech productions, prevail in the structure of the industry. The same holds 
true in world markets for industrial goods - Ukraine is represented mainly by raw materials and low-tech products.

Against the background of declining total export revenues, the share of agricultural products is growing. It should be noted that the basis of agricultural export is still the export of raw materials, namely, plant products - wheat, corn, barley and soybeans [15].

Operationally, the competition in the world markets for goods and services has two dimensions:

1. Commodities and economics

2. Technological

The commodity and economic dimension of the external trade of Ukraine can be characterized as follows (Table 1):

Table 1. Key indicators of the external trade

\begin{tabular}{|c|c|c|c|c|c|c|c|c|}
\hline & \multicolumn{4}{|c|}{ Export } & \multicolumn{4}{|c|}{ Import } \\
\hline & \multicolumn{2}{|c|}{2015} & \multicolumn{2}{|c|}{2016} & \multicolumn{2}{|c|}{2015} & \multicolumn{2}{|c|}{2016} \\
\hline & $\begin{array}{c}\text { million U.S. } \\
\text { dollars }\end{array}$ & $\%$ & $\begin{array}{c}\text { million U.S. } \\
\text { dollars }\end{array}$ & $\%$ & $\begin{array}{c}\text { million U.S. } \\
\text { dollars }\end{array}$ & $\%$ & $\begin{array}{c}\text { million U.S. } \\
\text { dollars }\end{array}$ & $\%$ \\
\hline Total & 35420 & 100 & $\begin{array}{c}33571 \\
(94,8 \%)\end{array}$ & 100 & 38875 & 100 & $\begin{array}{c}40364 \\
(103.8 \%)\end{array}$ & 100 \\
\hline $\begin{array}{l}\text { CIS } \\
\text { countries }\end{array}$ & 7729 & 21,8 & $\begin{array}{c}5961 \\
(77,1 \%)\end{array}$ & 17,8 & 11880 & 30,6 & $\begin{array}{c}10010 \\
(81.4 \%)\end{array}$ & 24,8 \\
\hline $\begin{array}{l}\text { including } \\
\text { the Russian } \\
\text { Federation }\end{array}$ & 4200 & 11,9 & $\begin{array}{c}3117 \\
(74,2 \%)\end{array}$ & 9,3 & 7420 & 19,1 & $\begin{array}{c}5107 \\
(68.8 \%)\end{array}$ & 12,7 \\
\hline EU & 10447 & 29,5 & $\begin{array}{c}10700 \\
(102,4 \%)\end{array}$ & 31,9 & 13252 & 34,1 & $\begin{array}{c}14877 \\
(112.3 \%)\end{array}$ & 36,9 \\
\hline Europe & 10619 & 30,0 & $\begin{array}{c}10951 \\
(103,1 \%)\end{array}$ & 32,6 & 14500 & 37,3 & $\begin{array}{c}16068 \\
(110.8 \%)\end{array}$ & 39,8 \\
\hline Asia & 12275 & 34,7 & $\begin{array}{c}11734 \\
(95,6 \%)\end{array}$ & 35,0 & 6638 & 17,1 & $\begin{array}{c}8178 \\
(123.2 \%)\end{array}$ & 20,3 \\
\hline America & 762 & 2,2 & $\begin{array}{c}719 \\
(94,4 \%)\end{array}$ & 2,1 & 2048 & 5,3 & $\begin{array}{c}2322 \\
(113.4 \%)\end{array}$ & 5,8 \\
\hline $\begin{array}{l}\text { Including } \\
\text { USA }\end{array}$ & 462 & 1,3 & $\begin{array}{c}416 \\
(90,2 \%)\end{array}$ & 1,2 & 1396 & 3,6 & $\begin{array}{c}1596 \\
(114.3 \%)\end{array}$ & 4,0 \\
\hline Africa & 3755 & 10,6 & $\begin{array}{c}3850 \\
(102,5 \%)\end{array}$ & 11,5 & 444 & 1,1 & $\begin{array}{c}424 \\
(95.5 \%) \\
\end{array}$ & 1,1 \\
\hline Australia & 14 & 0,04 & $\begin{array}{c}18 \\
(130,3 \%)\end{array}$ & 0,05 & 162 & 0,42 & $\begin{array}{c}116 \\
(71.3 \%)\end{array}$ & 0,29 \\
\hline
\end{tabular}

Source: UNCTAD, Key indicators and trends in international trade, 2016

Ukraine must overcome a considerable gap on the level of the innovation activity of enterprises as compared to the developed world countries, especially EU countries.

The sector of information and communication technologies (ICT) in Ukraine is a branch of the national economy that is developing dynamically. According to the State Statistics Committee, the share of information and communication technologies in the GDP was $1.42 \%$ in 2014. The main indicators of development show a positive dynamics in the number of enterprises, the number of employees and the volume of sales of information and communication technologies subsectors [16].

Breakthrough technology as an integral unity of material resources, ideas and original management solutions played a structure-making role in the management systems of economic development of these countries. Its characteristics are defined by the objective and directness of action. 
The organizational framework provides the ranking, evaluation and selection of the priority of scientific and technical programs along with complex coordination of organizational and socio-economic measures.

The formation of an organizational structure requires the creation of a single authority in Ukraine, which would be responsible for the coordination of works in the selection of strategic directions of innovation and technological breakthrough as well as the definition of promising enterprises and productions.

The functional framework ensures coordination and implementation of all stages of the innovation process from planning (design) to market consumption of the innovative product. In total, three frameworks of the innovation module management system provide monitoring; identification of priority directions, technology of innovation breakthrough, implementation and control of the implementation of breakthrough strategy up to the world level of competitiveness.

Analysis and generalization of world experience of incorporating advanced technologies into the mechanisms of synthesis of national competitiveness control systems is evidence of their immediate effect and significant performance. The Second World War had a devastating impact on the economy of Japan, but in 1968, that is, 20 years after the war, the country took third place in the world after the USA and the USSR in terms of gross national product. The German government, which implemented breakthrough reforms of L. Erhard, needed only 12 years to triple the country's gross domestic product (GDP) from 1950-1962. [17, P. 35].

A modern example of the use of breakthrough technologies and the investment and innovation breakthrough module for achieving a world level of competitiveness by a particular region is the creation of a technology park in Kechnec village of Košice Region in Slovakia.

Slovakia and Ukraine have very similar pasts. Ukraine's independence was proclaimed in 1993, but Slovakia overcame most of the difficult process of transition from a centrally planned economy to a market economy and was able to shift to the western market in a very short time (2002-2005). It is currently an industrial and agricultural country, which occupies second place (after Poland) in economic growth among EU countries.

According to a study by the German Chamber of Commerce, about half of German investors see Slovakia as the best place for investments. Among the countries of Central Europe, Slovakia has gradually become a leader in attracting direct foreign investment in the automotive industry

According to the recommendations of the European Commission on the elimination of regional differences, Slovakia pays special attention to the construction of technology parks (an element of innovation infrastructure), especially in Eastern Slovakia, where the social and economic situation is much worse in comparison with one of the more highly developed EU regions. In developed countries, technology parks, universities-incubators, technopolises and diversified scientific zones are becoming more common. Each of them is a powerful scientific and technical complex that processes innovative ideas and projects that are rapidly introducing innovations.

One prime example is the technology park in Kechnec, which was prepared for the attraction of investors in Slovakia in regard to the fulfillment of all conditions that are necessary for entrepreneurs. Nineteen companies (15 foreign and 4 domestic ) are located in the technology park in Kechnec [11]. Most of the investment resources attracted to the technology park are from the technological sectors of the manufacturing industry [18].

Today there are 71 industrial parks operating in Slovakia connected with the following industries: automobile manufacturing, electronics, engineering, chemical industry, pharmaceuticals, information technology.

Among the largest new enterprises in Slovakia are Samsung Electronics (electronics), Sony (electronics), Mondi Business Paper (paper), Hydro Aluminium (production of aluminium) and Whirlpool (household appliances).

Slovakia's example shows that the use of management technologies of an economic breakthrough in an attractive investment climate makes it possible to make a technological "leap" and increase the competitiveness of the national economy in conditions of extremely limited financial and time resources. 
Intellectual potential represents individuals' set of abilities, creative talents, skills and motivations as well as their educational, ethical and cultural level that enable them to use intellectual means to learn and create new knowledge, which is suitable for application in a particular sphere of social reproduction, contributes to the growth of productivity and production efficiency and thereby influences the growth of income of an individual in the future [19, p. 292].

The development of intellectual potential is a priority for the state, as in the present conditions neither wealth of subsoil nor fertile lands or ideal climate, or tourism attractiveness can be compared with the power and social importance of the potential of the human mind.

Human capital is the basis for the formation of an innovative type of development in Ukraine, which is based on intellectual and information technologies of production.

At the same time, the innovative capital of the enterprise should take into account the financial, intellectual, organizational, management, information and methodical potential of the enterprise, which, in turn, will affect the motivation of labor, the culture of production, creating favorable conditions for changes in social relations both in the state and for the enterprises in particular.

The scientific and technical factors influence the level of novelty and the update rate of the product, as well as improvement of technical means and technologies. Due to the negative trends of the transition period, scientific production in Ukraine almost stopped - compared to the Soviet era scientific and technical works have reduced more than 10 times.

Primarily, the economic factors determine the level of development of the labor market. This is why society's intellectual potential is mainly recovered through the labor market.

Legal factors characterize the legislation of Ukraine concerning legal support of the intellectual economy. The scope of intellectual property is regulated by the following basic laws: "On Copyright and Related Rights", "On Protection of Rights to Marks for Goods and Services", "On Scientific and Technical Information". The most important problem of legal support and regulation of intellectual property is the ineffectiveness of legislative acts and the weak implementation of the proclamation of the orientation to the innovative development model in Ukraine.

The social and cultural factors in the context of the formation of a knowledge-based economy are revealed in the trends of development of education and science.

The organizational factors solve a fundamental problem: the existence of applied science outside of the production sector. Today, the first financial and industrial groups are being formed, which are based on mutually beneficial investment relations between science and business.

The environmental factors are characterized by an increase of the strength of their effect in modern conditions of social production. Most often they act as limitations on the use of raw materials [20, p. 60-62].

The main factors that negatively affect the formation and development of Ukraine's intellectual potential today are:

- poorly developed innovation infrastructure;

- lack of incentives for innovative projects;

- insufficient funding of science;

- underdeveloped intellectual property market;

- $\quad$ elderly age of most scientists.

The modernization of public administration with regard to human development requires consistent action to fulfill international obligations and meet national needs in this area. First of all, it requires the provision of legal status to Eighth framework (FP8), which was adopted by Ukraine, Horizon 2020, their development and implementation at the state and regional levels; overcoming differentiation of human development at the regional level; development of a system of state social guarantees and social standards, ensuring the achievement of social equality and equal starting opportunities for education, health service, employment; 
creation of equal conditions of access to social services, social and housing services; ensuring the decentralization of social policy; justification and qualitative differentiation of social functions of the state and regions in respect of powers, duties and responsibilities for human and social development; increase of efficiency of activity of authorities of state and regional government concerning the formation and implementation of social policies; improving the assessment of activity of bodies of state and regional authorities in relation to human and social development; maintaining balance between development of market economy and ensuring social justice through fiscal, tax, pricing policy as well as credit and monetary regulation; conformation of social and labor legislation with the requirements of effective social control; ensuring a balance between reforming the economic mechanism and reforms in the social sphere, creation of institutional conditions for ensuring the transfer of knowledge from the university environment to the industry. For example, there is a need for conditions that will enable enterprises to use ideas and technologies, which are developed in universities, under license:

- ensure closer communication between the teaching and research staff of universities and employees of specific companies, so that researchers have a more realistic idea of the problems faced by the industry and practitioners have access to scientific knowledge. This can be achieved by using the Cape town approach, according to which the teaching staff of the University works closely with managerspractitioners;

- enterprises should not strive to be experts in everything, they can choose a fairly narrow industry, in which they will have possibilities for competitive development. And of course, these small companies should closely cooperate with universities and research departments of large enterprises, making a contribution to the common cause with their knowledge of the sphere where many are high-class specialists [21].

The mass communication system, as a component of influential factors, should also manifest itself with a significant effect in the development of the intellectual potential of the employed population. Creative work differs from non-creative work mainly in that it does not allow to churn out the production of standard items: the product of creative work exists in one copy and is marked by the individuality of the manufacturer and his worldview.

With the advent of the Internet, mobile communication itself has turned into a "production pipeline": the structure of professional mass communication includes elements of the production process associated with virtualization, remote control, propaganda, manipulation of people's actions both in everyday life and in the process of their professional activities. Therefore, the consideration of communication as a production activity means that it should be dealt with as an element of the employment process, which proceeds with the use of certain technologies and it is reasonable to consider those employed as an intellectualized subject of communicative production [22, p. 195].

The state government must create a favorable political, legislative, social and economic environment in close interaction with business entities.

Ensuring the commercial implementation of the results of intellectual activity should be carried out through the formation of special complex structures that would become direct participants in the process of creating a legal object of intellectual property, carry out an expert assessment of its commercial attractiveness, including an indicative assessment of the value of intellectual property rights, study the market situation and provide effective marketing and financial support for innovative developments [23, p.54].

Therefore, in Ukraine, it is necessary to create a mechanism to support insurance companies that specialize in insurance of innovative risks: simplification of taxation of such companies, provision of loans on favorable terms, creation of state insurance companies that would specialize in insurance of innovative risks.

The main task of the innovation market is to solve the problems associated with the lack of finance, personnel and information regarding innovation systems, as well as the creation of a mechanism for insurance of innovative risks.

Currently, only the separate elements of the national innovation system in Ukraine are established and operate, the cycles of the innovation process are poorly coordinated with each other and not linked, so the returns from innovation activities remain low. 
The effective integration of Ukraine into the global scientific and technological sphere is possible only on the basis of the development of the innovative economy in conjunction with following current trends of global innovation development. In this context, it is reasonable to mention the tendency of an increase of contradictions, imbalances and asymmetries in the global innovation sphere, of gradually changing its functional and structural design. These contradictions include:

- Contradictions between national and global interests. The interdependence of subjects of different national innovation systems is increasing leading to the formation of global innovation networks with appropriate mechanisms for self-organization and development. The global processes cause the de facto cancellation of certain state functions and the strengthening of others aimed at the formation of own stable and balanced economic development. The contradiction occurs between the objective processes of globalization of innovation processes with all its inherent features and the desire of national governments to preserve the national state economic system.

- Increased international competition. Competition often intensifies on world markets leading to unfair competition, the emergence of new organizations' forms of business organization (in order to obtain additional competitive advantages, firms create strategic alliances, resort to the processes of merger and acquisition, representatives of small and medium businesses join subcontracts, outsourcing, contract works), whereby a more complex system of non-market relations is formed.

- Current conditions and features of global competition require all market subjects to make advanced organizational and structural changes, however, the existing regulatory mechanisms do not correspond to these processes, the system of institutional support of global innovation development is lagging behind the scale and dynamics of global transformations.

- There are two contradictory trends in the development of the global technology market today. The first is the desire of technology owners to keep trade secrets and full rights to intellectual property. The second is in an attempt to commercialize the technology, including through entering the world market.

The existing asymmetries and contradictions of the global integration of the national innovation system, on the one hand, and the failure of the global market fundamentalism to neutralize these asymmetries, on the other, make it necessary to create an appropriate global regulatory system that would ensure the formation of effective mechanisms for the harmonization of national economic interests and policies, ensure the protection of technology owners, the introduction and compliance of countries with generally accepted norms and rules of technological exchange, as well as the adoption of sanctions against those, who violate these rules.

The integration of the national innovation system is an objective process, because the nature of information of the modern stage of civilizational evolution and the formation of the fifth and sixth technological modes make it impossible for any state to compete successfully in the high and medium technology sectors not only on external, but also internal markets without entering the spheres of information, science and technology.

Taking into account the likely global technological changes to come (the beginning of a new technological wave or its significant delay with the focus on large-scale replication of improving innovations) and possible options for the transformation of the national innovation system, three basic scenarios for the development of innovation processes in Ukraine can be considered: progressive, moderate and inertial. The progressive scenario provides for the intensive development of the national innovation system and its forced integration into the global economy with the implementation of the postindustrial development model. This scenario is the most difficult but also the most promising in terms of ensuring the long-term competitiveness of the state.

The main criteria for the implementation of such a strategy in the context of economic security are as follows: a share of the growth of GDP is distributed to higher education, science and science-driven sectors of the economy; increase in the growth of the intellectual services sector in the economy; growth in the volume of funding of research and development work, increase of the number of researchers and organizations engaged in research and development; growth in the volume of scientific and technical works performed and their share of the GDP; growth of the average education level of the economically active population of Ukraine, as well as the number of workers with higher education and mobility of workers of intellectual work; growth of the quality of education, the formation of a market of educational services and training; ensuring the growth rate of average incomes of workers in the sector of intellectual activity. It is necessary to work on the creation of such a strategy and its practical implementation today! 
The necessity of Ukraine's integration into the European and world competitive environment determines the need to create an innovative development model, in which the main source of economic growth is the results of intellectual activity and their practical application. This is the generally recognized way which not only highly developed states but also states undergoing transformation use to develop an economy based on knowledge.

This approach should provide for: concentration of resources on the priority areas of creating conditions for the growth of intellectual potential and strengthening of its role in ensuring economic security; unity of educational and scientific processes and their focus on society's economic, social, intellectual and spiritual development; optimal combination of government regulation and management of intellectual activity in higher educational institutions, scientific institutions, enterprises and organizations [24, p. 26].

At the turn of the millennium, Ukraine was one of the leading countries of the world in terms of the number of researchers, had a relatively high human development index, and its index of the education level of the population even exceeded the average index of Eastern Europe and the CIS. However, an analysis of statistical sources shows that there is a steady trend of reduction in the number of scientists and organizations who perform research and development works.

The main reasons for the decrease in the number of researchers in Ukraine are: the processes of emigration of highly qualified specialists; lack of replenishment of scientific personnel staff with younger staff; lack of prospects for the implementation of own ideas due to material, economic and other reasons in the state; a large discrepancy between commercial and state salaries of creative workers [25, p 48].

Innovation activity is the purposeful activity of business entities regarding the design, creation, development and production of new types of equipment, subjects of labor, intellectual property (patents, licenses, etc.), technologies, as well as the introduction of more advanced forms of labor organization and production management. In the conditions of effective interaction of all elements of the innovation system, the main factors of innovation activity at the macro level are the growth rates of public spending on the development of science and education, rational innovation policy of the state, stimulating tax, credit and depreciation policy $[26$, C. 48].

In Ukraine, there is a decrease in the innovative activity of enterprises, which indicates primarily the limited domestic effective demand for innovation and the lack of effective incentives for innovation activity to take place.

One of the significant factors hindering innovation activity for enterprises is the long payback period for innovations, as a condition of instability this means additional risks. Therefore, enterprises refuse to introduce innovations in production due to the high economic risk which in turn hinders the innovative development of the entire country.

In accordance with the current legislation, namely, the Law of Ukraine "On Scientific and Scientific and Technical Activity", innovation development in Ukraine is provided at the expense of financing from various sources. In particular, Article 34 of this law establishes that budget financing is one of the main instruments for the implementation of state policy in the field of scientific and technical activities [27]. The state must provide budget financing of scientific and technical activities (other than defense expenditures) of at least $1.7 \%$ of Ukraine's GDP. However, the actual amount of financing of scientific and technical activities from the state budget decrease yearly.

In order to solve the problems of increasing the country's innovation potential, it is necessary to identify the main tasks and potential opportunities for innovation in Ukraine.

Taking into account the above mentioned factors, one of the main needed directions in the process of Ukraine's transition to innovation is an improvement of the investment climate in Ukraine and stimulation of investment in the development of innovative products and technologies [28, p. 23].

The search for external sources of financing not only for innovation but also for other spheres of the economy is the main feature of the current stage of Ukraine's development [29, p. 162]. By attracting investments to 
production, the volume of production is increased, the funds are modernized, and within the country it means that the level of market competition, the balance of payments, and the investment infrastructure are developing.

Dynamics of direct foreign investments depends on the attractiveness for investment of the country as a whole, as well as its individual regions. As for state support for the development of the innovation sector, statistics show there is a low level of state financing of innovation activity.

In Ukraine today, in addition to external investors, there are also potential domestic investors. However, for wider involvement of domestic investment, mechanisms are needed to attract shadow capital. In addition, credit resources, property rights and intangible assets, loans, collateral and other types of financial resources should be included in the financial turnover, since the more innovative investments there will be, the more effective the innovation system will be. Solving these problems requires the development of state programs, the introduction of financial motivation and the development of an appropriate innovation infrastructure.

Domestic investment is an attractive potential source of income. To increase such investment, it is expedient to develop rational terms and conditions for taxation of small and medium businesses and grant benefits for conducting their activities, which in turn, will reduce the level of the so called "black economy".

The creation of "regional monopolies" is a negative consequence for small and medium-sized businesses, therefore it is important to increase the efficiency of the activity of Ukraine's antitrust authorities. The low investment attractiveness of Ukraine's regions in turn leads to a low level of investment in its economy.

Every effort should be made to create a favorable investment climate to attract both domestic and foreign investments. Unfortunately, the investment rating of the regions of Ukraine indicates the low professional level of state management of investment activity [30, p. 37].

The Ukrainian economy has been strongly influenced by the global financial crisis. First of all it caused a liquidity crisis in the banking sector, as foreign banks turned their programs down. In addition, the National Bank of Ukraine has increased requirements for reserving of resources, which led to an increase in the cost of loans. As a result, the growth rates of mortgage loans have fallen below the growth rates of the total loan portfolio. There was a significant fall in the stock market and also due to the financial crisis there was a withdrawal of foreign investors from Ukraine.

The separation of savings into organized and unorganized components (on deposit and directly from the population) may be insignificant in developed countries, where the black economy is relatively small. In countries with a transformational economy, the volume of unorganized savings is quite large. These funds, most often convertible into US dollars or euros, are essentially withdrawn from economic circulation. In Ukraine, the amount of free money in the hands of the population is estimated to be as much as 50 billion dollars. The availability of such a large cash array was made possible by the uncertainty of the economic situation, the lack of effective tools for attracting private investment, and in this case, a lack of experience [31, p. 132].

Stabilization of Ukraine's economy requires intensified attention to the regulation of investment processes in the regions. At the regional level, it is easier to improve the investment environment and ensure competitiveness as a factor of investment activity.

The lack of domestic funds to solve the tasks of stabilization of the economy requires the attraction of foreign capital, primarily direct foreign investment. World practice shows that the direct investment is a key element in countries' economic development, therefore contributing to the strengthening of the economic complex, as well as an increase in restructuring of scientific and technological potential.

The need to stimulate the inflow of foreign investment by providing them with preferential conditions is a serious problem. Concurrently, it is necessary to strive for the creation of a favorable investment environment not only for foreign investors but for domestic investors as well. 
The effective use and ability to draw foreign investment requires improvement of government regulation. First of all, it is necessary to clearly define and delineate the powers of the objects of government regulation in this sphere in order to coordinate their activities and avoid duplication of efforts and oversight.

It is not attractive for foreign investors to see there is almost no domestic investment in production development. The attraction of foreign investments should be carried out taking into account the goals and objectives of the state programs of structural reorientation of production, target programs of inter-sectoral and sectoral development and conversion and development of export potential. It is also necessary to take into account the processes of internal and external cooperation of products for industrial purposes as well as the privatization of state enterprises with the involvement of foreign capital. The expediency of this approach is confirmed not only by foreign experts but also by the experience of countries such as Japan, where the purchase and use of foreign licenses to a large extent contributed to its social and economic development. The economic conditions should be created for the intensification of investment activities at the national level through the use of primarily financial and economic methods of investment control and stimulation which are typical for the market economy [32, p. 356].

These methods include:

- control of tax rates;

- refinancing;

- establishment of norms of mandatory reserves in National Bank of Ukraine;

- stabilization of the exchange rate;

- reduction/increase of customs duties and the like.

The methods of economic control also include subsidizing of interest on loans to finance investment. This will meet the priorities of regional investment policy and promote co-financing from public and private investment sources.

In addition, in the context of insufficient budgetary funding of the scientific and technical sphere, the need to implement extra-budgetary incentives for scientific and technological progress is becoming ever more necessary. Thus, an effective scheme for financing of innovation activities could be a network of specialized non-bank public financial and credit institutions in various sectors of the economy and separate regions for providing credit for innovation projects. The difference in the nature of the economic problems faced by certain regions also leads to the need for different approaches to their individual solutions.

Accordingly, the state innovation and investment policy should be formed taking into account regional investment programs. As the investments included in the state program will be implemented, objects will be built on certain territories of specific regions, the economic interests of which should be fully taken into account. Taking into account these interests may be ensured through joint equity financing from state and regional sources and the provision of preferential centralized investment loans under the guarantees of local banks [33].

Thus, innovation and investment potential influence a number of different factors that may contribute or hinder innovation and investment activities.

For the investment and innovation strategy, not only the goals but also means of their achievement (that is, the availability of required potential) are the important components.. Investment resources include own and borrowed funds. The means, which are necessary for the implementation of innovation strategy are the availability of required productive potential, manpower, information and market potential.

Competitive (business) strategies are subject to corporate policy, they indicate the ways of achieving of the chosen direction by each strategic business unit and present a plan of winning of strong long-term competitive positions (advantages). These strategies are also called business strategies or competitiveness strategies.

A prerequisite for the development of an effective competitiveness strategy is the definition of the strategic nature and boundaries of the business by the strategist. 
To determine the boundaries of business interests within the frame of the development of the competitive strategy of the enterprise, as a rule it is necessary to clearly identify and investigate the following factors:

- The needs of consumers.

- Segments of consumers, that is, to decide on the issue of "where and for whom" the goods are to be sold.

- Technological and functional execution, that is, the ways to satisfy the needs of a consumer.

Gaining an increased level of competitiveness strategy of an enterprise is the mission, that is, key instruction, which indicates the direction of focus of separate tasks, which direct intentions of managers towards certain strategic goals and actions needed to achieve them. This higher level must certainly be general and be developed for long-term.

The next level of competitiveness strategy of enterprise describes the strategic direction in more details. A more detailed description is provided by functional strategies (from research and development to production, distribution, sales, prices and etc.) as well as by programs of development of new products and projects of basic investment, such as the construction of new plants and modernization of existing ones. At this level, basic attention is paid to specific types of activities related to the expenditure of time, funds and energy, which significantly affects the strategic directions of the business. This may occur only when strategy elements strengthen and do not contradict each other. So in a wider sense, the competitiveness strategy should be focused on the unification of strategic efforts of different functional subdivisions of enterprise (purchase, production, research and development activities, finances, personnel divisions, sales, marketing, etc.) [34 p. 44].

There is high competition for investment worldwide, and an increase of Ukraine's rating position and domestic business structures is the indicator of attractiveness international corporations look for. Doing Business is one of the key ratings, which is considered by investors when they plan to locate their production in this or any other country.

Modern states' economies built on market principals, try to develop and implement state regulation to reduce negative consequences of inabilities of the market. According to the inability theory, states are divided into groups of states, which are symmetric to features of the market and group of states, which require the similar set of instruments for their reduction. That is, the occurrence of any crisis directly indicates the intensifying of certain inabilities of the market or the state. That is why identification and overcoming of inabilities is the prime task on the list within the frame of the reformation of economic system [35 p.11].

The position of the state in international ratings is the informative index of the efficiency of state policy in different spheres, particularly, economic, which is taken into account by the leading international creditors and companies in the implementation of credit and investment.

- Global competitiveness index. Within the frame of the global competitiveness ranking, the Competitiveness index determines the ability of an economy to grow in the long-term period. It consists of 114 indicators, 2/3 of which are the results of a survey of business leaders, 1/3 - statistical information.

- Ease of Doing Business index. The index is calculated on the basis of ten indicators (which constitute methodology of Doing Business Project): the creation of business, work with construction permits, connection to electricity, registration of property, obtainment of credit, protection of investors, payment of taxes, trade across borders, enforcement of contracts, closure of businesses.

- Global innovation index. The \index covers 7 key elements of research: institutions; human capital and research; infrastructure; market experience; entrepreneurial experience; knowledge and technology (scientific and practical results) and results of creative activities.

- Economic freedom index. The experts of the American research center The Heritage Foundation define economic freedom as "the absence of government intervention or obstruction of the production, distribution and supply of goods and services, except for the necessary protection and support of freedom for citizens as such." The degree of freedom of the economy is calculated on the basis of the arithmetic average of ten indicators: freedom of business, trade, financial sector, investment, labor, monetary and fiscal freedoms, guarantees of property rights, the volume of the bureaucracy and the degree of protection against corruption. Thus, the result of "absolutely free" economy should be 100 points, and where there is no freedom in general, respectively, zero. 
- The Investment attractiveness index. The evaluation of investment attractiveness is performed by the European Business Association and is based on regular monitoring of the business climate by the first persons of companies, which are Association members.

The strategy of the decentralized regulation is characterized by more indirect state participation in the investment development of separate organizations and business entities. This means a lower centralization degree of management of investment processes by the state. The state implements its investment policy by creating innovations in the public sector. The state allocates appropriate resources in order to create an initial demand for innovations. The tax incentives and other preferences for investment activities are provided to implement this strategy.

The strategy of the decentralized regulation provides for the transfer of the initiative to business entities. The state uses tax and other incentives for investment development and creates favorable legal, investment, technical and economic conditions for this activity. This strategy is the most widespread in the US, UK and other countries.

Technological development of any state is impossible without effective functioning of mechanisms of technology transfer as an element of the national innovation system.

Technology transfer plays a decisive role in spreading objects of intellectual property rights. In a broad sense, the latter means interaction between two or more partners, in cases when at least one of them transfers their technology through know-how, patents and technical assistance to the other partner, who wishes to implement and use this technology for a specific purpose [36, p. 30]. This definition does not consider technology transfer as a commercial phenomenon, as it can serve to increase the amount of knowledge/knowhow of one party without any financial transaction. However, the basic rule of technology transfer is that both parties should receive profit from it on a mutually beneficial basis. A technology recipient, for example, can acquire know-how and gain a technological advantage over competitors, and a technology owner can gain some financial benefit from cooperation and develop other technological solutions to improve competitiveness, reduce costs and increase profits.

Ukrainian Institute of science, technical and economic information (UkrINTEL) carries out activities in the field of technology transfer in Ukraine. UkrINTEL activities in the sphere of technology transfer are aimed at the implementation of the operational provision of necessary scientific and technical information and relevant technical solutions to developers, manufacturers, consumers of high technologies and potential investors, as well as at promotion of the development of partnership relations between Ukraine and the international community.

The concept and methodology of the National technology transfer network are developed in accordance with the methodology and the model of the European network of "relay centers" (Innovation Relay Centers - IRC network, since 2008 - EEN), the Russian technology transfer network RTTN and Ukrainian technology transfer network UTTN.

The overall management of the work is carried out by the National Aeronautics and Space Administration (NASA). The established network has the nature of a general federation and assists all other interested agencies in matters of technology transfer. All of this contributes to the activation of development and transfer of technology at all levels. The government does not provide direct financial support for the activities of technology transfer centers (CCS), however, it gives the universities, non-profit organizations and small business firms the right to transfer the license to commercial use of inventions made in the course of the research with the financial support of the government and industrial companies.

The function of technological intermediaries between laboratories and companies in Germany is performed by different scientific companies and joint research associations in the industry. Fraunhofer Society has the leading organizational role. After the unification of Germany, it united 45 research universities, including 9 from the former GDR. Their activities are financed through subsidies from the federal government and the incomes from the execution of contract research. The transfer of the technologies created with the use of the budget funds was carried out on the following strategic priorities of innovation activity: 
1. Development of new technologies of energy transportation, introduction of energy-efficient, resource-saving technologies, development of alternative energy sources.

2. Development of new technologies of high-tech development of the transport system, rocket and space industry, aircraft and shipbuilding, weapons and military equipment.

3. Introduction of new technologies and equipment for qualitative medical care, treatment, pharmaceuticals.

4. Wide application of cleaner production and environmental protection technologies.

It should be taken into account that innovation activity is a venture business. This means that previously no one in our state was engaged in this activity and that the motivation to engage in innovation activities is to obtain high profits.

\section{Conclusions}

The study of theoretical and methodological bases of investment activities, which was made within the frame of the article, gave the opportunity to formulate relevant conclusions that have theoretical and practical significance. The theoretical foundations of investment activity in Ukraine were generalized and systematized. It is determined that the methodology of investment activity study, which is used to determine, compare and justify alternative management decisions, is accompanied by the implementation of project analysis, which is a multi-stage, complex and diligent process and includes: technical, organizational, institutional, management, environmental, commercial, financial and social analyzes, they are recommended to be considered in a progressive iterative order. It is proved that the main elements of the project analysis are formed according to local indicators, which reflect the main objectives of investment activities.

It is determined that, in general, the policy of foreign states concerning the investment sphere pursues the following main objectives: the direction of investment on the restructuring of the economy to improve its efficiency; the circulation of savings in the investment of the real sector of the economy; the formation of an effective and controlled capital market; reduction and insurance of investment risks; the improvement of the investment climate for domestic and foreign capital, etc.

It is proved that the public nature of the investment process itself requires structuring the investment resources and coherence of the state's influence on the investment process. The opinion that the mortgage financing system is an effective means for accumulation and redistribution of money, transformation of private savings into the investment resources, creation of instruments for stimulation of development of domestic financial market as well as increase in efficiency of the state economic policy, in general, was substantiated. At the same time, the complexity of market mechanisms of mortgage market functioning, constant transformation of financing processes and ineffective use of legally determined mechanisms of investment and financing determine the relevance for improvement of the mortgage market organizational level, improvement of forms, methods and instruments for its functioning. Thus, the development of the mortgage market in Ukraine is one of the most important problems at the present stage requiring the urgent solution.

\section{References:}

[1] Postanova Verkhovnoi Rady Ukrainy Pro Rekomendatsii parlamentskykh slukhan na temu: "Stratehiia innovatsiinoho rozvytku Ukrainy na 2010-2020 roky v umovakh hlobalizatsiinykh vyklykiv" vid 21 zhovtnia 2010 r. № 2632-VI [Resolution of the Verkhovna Rada of Ukraine On the Recommendations of the Parliamentary Hearings on the theme: "The Strategy of Ukraine's Innovation Development for 2010-2020 in the context of Globalization Challenges": dated October 21 2010, № 2632-VI]. zakon.rada.gov.ua. Retrieved from http://zakon0.rada.gov.ua/laws/show/2632-17 [in Ukrainian].

[2] T. Ye. Kalashnyk, I. F. Lisna, Problemy innovatsiino-investytsiinoho rozvytku Ukrainy $v$ suchasnykh umovakh [Problems of innovation and investment development of Ukraine in modern conditions]. Biznes Inform - Business Inform, 1 (2014) 60-64 [in Ukrainian].

[3] N. V. Tkalenko, Struktura naukovo-tekhnichnoho potentsialu Ukrainy [The Structure of the ScientificTechnical Potential of Ukraine]. Visnyk ZhDTU. Seriia: Ekonomichni nauky - Bulletin of the ZDTU. Series: Economic Sciences, 56 (2011) 137-140 [in Ukrainian]. 
[4] O.I. Vynokurova, Stratehiia rozvytku derzhavnoi innovatsiinoi diialnosti v Ukraini [The Strategy of Development of State Innovation Activity in Ukraine]. Teoriia ta praktyka derzhavnoho upravlinnia - Theory and Practice of Public Administration, 2 (2010) 1-4 [in Ukrainian].

[5] Zakon Ukrainy "Pro investytsiinu diialnist": vid 18 veresnia $1991 \mathrm{r}$. № 561-XII [Law of Ukraine "On Investment Activity" from September 18, 1991, № 1561-XII]. zakon.rada.gov.ua. Retrieved from http://zakon2.rada.gov.ua/laws/show/1560-12 [in Ukrainian].

[6] Zakon Ukrainy "Pro innovatsiinu diialnist" : vid 04 lypnia 2002, № 36 [The Law of Ukraine "On Innovation Activity" from July 04, 2002, № 36]. zakon.rada.gov.ua. Retrieved from http://zakon5.rada.gov.ua/laws/show/40-15 [in Ukrainian].

[7] Zakon Ukrainy "Pro priorytetni napriamy innovatsiinoi diialnosti v Ukraini": vid 08 veresnia 2011, № 3715-VI [Law of Ukraine "On Priority Areas of Innovation Activity in Ukraine" from September 08, 2011, № 3715-VI]. Vidomosti Verkhovnoi Rady Ukrayiny - Bulletin of Verkhovna Rada of Ukraine, 19-20 (2012) http://zakon3.rada.gov.ua/laws/show/43715-17 [in Ukrainian].

[8] V. H. Prushkivskyi, T. H. Syvolap, Problemy investytsiinoi polityky ta innovatsii natsionalnoi ekonomiky (ekonomiko-ekolohichnyi 154 aspekt) [Problems of the investment policy and innovations of the national economy (economic-ecological aspect 154)]. Ekonomichnyi prostir - Economic space, 47 (2011) 115-123 [in Ukrainian].

[9] Sait InvestUkraine [Site of InvestUkraine]. www.investukraine.org. Retrieved from http://www.investukraine.org [in Ukrainian].

[10] M. V. Haman, Derzhavne upravlinnia innovatsiiamy: Ukrayina ta zarubizhnyi dosvid [State Innovation Management: Ukraine and foreign experience], Viktoriia, Kyiv, 2004 [in Ukrainian].

[11] B. E. Holovash, Dosvid Yevropeiskoho Soiuzu u formu- vanni investytsiino-innovatsiinoi polityky [The Experience of the European Union in the Formation of Investment-Innovation Policy]. Formuvannia rynkovykh vidnosyn v Ukraini - Formation of Market Relations in Ukraine, 11 (2011) 62-66 [in Ukrainian].

[12] V. H. Andriichuk, M. T. Fleichuk, A. T. Mokii, (Eds.). Investytsiina bezpeka perekhidnykh ekonomik v umovakh hlobalnoi intehratsii: teoretyko-metodolohichni pidstavy ta prykladni aspekty [Investment security of transition economies in the conditions of global integration: theoretical and methodological grounds and applied aspects]. Donetsk, 2012 [in Ukrainian].

[13] Industry 4.0 - na porozi nastupnoi promyslovoi revoliutsii [Industry 4.0 - on the eve of the next industrial revolt]. (May 06, 2014). appau.org.ua. Retrieved from https://appau.org.ua/publications/industry-4-0-naporozi-nastupnoyi-promyslovoyi-revolyutsiyi-2/ [in Ukrainian].

[14] The 2013 Global Innovation 1000 Study: navigating the digital future (2014). www.strategyand.pwc.com. Retrieved from https://www.strategyand.pwc.com/media/file/Strategyand_2013Global-Innovation-1000-Study-Navigating-the-Digital-Future_Media-Report.pdf [in English].

[15] Osnovni pokaznyky zovnishnoi torhivli Ukrainy [Main indicators of foreign trade of Ukraine]. (n.d.). ucab.ua. Retrieved from http://ucab.ua/ua/doing_agribusiness/zovnishni_rinki/osnovni_pokazniki_zovnishnoi_torgivli_ukraini [in Ukrainian].

[16] V. M. Heits et al. (Eds.). Innovatsiina Ukraina - 2020: natsionalna dopovid [Innovative Ukraine 2020: National Report]. Kyiv, 2015 [in Ukrainian].

[17] L. M. Meshkun, Nimetska ta shvedska modeli pobudovy sotsialno-oriientovanoi rynkovoi ekonomiky [German and Swedish models for building a socially oriented market economy]. Naukovyi visnyk ChDIEU. Seriia 1: Ekonomika - Scientific Bulletin of the CSTU. Series 1: Economics, 3 (2014) 31-37 [in Ukrainian]. 
[18] Archív Kechnecké Noviny (2008-2013). www.kechnec.sk. Retrieved from http://www.kechnec.sk/clanok/archiv-kechnecne-noviny [in Slovakian].

[19] N. T. Rud, Yu. M. Havryliuk, Intelektualnyi potentsial: faktory formuvannia i realizatsii [Intelligent Potential: Formation and Implementation Factors]. Ekonomichni nauky. Ser.: Ekonomika ta menedzhment - Economic sciences. Sir: Economics and Management, 8 (2011) 283-297 [in Ukrainian].

[20] I. R. Buzko, N. H. Ahafonova, Doslidzhennia chynnykiv, shcho vplyvaiut na formuvannia i rozvytok intelektualnoho potentsialu pidpryiemstva [Investigation of the factors influencing the formation and development of the intellectual potential of the enterprise]. Prometei - Prometheus, 33 (2010) 59-63 [in Ukrainian].

[21] S. Arkhiiereiev, O. Popadynets, (n.d.). Pidvyshchennia roli rehioniv u vypusku vysokotekhnolohichnoi ta innovatsiinoi produktsii: mizhnarodnyi dosvid [Increasing the Role of Regions in the Issue of High-Cognition and Innovative Products: International Experience]. old.niss.gov.ua. Retrieved from http://old.niss.gov.ua/Monitor/november08/5.htm [in Ukrainian].

[22] V.I. Hunko, Pokaznyky, indykatory ta kryterii rozvytku intelektualnoho potentsialu zainiatoho naselennia [Indicators, indicators and criteria for the development of the intellectual potential of the employed population]. Visnyk Sumskoho natsionalnoho ahrarnoho universytetu. Finansy i kredyt - Bulletin of the Sumy National Agrarian University. Finance and Credit, 1 (2013) 190-197 [in Ukrainian].

[23] M. V. Paladii, Efektyvne vykorystannia intelektualnoho potentsialu natsii - neobkhidna umova innovatsiinoho rozvytku ekonomiky derzhavy [Effective use of the intellectual potential of the nation is a prerequisite for the innovative development of the state's economy]. Nauka ta innovatsii - Science and Innovation, 5, 3 (2009) 51-54 [in Ukrainian].

[24] B.I. Pshyk, S. B. Kopytko, Rol intelektualnoho potentsialu u zmitsnenni ekonomichnoi bezpeky derzhavy [The Role of Intellectual Potential in Strengthening Economic Security of the State]. Sotsialnoekonomichni problemy suchasnoho periodu Ukrainy - Socio-economic problems of the modern period of Ukraine, 2 (2016) 24-27 [in Ukrainian].

[25] I. V. Fedulova, Teoretychne obgruntuvannia sutnosti in- novatsiinoho potentsialu [Theoretical Explanation of the Essence of Innovation Potential]. Halytskyi ekonomichnyi visnyk - Galician Economic Journal, 15 (2007) 43-51 [in Ukrainian].

[26] L. I. Fedulova, M. O. Kolosh, Innovatsiinyi potentsial pidpryiemstva yak faktor zabezpechennia rezultatyvnosti restrukturyzatsii [Innovative potential of the enterprise as a factor for ensuring the effectiveness of restructuring]. Naukovi pratsi MAUP -Scientific works of IAPM, 3 (2007) 48-51 [in Ukrainian].

[27] Zakon Ukrainy "Pro naukovu i naukovo-tekhnichnu diialnist" : vid 26 lystopada 2015 r., № 848-VIII [The Law of Ukraine "On Scientific, Scientific and Technical Activity" dated November 26 2015, № 848-VIII]. zakon.rada.gov.ua. Retrieved from http://zakon5.rada.gov.ua/laws/show/848-19 [in Ukrainian].

[28] E. M. Zabarna, Innovatsiino-investytsiinyi faktor ekonomichnoho rozvytku Ukrainy [Innovationinvestment factor of the economic development of Ukraine]. In-t problem rynku ta ekon.-ekol. doslidzhen NAN Ukrainy, Odessa, 2006. [in Ukrainian].

[29] I. V. Yukhnovskyi, Sutnist ta struktura innovatsiino- investytsiinoho potentsialu ekonomiky: osnovni pidkhody ta napriamy formuvannia [The essence and structure of the innovation and investment potential of the economy: the main approaches and directions of formation]. Ukrainskyi sotsium - Ukrainian society, 2 (2010) 159-171 [in Ukrainian].

[30] N. Yu. Tymoshenko, N. V. Menshykh, Problemy rozvytku innovatsiinoi ta investytsiinoi diialnosti v Ukraini [Problems of development of innovation and investment activity in Ukraine]. Investytsii: praktyka ta dosvid - Investments: practice and experience, 12 (2015) 35-38 [in Ukrainian]. 
[31] A. A. Danylenko, Aktualni pytannia priamykh inozemnykh investytsii do Ukrainy z YeS (u konteksti rozshyrennia Yevrosoiuzu na Skhid) [The urgent issues of direct foreign investment in Ukraine with the EU (in the context of the enlargement of the European Union to the East)]. Finansy Ukrainy - Finance of Ukraine, 1 (2008) 127-137 [in Ukrainian].

[32] V. H. Bodrov, O. M. Safronova, N. I. Baldych, Derzhavne rehuliuvannia ekonomiky ta ekonomichna polityka [State regulation of the economy and economic policy]. Akademvydav, Kyiv, 2010 [in Ukrainian].

[33] I. M. Lytsur, Yu. V. Lymych, Chynnyky formuvannia innovatsiino-investytsiinoi polityky staloho rozvytku [Factors of formation of innovation-investment policy of sustainable development]. Efektyvna ekonomika - Effective economy, 9 (2013). Retrieved from http://www.economy.nayka.com.ua/?op=1\&z=2299 [in Ukrainian].

[34] V. M. Zahorulko, M. V. Kolesnyk, Dilova stratehiia pidpryiemstva [Business Strategy of the Enterprise: A Course in Lectures]. Vydavnytstvo Natsionalnoho aviatsiinoho un-tu "NAU-druk", Kyiv, 2008 [in Ukrainian].

[35] Ya. V. Berezhnyi, D. V. Liapin, D. S. Pokryshka, Problemy ta shliakhy formuvannia spryiatlyvoho instytutsiinoho seredovyshcha dlia pidpryiemnytskoi diialnosti v Ukraini [Problems and ways of formation of a favorable institutional environment for entrepreneurial activity in Ukraine]. in: Ya. A. Zhalila. (Eds.). NISD, Kyiv, 2014 [in Ukrainian].

[36] Ukraina u svitovykh reitynhakh: Hlobalnyi innovatsiinyi indeks [Ukraine in World Rankings: Global Innovation Index]. (n.d.). informal.com.ua. Retrieved from http://informal.com.ua/ratings/ukrajina-u-svitovyhrejtynhahhlobalnyj-innovatsijnyj-indeks [in Ukrainian]. 


\title{
Andrii Vorfolomeiev \\ National Technical University of Ukraine „Igor Sikorsky Kyiv Politechnic Institute” \\ 13 Metalistiv Str., 03057, Kyiv, Ukraine, a.vorfolomeiev@kpi.ua \\ IMPLEMENTATION OF RESOURCE EFFICIENT AND CLEANER PRODUCTION OPTIONS AT UKRAINIAN ENTERPRISES
}

\begin{abstract}
Raising resource efficiency is the key task for green transformation of the Ukrainian industry. Resource Efficient and Cleaner Production Centre assists companies in development of options to enhance resource efficiency and environmental performance. However, monitoring shows that companies do not use high potential identified during in-plant assessments. Main barriers at company level are low awareness of the benefits of the resource efficient and cleaner production approach, limited access to financial resources, inadequate human capacities, and absence of incentives from the state.
\end{abstract}

\section{Key words}

resource efficiency, cleaner production, environmental performance, options implementation, financing

\section{Introduction}

Today, greening the economy is a global trend. This means the transition from development through consumption of natural resources and related environmental damage towards increasing resource efficiency, dematerialization of production and consumption, and developing new value chains. One of the bases of a green economy is resource efficiency, which is one of the top priorities for most countries, regardless of the amount of available natural resources. The transformation of the economy towards resource efficiency contributes to increasing the competitiveness of business, attracting new sources of growth and creating jobs.

Alongside deepening the process of the Ukrainian economy integration to the global economy, a large number of Ukrainian companies are faced with meeting the requirements and standards of new markets. Ukrainian enterprises need to modernize their production processes, improve product quality and reduce costs through increased resource efficiency, which is particularly relevant in the context of the applied Deep and Comprehensive Free Trade Agreement between Ukraine and the European Union.

Ukraine is trying not to step aside from world economic transformations. Therefore, at the national level, the 17 Sustainable Development Goals have been adopted and adapted. Ukraine also supported the Declaration on Cooperation on Environment and Climate Change in the Eastern Partnership and the Batumi Initiative on Green Economy. Within technical assistance from the EU and other international partners, Ukraine introduces certain elements of sustainable consumption and production principles into its legislation [1].

At the same time, Ukraine is at a lower position compared to the Eastern Partnership (EaP) countries (Armenia, Azerbaijan, Belarus, Georgia, Moldova and Ukraine) by 'small and medium enterprises (SMEs) in the green economy' index [2], which includes environmental policies targeting SMEs, incentives and instruments. Other indicators also have room for improvement: e.g. in 2014 energy productivity of Ukraine was the lowest for an EaP region and approximately 3 times lower than European regions [3]. This can be explained by Ukraine's inherited resource intensive industry with large companies, which need resources reallocation for increasing production effecinecy [4]. With general instability in the country and rising prices on main resources such as energy or other production materials these companies are not able to maintain their competitiveness and invest in development. According to national statistics, during 1991-2017, the industries' share of the national GDP structure decreased from $46 \%$ to $21 \%$. The problem of limited access to new technologies and modern methods of improving production is a real fact for the majority of Ukrainian enterprises.

New tasks for building a green resource efficient economy in Ukraine, along with pressing issues of ensuring energy security, efficient use of resources, sustainable growth and job creation, will include work with enterprises. This will mean the emergence of new tools for stimulating such efforts as new laws, norms, fees (taxes), funds, support programs (including international ones). It is important for domestic enterprises to be 
prepared for future changes and challenges and to work on their resource efficiency now, thereby investing in their own future.

Resource efficient and cleaner production (RECP) is a component of circular economy [5]. It means following a complex, consecutive preventive environmental strategy in the industrial processes for increasing economic efficiency of an enterprise, decreasing production risks for personnel and decreasing environmental damage [6]. RECP includes permanent activities for identification of innovative solutions aimed at resource (energy, materials, and water) efficiency and their implementation. RECP activities bring overall positive impact on companies' business performance [7].

In Ukraine, RECP is promoted with support of international organisations. In 2007, United Nations Industrial Development Organization (UNIDO) started with the National Cleaner Production Programme in Ukraine. Then, under the framework of "Promoting the Adaptation and Adoption of Resource Efficient and Cleaner Production (RECP) through the Establishment and Operation of a Cleaner Production Centre (CPC) in Ukraine" the Ukrainian RECP Centre was launched in 2013. The Centre became a part of the large network of Cleaner Production Centres created in the framework of the National Cleaner Production Centres programme [8]. In 2014-2017, resource productivity and environmental performance were also promoted within the framework of the RECP Demonstration Component of the EU-funded Programme "Greening Economies in the European Union's Eastern Partnership Countries" (EaP GREEN). The component was focused on the construction materials sector.

\section{Methods}

In 2013-2017, operating under the UNIDO project "Promoting the Adaptation and Adoption of Resource Efficient and Cleaner Production (RECP) through the Establishment and Operation of a Cleaner Production Centre (CPC) in Ukraine", the RECP Centre delivered RECP assessments of 108 companies, which represented different sectors, preferably those of construction materials, machine building, and food [9, 10, 11]. Another 13 Ukrainian companies from the construction materials sector passed through RECP assessments in framework of the RECP demonstration component under EaP GREEN programme (2014-2017) in 2014-2016 [12]. These assessments meant full analysis of resources consumption (energy, materials, water) and generation of unproductive outputs (waste, wastewater, air emissions) using the RECP methodology [6]. In assessment process, the following factors of production [13] were analysed: material, machines, environment, and energy. Companies obtained the report with developed, feasibility-studied options on improving their resource efficiency. These options corresponded to device/unit, line/cell/multi-machine system, and facility level [14]. The companies then implemented these options considering their own priorities, conditions and resources. There was no additional financial support provided for these companies.

The data for this paper was collected in options implementation monitoring. All assessed companies were contacted (chief engineers or directors), and they provided their outputs via phone, email or personal interview to complete the standard form. The actual effect of options implementation was identified using accounting equipment or additional measurements taking into consideration changes in productivity. In some cases, when it was not possible to identify actual savings, it was made an assumption that option generated output equalled to calculated at the stage of development one.

\section{Influence of financing indicators on implementation of the RECP options}

For 2013-2017, 328 options were developed and proposed to the enterprises. Examples of these options were: replacing equipment, heat insulation, adjusting working regimes, changing technological procedures, etc. [9, $10,11]$. The developed options provided means for companies to save $133^{\prime} 500 \mathrm{MWh}$ of energy, 9'000 t of materials, 2'000'000 t of water, 31'000 t of $\mathrm{CO}_{2}$-eq., and USD 9'000'000 annually. However, due to different reasons, companies implemented 86 options or only near $26 \%$ of those proposed. Despite proved importance of organizational and technical aspects [15], according to the various surveys $[3,16]$, one of the main obstacles for options implementation are financial reasons. In addition, the majority of resource efficiency initiatives and management methodologies are concerned primarily with focus on an economic basis [17]. Therefore, here the relations between options implementation and their financial indicators (like payback period, investments etc.) will be considered. 
Distributions of developed and implemented options depending on their payback period time are presented in Figure 1. It is obvious that options with a lower payback period are more interesting for companies. Thirty-one percent of proposed options have a payback period of less than 1 year. This figure demonstrates the high potential for improvement possessed by Ukrainian enterprises. Such options are the simplest and provide significant economy that enables accumulating funds and resources for investing in improvements. In addition, this number of options with a short payback period shows some issues with systematic work of companies' technical specialists.

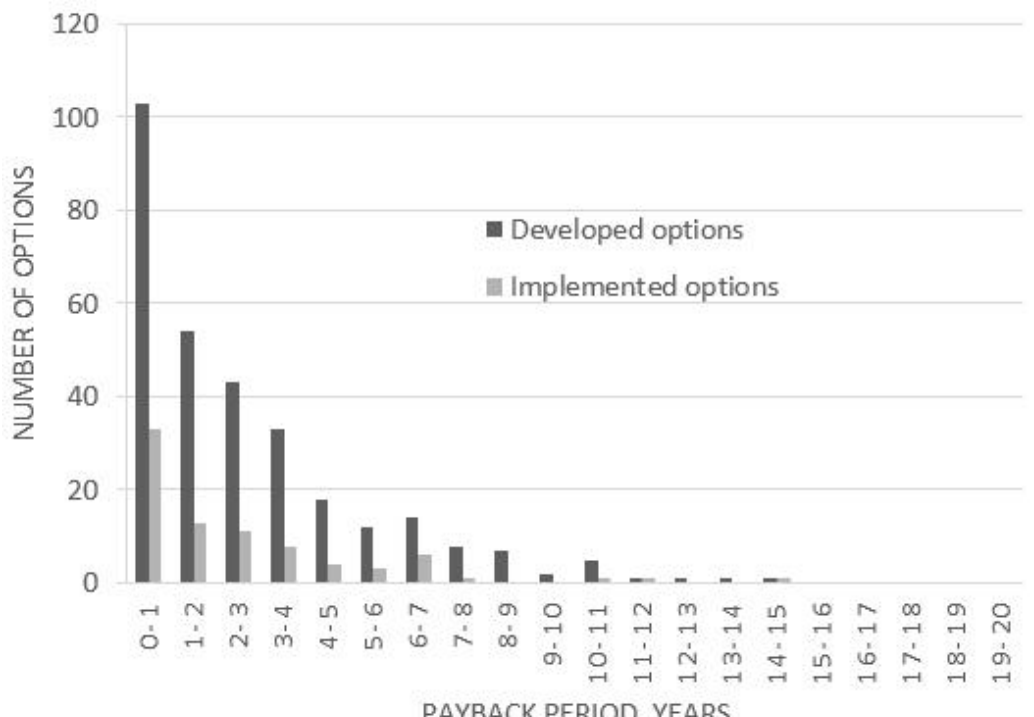

Fig. 1. RECP options and their payback period Source: Author's

Sixty-one percent of proposed options have a payback period of less than 3 years, which also demonstrates the huge hidden potential of Ukrainian enterprises for improving performance and investing. However, the investment attractiveness of Ukrainian companies is low due to general instability in the country.

Only $24 \%$ of proposed options have a payback period of more than 5 years. The reason for this is that Ukrainian entrepreneurs are very sceptical of such options. Knowing this fact, the RECP experts propose such options only in case they have some additional value such as improving company image, meeting work safety issues etc. For example, heat insulation of an administrative building often has a small turnover, however, improves working conditions and looks of the building (and the company image), which is why it may have a high priority for the company.

A large share (40\%) of implemented options are options with a payback period of less than 1 year. For companies' management, these are the easiest decisions - those which do not include any risks. Of the proposed options, 70\% options have a payback period of less than 3 years and $84 \%$ - less than 5 years. Other options are mentioned aside from those with not only economical but also additional (safety, marketing etc.) reasons. This is also explained by the increase of implementation frequency for options with a long payback period (Fig. 2). The RECP experts propose options with a payback period of more than 7 years only in urgent cases and to companies that must implement these options because of multiple reasons.

Figure 2 demonstrates that options with a payback period of less than 1 year have a higher index of implementation (32\%). The share of implemented options is stable for a payback period of from 1 to 5 years (22-25\%). This means that for such companies the payback period does not influence their decision-making process. 


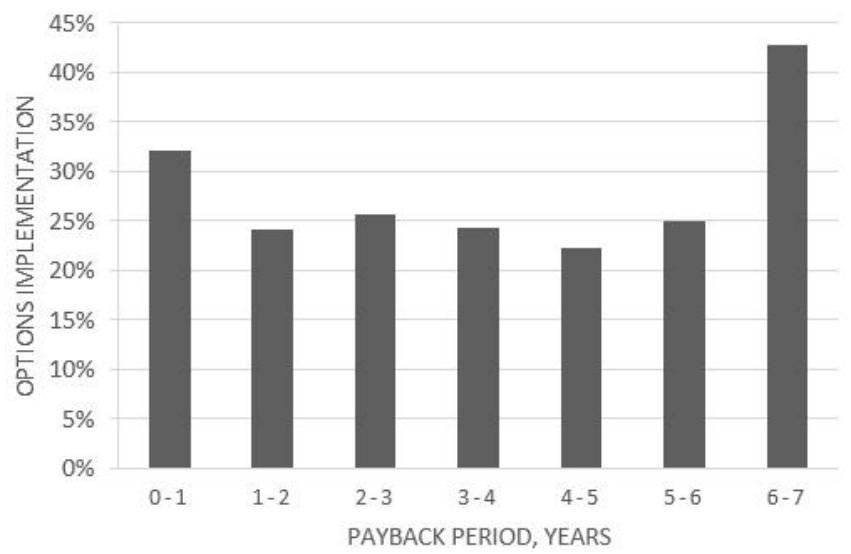

Fig. 2. Implementation of the RECP options depending on their payback period Source: Author's

Distributions of developed and implemented options depending on required investments are presented in Figure 3. Developed options with the lowest investments (below USD 5'000) have the largest share (53\%) in proposed offers. Developed options with investments of less than USD 20 '000 are $77 \%$ of all options. Such options with moderate investments are preferred by consultants and experts. Developed options with investments of more than USD $100^{\prime} 000$ amount to only $7 \%$ of the total number.

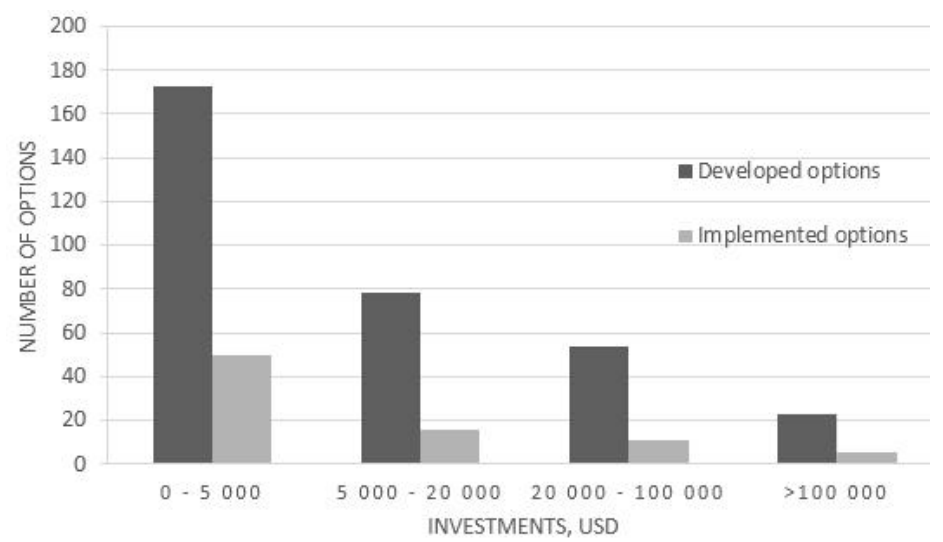

Fig. 3. The RECP options and investments required Source: Author's

The same picture holds true for implemented options. Thus, implemented options with investments less than USD $20^{\prime} 000$ amount to $80 \%$ of all options, while those more than USD $100^{\prime} 000$ are near $6 \%$. Implemented options with investments less than USD 5'000 have a little higher share of $61 \%$ than developed ones. This is also demonstrated in Figure 4. Options with investments less than USD 5'000 have the highest index of implementation $-29 \%$. The reason is their easy implementation and the lower risk. At the same time, indexes implementation for other proposed ranges are quite the same $-20-22 \%$. This could mean that the amount of investment has no influence on making decisions on options implementation; however, it does not correspond to the thesis that financial issues are the main obstacle for options implementation. 


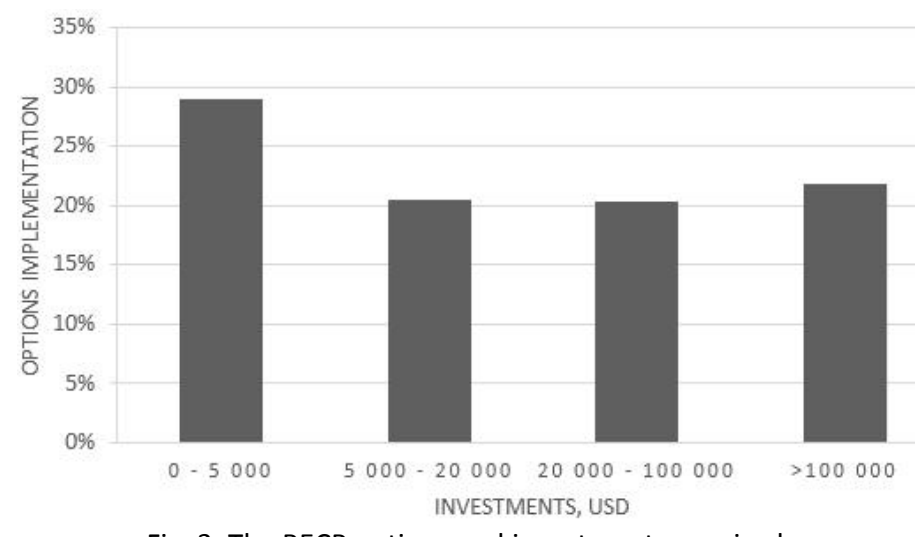

Fig. 3. The RECP options and investments required Source: Author's

\section{Implementing the RECP options at Ukrainian enterprises of construction materials sector}

In Ukraine, the construction materials sector possesses a significant potential for business development; it also can provide a basis for 'green' construction and the sustainable development of urban areas. The potential of its green modernisation was emphasised in the framework of the RECP demonstration component under EaP GREEN programme (2014-2017). In 2014-2016, 13 Ukrainian companies from the construction materials sector passed through RECP assessments which enabled the development of above 100 RECP options with annual

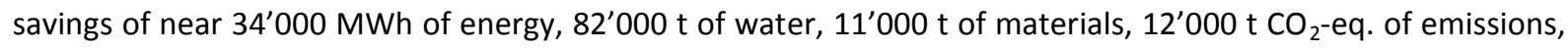
$19^{\prime} 000 \mathrm{t}$ of wastewater, $5^{\prime} 000 \mathrm{t}$ of waste and USD $2.3 \mathrm{mln}$ [12]. However, the identified potential was not fully realized. In 2016-2017, a monitoring of options implementation was carried out. It showed that the companies did implement some options and received some savings: for example, 7'000 MWh of energy, 10'000 t of water, $2^{\prime} 500 \mathrm{t}$ of waste and less than USD $0.5 \mathrm{mln}$, less than one fourth of the potential. The main part of these options were those which were low-cost or without any expenses. In addition, only companies with good economic conditions tried to invest in production modernization.

It is worth mentioning that some companies did not implement developed options due to different reasons. Some of the companies suffered instability because of economic situation in the country. Others lost their markets or could not service their debts. Such companies are now closed or offered for sale. Many companies changed their management and engineering personnel. One of the reasons for this is that there are many qualified specialists are inner displaced people in the Ukrainian labour market. Considering that not all companies were able to implement the options, they were separated between active companies (8 from 13) and inactive (5). General results are very much the same as those mentioned in the previous chapter. For example, cost saving potential was realised at $18 \%$, energy saving $-21 \%$. At the same time, for active companies these indexes are much better $-65 \%$ and $88 \%$ respectively.

Companies paid the most attention to energy saving options, as it is the most expensive resource. Thus, the main part of funds saving is connected with "energy" options. An emissions decrease is connected with energy saving options as well. Materials efficiency was improved by companies, which used expensive materials such as cement and steel armature. Water saving options were not so popular, because for now, water is still a very cheap resource in Ukraine. Good results in waste and wastewater reduction were achieved because companies firstly understood the real cost of these resources and implemented very simple options ("low hanging fruits").

The companies of the first round (2014-2015) achieved better results in the RECP options implementation. For example, this group achieved annual cost savings of USD $440^{\prime} 000$ and energy savings of 6'191'467 kWh. The companies from the second round (2014-2015) achieved annual cost savings of USD 47'000 and energy savings of $816^{\prime} 834 \mathrm{kWh}$. The main reason for the difference was that the companies of the first round had more time to implement these activities and even developed their own options. Aside from not having enough time, the companies of the second round needed management and financial approval and time to synchronize changes with production rhythm. 


\section{Financial barriers for RECP implementation}

A survey conducted by UNIDO in EaP countries showed that small and medium enterprises (SMEs) consider insufficient access to finance to be the greatest obstacle to implementing RECP in their operations, followed by insufficient human resources to ensure adequate compliance with environmental regulations [3].

The survey also shows that Ukrainian enterprises prefer to use their own financial resources without the involvement of external sources. The obtained results coincide with the data of the State Statistics Service of Ukraine: in January-March 2017, enterprises invested near USD $240 \mathrm{mln}$, while the main source of financing was own funds of enterprises and organizations $-68 \%$. Other sources of funding, such as loans, state and local budgets, did not exceed a rate of $5 \%$. Altogether this results in low activity of small and medium-sized businesses in the implementation of resource efficient measures.

The lack of own financial resources can be solved by attracting financing from external sources, such as by lending. Commercial banks and international financial institutions are the main lenders for improving resource and energy efficiency for SMEs. However, in Ukraine the loan rates are the highest compared to other EaP countries. The increasing demands on lending are related with circulating capital issues and debt restructuring rather than investing in resource efficient technologies. Ukrainian enterprises usually try to avoid loans. Thus, among the surveyed companies, only one third of companies considered the possibility of attracting credit funds, and only one third planned to use such funds for the implementation of resource efficient measures [18]. Among the barriers mentioned were the lack of understanding of banks' requirements, lack of qualified staff and, most often, high loan interest rates.

Another opportunity for enterprises to attract funding for implementation of resource efficient options is participation in grant programmes from international organizations and funds. However, such action requires competent personnel with relevant knowledge and experience in writing proposals and drawing international cooperation.

In Ukraine, support and financing for SMEs are mainly implemented through local state business development programmes. All regions of Ukraine have such programmes; however, according to the representatives of enterprises, this mechanism is not attractive due to the small amount of financial resources (USD 7'000-18'000) and the additional attention of the controlling bodies because of the involvement of budget funds. On a national level it is also worth mentioning the launch of Energy Efficiency Fund in December 2017.

Regarding the use of alternative sources of funding, such as crowd funding, engagement of business angels or impact-investors, less than $15 \%$ of Ukrainian SMEs are even familiar with such concepts and principles of cooperation [18].

\section{Summary and conclusions}

Results of more than 100 RECP assessments of Ukrainian enterprises show their great potential for increasing resource efficiency. The high achievability of this potential is demonstrated by the fact that $53 \%$ of developed RECP options for enterprises need investments of less than USD 5'000 and 31\% of proposed options have a payback period of less than 1 year.

Ukrainian enterprises prefer to implement low-cost RECP options and options with a short payback period. Therefore, the largest share (40\%) of implemented options are options with a payback period of less than 1 year and options with investments of less than USD 5'000 (61\%). At the same time, the investments and payback period have high influence on decision-making process only if they are less than USD 5'000 and 1 year respectively. For other investments and payback periods from 1 to 5 years the index of implementation is close (20\%-26\%). Options with a payback period of more than 5 years are considered and implemented only in case of additional motivation. Ukrainian companies are mainly interested in improving efficiency of energy and lessening expensive raw materials consumption.

Financing issues are one of the main obstacle for implementation of resource efficiency options and other innovation activities at Ukrainian enterprises. Ukrainian SMEs try to use only their own funds. Another gap to be filled is building capacity by actions such as personnel trainings as well as providing convenient and available sources of actual information on financing opportunities for SMEs. 
Directions for future investigations may be an analysis of time frames of the RECP options implementation. That will allow finding a period of company support by external experts (consultants) in order to help achieve the successful implementation of the proposed options.

\section{Acknowledgements}

The author wants to explicitly acknowledge the input received from colleagues from Resource Efficient and Cleaner Production Centre (Ukraine), who helped in monitoring data collection.

\section{References}

[1] J. Brizga, Z. Mishchuk, A. Golubovska-Onisimova, Sustainable consumption and production governance in countries in transition, Journal of Cleaner Production, 63 (2014) 45-53.

[2] Policy Index: Eastern Partner Countries. Assessing the Implementation of the Small Business Act for Europe. OECD Publishing, Paris, 2015.

[3] Financing Resource Efficient and Cleaner Production by SMEs in the EU Eastern Partnership Countries: a Stakeholders' Guide, UNIDO and OECD, 2018.

[4] M. Ryzhenkov, Resource misallocation and manufacturing productivity: The case of Ukraine, Journal of Comparative Economics, 44 (2016) 41-55.

[5] M. Geissdoerfer, P. Savaget, N. Bocken, E.J. Hultink , The Circular Economy - a new sustainability paradigm?, Journal of Cleaner Production, 143 (2017) 757-768.

[6] J. Fresner, V. Dobes, T. Bürki, C. Angerbauer, K. Tiefenbrunner, PRE-SME - Promoting Resource Efficiency in Small \& Medium Sized Enterprises, United Nations Environment Programme, 2010.

[7] S.X. Zeng, X.H. Meng, H.T. Yin, C.M. Tam, L. Sun, Impact of cleaner production on business performance, Journal of Cleaner Production, 18 (2010) 975-983.

[8] R. Luken, R. Van Berkel, H. Leuenberger, P. Schwager, A 20-year retrospective of the National Cleaner Production Centres programme, Journal of Cleaner Production, 112, Part 1 (2016) 1165-1174.

[9] Assessment of the Resource Efficiency of Companies: Best Practices - 2014. Informational catalogue, Resource Efficient and Cleaner Production Centre, 2015.

[10] Resource Efficiency Assessment at Company Level, Resource Efficient and Cleaner Production Centre, 2016

[11] Benchmarking tool. Resource Efficiency Improvement: Best Practice, Resource Efficient and Cleaner Production Centre, 2017.

[12] M. Tsybka, A. Vorfolomeiev, Впроваджені на підприємствах України заходи з ресурсоефективного та чистого виробництва: за результатами демонстраційного РЕЧВ-проекту програми EaP GREEN [Implemented at Ukrainian enterprises resource efficient and cleaner production options: results of demonstrational RECP project under EaP GREEN programme], EaP GREEN, 2017.

[13] M. Gram, A Systematic Methodology to Reduce Losses in Production with the Balanced Scorecard Approach, Manufacturing Science and Technology, 1 (2013) 12-22.

[14] J.R. Duflou, J.W. Sutherland, D. Dornfeld, C. Herrmann, J. Jeswiet, S. Kara, M. Hauschild, K. Kellens, Towards energy and resource efficient manufacturing: A processes and systems approach, CIRP Annals Manufacturing Technology, 61 (2012) 587-609.

[15] M. Dörr, S. Wahrena, T. Bauernhansl, Methodology for energy efficiency on process level, Procedia CIRP, 7 (2013) 652-657. 
[16] Оцінка ринку постачальників послуг з енергоефективності - актуальний стан та розвиток ринку [Assessment of the Market for Energy Efficiency Services Providers - Current State and Market Development], Deutschen Gesellschaft für Internationale Zusammenarbeit (GIZ) GmbH, 2018.

[17] O. Gould, A. Simeone, J. Colwill, R. Willey, S. Rahimifard, A Material Flow Modelling Tool for Resource Efficient Production Planning in Multi-Product Manufacturing Systems, Procedia CIRP, 41 (2016) 21-26.

[18] I. Omelchuk, A. Vorfolomeiev, Можливості фінансування ресурсоефективних заходів на малих та середніх підприємствах України, Промышленность в фокусе [Opportunities for financing resource-efficient measures for small and medium enterprises of Ukraine, Industry is in focus], 58 (2017) 29-33. 


\author{
Anna Lewandowska \\ Poznan University of Economics and Business, Faculty of Commodity Science \\ al. Niepodległości 10 61-875 Poznań, Poland, anna.lewandowska@ue.poznan.pl \\ MULTIFUNCTIONALITY OF PRODUCT SYSTEMS \\ - A GENERAL INSIGHT FROM THE CIRCULAR ECONOMY'S PERSPECTIVE
}

\begin{abstract}
One of the key and simultaneously the most difficult issues within the methodology of the environmental life cycle assessment (as well as related life cycle-based techniques) is solving the problem of the multifunctionality of product systems, which includes the questions crucial for the circular economy: reuse, recycling, transforming by-products into valuable (in the market aspect) co-products, prolonging durability. The present paper aims at familiarizing the questions of multifunctionality and presenting the Circular Footprint Formula (CFF), which has been developed within the pilot stage of the European Commission project related to the common methods of measurement and communication the life cycle environmental performance of products and organisations. An example of PET bottles has been presented and two scenarios have been analysed: (1) a scenario with no recycling (a recycling content $=0$ and a recycling rate $=0$ ) and $(2)$ a scenario with recycling (recycling content $=0.24$ and recycling rate $=0.24$ ). Calculations of life cycle emissions of $\mathrm{CO} 2$ have been made by using the CFF formula. An idea of division environmental burdens and credits between supplier and user of the recycled material has been shown and explained as well.
\end{abstract}

\title{
Key words
}

Multifunctionality, product system, life cycle, circular economy, Circular Footprint Formula

\section{Introduction}

Within the environmental life cycle assessment [1] and related analyses [2-4] the product system (as opposed to the product itself) is subjected to assessment. The product system is understood as "the collection of unit processes with elementary and product flows, performing one or more defined functions, and which models the life cycle of a product". Including the function in the definition of the product system reflects its crucial role within the life cycle techniques. The life cycle assessment (LCA) method (and the abovementioned related tools) is used to assess the potential environmental impact in relation to a specific way for realizing a given function/service. The precise definition of a function and a functional unit is the starting point of each study. Moreover, comparing product systems is possible on condition that their functional equivalence is assured. Despite the fact that it is the condition of each comparative analysis, it is particularly significant in the case of the so-called comparative assertions disclosed to the public ("environmental claim regarding the superiority or equivalence of one product versus a competing product that performs the same function") $[1,5]$. In practice it means that answering the seemingly simple questions such as "should an electrical or a traditional toothbrush be used in order to brush teeth?", "what is a more environment-friendly choice - reading a paper book or an ebook?", "should waste be recycled or incinerated with energy recovery?", "should a product be packed into a glass bottle or a multilayer carton?" can be linked with the necessity to solve complex allocation problems. Nowadays, to a large extent due to the technical development, dematerialization and digitalization, the realization of the function itself may often be possible with the use of totally different products/processes (a paper book vs. an e-book; the application of plant protection products vs. the genetic modification of plants; payment transactions realized with the use of traditional methods vs. electronic payment), of different life cycle specificity (a paper book $\rightarrow$ the use of a renewable wood resource, which is capable of absorbing and accumulating carbon dioxide, the many years' duration of use, a passive product; e-book $\rightarrow$ an electronic device, the many years' duration of use, it is difficult to dismantle it and dispose of it, an active product powered by electrical energy). It all results in the differences between functionally equivalent product systems referring not only to construction, technological, cost-related and environmental issues but also to a large extent to the social ones (e.g. linked with health, comfort, time of realizing a service, as well as the demand for jobs and requirements on the job market). 


\section{Allocation situations and allocation problem-solving procedures in the life cycle techniques}

In the life cycle techniques multifunctionality occurs "if a process or facility provides more than one function, i.e. it delivers several goods and/or services ("co-products")" [2]. In a single product system multifunctionality may occur multiple times, have various background and call for different allocation requirements. From a perspective of LCA practitioner multifunctionality can be analyzed in the context of:

- the background - multifunctionality may be intended (designed) or "spontaneous". In the case of the former multifunctionality results from the construction and way of designing a product (a good, a service) as well as the process (a technology). We may assume that the intended multifunctionality is generated at the stage of production (design) and that the users of these products/technological processes benefit from it. In this case, the multifunctionality can be observed during normal and proper use ("in accordance with the manual"). The "spontaneous" multifunctionality is a certain excess of functionality revealed once a given product or a technological line has been manufactured, which goes beyond the original functionality predicted by designers. It stems from specific and individual decisions of users. It may have a positive impact (prolonging the use due to granting a new application) or a negative impact (premature damage of a product and reducing its durability) on a product system's environmental performance.

- the carrier - the following elements may be the carriers of multifunctionality: a (material, nonmaterial) product, a process, and an organization (which is a set of processes). In the case of products multifunctionality refers to a product's ability to perform specific functions (utility, spectrum of applications), its durability (durability, re-using rate), as well as recyclability and a potential for energy recovery. An example of the designed multifunctionality are smartphones, combined refrigeratorfreezers, cosmetics of a varied spectrum of effect (e.g. nutritional values plus a sun protection filter). An example of the process multifunctionality may be processes (individually and a system of them) leading to co-products, e.g. refining of crude oil, incinerating waste with energy recovery, cow husbandry for dairy and meat, sheep husbandry for wool and meat. Hence, the process multifunctionality is a combination of the process and product (material) functionality. It stems not only from the construction and functionality of machinery (a technological line) but the functionality of materials (the anatomical structure of dairy cows and sheep enables the production of meat and milk/wool, the chemical structure of crude oil enables its refinement and obtainment of various final products, the energy stored in the chemical bonds of waste enables the recovery of energy during incineration). Whether a given process amounts to a multifunctional system or not depends on the combination of the two factors and is inextricably connected with specific conditions in a given place at a given time. If the analysis concerns a sheep farm, which is focused on meat production only, it describes a monofunctional system. What is more, even if sheep were actually sheared and the wool were obtained, but treated as waste (a negative or zero economic value), such a system still does not undergo the allocation procedure. However, if within the same farm the machinery for obtaining wool is installed and wool becomes an intended effect of the activity (relevant entities emerge on the market and shape the demand and price, wool reaches a positive economic value with impact on the farm's solvency), then the wool output flow becomes the functional flow and the farm should be considered two-function and be subjected to allocation. This issue is fundamental from the circular economy's perspective, in which the development of technologies for recovering resources from waste/by-products and transforming them into functional flows is prioritized. It means that installing new technological lines, which transform waste and by-products into valuable products, which are desirable on the market, may lead to changing monofunctional product systems into multifunctional ones. It can also result in spreading allocation in the life cycle studies.

- the place of exposure - from a LCA practitioner's perspective multifunctionality may occur in various parts of a product system (upstream processes, core processes, downstream processes) and relate to different places (life cycle stages, unit processes, activity data, elementary flows).

- operability - multifunctionality may relate to the elements of a product system, which are directly run by the practitioner/commissioner of life cycle assessment with the access to specific data (the foreground system). In such a case the practitioner, who gathers inventory data is obliged to identify the potential sources of multifunctionality problems and methods for solving them. However, the allocation situation also occurs in the parts of the system, which are beyond the direct control of the practitioner or/and commissioner. They can indirectly affect the allocation problem solving in the background system. It is possible due to the intense development of databases and data sets modeled according to different allocation solutions (for instance from the third version of the ecoinvent database the data sets are available in three allocation variation: (1) allocation at the point of 
substitution, (2) allocation, cut-off, by classification, (3) substitution, consequential, long-term) [6]. Such a choice depends on the goal and scope of research (e.g. attributive vs. consequential) and has impact on the remaining elements of the system.

The functional unit is the pillar and the reference point for analyses realized with the use of the life cycle techniques. It is defined as "quantified performance of a product system for use as a reference unit" [1-4]. Not only does it refer to the product system, the process but also it is related to the organization (in the case of the latter it is usually called a reporting unit) $[2,4,7]$. The phenomenon of multifunctionality and the questions of allocation in the life cycle techniques is an artificial creation, an artifact [8] and stems from the application of a functional unit as well as the principle of maintaining the functional equality between the compared product systems. In practice it entails the necessity to isolate certain functions of the system or artificially broaden the system boundaries in order to assure this equality. Multifunctionality stems from the product system's ability to generate parallel functional flows. The allocation dilemma consists in answering the question linked with the method for dividing environmental aspects and the relevant potential environmental impact between functional flows. Allocation is understood as "partitioning the input or output flows of a process or a product system between the product system under study and one or more other product systems" [1, 9]. From allocation's perspective the key element is differentiating between various input/output categories depending on the pertinence of their production/delivery as well as their economic value and contribution to generating income/costs. Thus, the status change from non-functional and functional flows is dynamic and relates to the specificity of the process as well as the technical development and the technological progress. It also results from market mechanisms, the relationship between demand and supply, and the price.

We may distinguish:

- co-products - in compliance with ISO 14040:2006 co-products are defined as "any of two or more products coming from the same unit process or product system" (\# 3.10). These products decide about starting the activity, as obtaining (manufacturing) them is the main objective of the economic activity. Their economic value is high enough to have the key impact on the financial results of the activity. An enterprise's infrastructure is created in order to contribute to obtaining co-products. Coproducts often result from joint production. Joint products are defined as "two or more outputs generated simultaneously, by a single manufacturing process using common input, and being substantially equal in value. Joint products (such as butter, cheese, and cream from milk, and fuel oil, gasoline, and kerosene from crude oil) are separately unidentifiable, and incur undifferentiated joint costs, until they reach the split-off point" [10]. The following goods amount to examples of coproducts: products obtained in the process of crude oil processing (diesel, gasoline, jet fuel, HFO, petroleum coke, refinery hydrogen) [11], electrical energy and heat produced in the heat and power plants [12]. In the context of consequential analyses co-products are determining products ("product output of an activity for which a change in demand will affect the production volume of the activity. Also sometimes called a reference product") [13]. Co-products undergo the allocation procedure [14].

- by-products (dependent products) - products, which do not belong to the group of determining products [13], of less economic importance. The size of production and demand for main products directly determines the demand for by-products. By-products may be reused in the same process and be included in the scope of the Bill of Materials, but are also sometimes used in manufacturing other products (they are embraced by the scope of other product systems). A relevant example is fish processing, within which a cod fillet is the determining product (the main product) and fish mince and codparts (the fish racks including bone, skin, head and offal) are dependent products using as a valuable source of proteins [15]. Another example may be growing and processing corn, in which seeds (the main product) and corn straw (the dependent product) are obtained [16]. The corn straw can be sold for a small price as a valuable fertilizer. By-products can often have little economic value. For this reason, if they are recognized as functional flows, they should be taken into consideration in allocation procedure $[8,17]$.

- $\quad$ waste - waste is no functional flow. It does not have economic value (the price $=0$ ) or generates costs. It does not undergo the allocation procedure [8].

Figure 1 presents some examples of multifunctionality in life cycle analyses. It occurs in the following situations:

- multifunctionality of products (fig. 1 a),

- multifunctionality of output processes (multi-output) (fig. 1 b),

- multifunctionality of input processes (multi-input) (fig. $1 \mathrm{c}$ ), 
- multifunctionality of input and output processes (input-output), including energy recovery (fig. $1 \mathrm{~d}$ ), reuse and recycling (with the closed loop fig. 1 e and the open loop fig. $1 \mathrm{f}$ ).

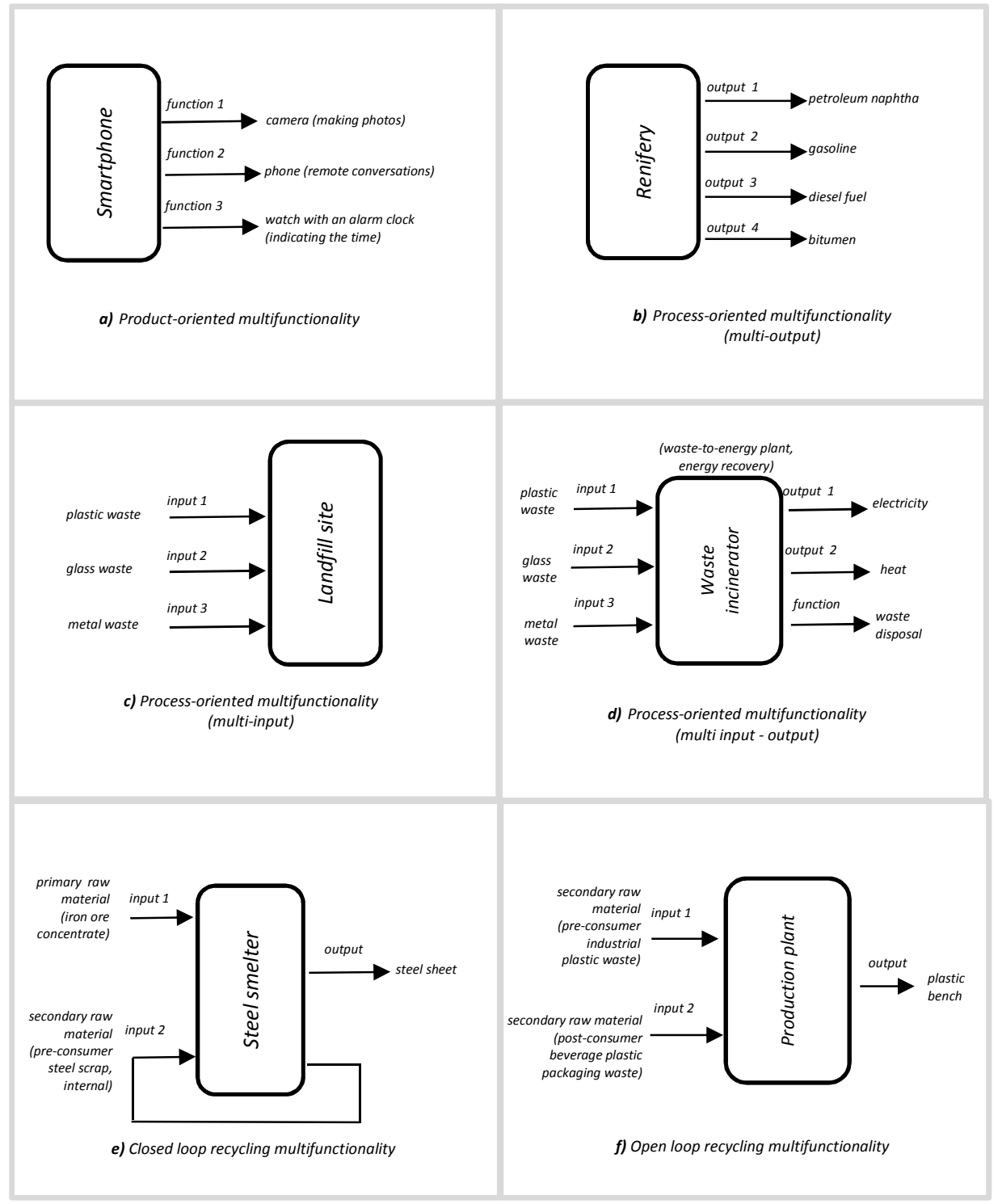

Fig. 1. Examples of multifunctionality in life cycle analyses Source: Author's

In the life cycle techniques (LCA, carbon footprint, water footprint, environmental footprint of products and organisations) the same general procedure is applied to solve allocation problems. However, specific solutions in given situations may be different for specific tools. The general procedure for dealing with the multifunctionality of product systems is hierarchical and has the following form $[3,4,18]$.

"The study shall identify the processes shared with other product systems and deal with them according to the stepwise procedure presented below.

a) Step 1: Wherever possible, allocation should be avoided by

1) dividing the unit process to be allocated into two or more sub-processes and collecting the input and output data related to these sub-processes, or

2) expanding the product system to include the additional functions related to the co-products (...).

b) Step 2: Where allocation cannot be avoided, the inputs and outputs of the system should be partitioned between its different products or functions in a way that reflects the underlying physical relationships between them; i.e. they should reflect the way in which the inputs and outputs are changed by quantitative changes in the products or functions delivered by the system. 
c) Step 3: Where physical relationship alone cannot be established or used as the basis for allocation, the inputs should be allocated between the products and functions in a way that reflects other relationships between them. For example, input and output data might be allocated between co-products in proportion to the economic value of the products".

\section{Circular Footprint Formula as a solution recommended to use for product systems' multifunctionality in the} Environmental Footprint calculations

Within the developmental works of the European Commission on establishing the common methods of measurement and communication the environmental performance in the life cycles of products and organisations [2] an approach to solve multifunctionality problems has been proposed. In the course of the several years' pilot phase the approach evolved and has finally taken the form of the equation called the Circular Footprint Formula (CFF) and presented in Fig. 2 . The CFF has been published in the latest version of PEFCR/OEFSR guidance documents $[19,20]$ and the detailed rules for specific product or sector categories (PEFCRs, OEFSRs). The CFF mainly solves the multifunctionality problem related to recycling and energy recovery.

\section{CIRCULAR FOOTPRINT FORMULA (CFF)}

\section{Material}

$$
\left(1-R_{1}\right) E_{v}+R_{1} \times\left(A E_{\text {recycled }}+(1-A) E_{v} \times \frac{Q_{\operatorname{Sin}}}{Q_{p}}\right)+(1-A) R_{2} \times\left(E_{\text {recyclingEoL }}-E_{v}^{*} \times \frac{Q_{\operatorname{Sin}}}{Q_{p}}\right)
$$$$
\text { Energy }(1-B) R_{3} \times\left(E_{E R}-L H V \times X_{E R, \text { heat }} \times E_{S E, \text { heat }}-L H V \times X_{E R, \text { elec }} \times E_{S E, \text { elec }}\right)
$$

$$
\text { Disposal }\left(1-R_{2}-R_{3}\right) \times E_{D}
$$

\section{Where:}

A: allocation factor of burdens and credits between supplier and user of recycled materials.

B: allocation factor of energy recovery processes: it applies both to burdens and credits.

Q $\sin$ : quality of the ingoing secondary material, i.e. the quality of the recycled material at the point of substitution.

Qsout: quality of the outgoing secondary material, i.e. the quality of the recyclable material at the point of substitution.

$Q_{0}$ : quality of the primary material, i.e. quality of the virgin material.

$R_{1}$ it is the proportion of material in the input to the production that has been recycled from a previous system.

$R_{2}$ : it is the proportion of the material in the product that will be recycled (or reused) in a subsequent system. R2 shall therefore take into account the inefficiencies in the collection and recycling (or reuse) processes. R2 shall be measured at the output of the recycling plant.

Rs: it is the proportion of the material in the product that is used for energy recovery at EoL.

Ereycled (Erec): specific emissions and resources consumed (per functional unit) arising from the recycling process of the recycled (reused) material, including collection, sorting and transportation process.

Erecycing_Ea (Erectol): specific emissions and resources consumed (per functional unit) arising from the recycling process at EoL, including collection, sorting and transportation process.

Ev: specific emissions and resources consumed (per functional unit) arising from the acquisition and pre-processing of virgin material.

E*v: specific emissions and resources consumed (per functional unit) arising from the acquisition and pre-processing of virgin material assumed to be substituted by recyclable materials.

EER: specific emissions and resources consumed (per functional unit) arising from the energy recovery process (e.g. incineration with energy recovery).

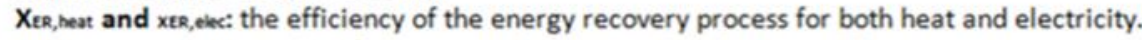

LHV: Lower Heating Value of the material in the product that is used for energy recovery.

Ese,heat and Esteete: specific emissions and resources consumed (per functional unit) that would have arisen from the specific substituted energy source.

Eo: specific emissions and resources consumed (per functional unit) arising from disposal of waste material at the EoL of the analysed product, without energy recovery.

Fig. 2 The Circular Footprint Formula Source: $[18,19]$

The characteristic features of the CFF include:

- including the multifunctionality stemming from recycling (open and closed loop) and energy recovery, 
- the possibility of applying for life cycle of final products (CFF), intermediate products (CFF) and construction products (CFF-M),

- the application of substitution (avoided burdens) through: crediting the recycling process (which introduces the secondary resource onto the market) with the impacts of the avoided production of the substitution primary resource; crediting the energy recovery process with impacts of the avoided production of energy from the market (only for the amount of energy produced in excess and sold),

- the possibility of taking into account of different substitution points,

- including multifunctionality occurring at different life cycle's stages (production, use and final disposal),

- allocating burdens and environmental credits between two life cycles reflecting the situation on the recycling market (the $A$ allocation factor) and the energy market (the $B$ allocation factor).

The idea of applying the CFF is based on the assumption of the substitutability of primary resources in relation to the functionally equivalent secondary resources. If during a specific technological process wasted products (end-of-life) instead of ending up at the landfill become useful materials, then they replace primary resources while entering the market. That is why the processes, which generate the secondary resources that are desirable on the market, are credited (minus sign) with the burdens linked with the production of the equivalent amount of the primary resource. In other words, the erivirurimerita' burdens of t're recycling processes $\left(E_{\text {recycling,EoL }}\right)$ are less the impact of the avoided production of the substitution primary resource $\left(E_{v}^{*}\right)$. This crediting is related to the recycling rate $\left(R_{2}\right)$ and is calculated with the use of the right side of the formula in the "material" column according to the following formula: $(1-A) R_{2} \times\left(E_{\text {recyclingEoL }}-E_{v}^{*} \times \frac{Q_{\text {Sout }}}{Q p}\right)$. On the other hand, the use of the secondary resource in the process in order to mainufacture a product (the $R_{1}$ recycled content) does not cause the avoidance of the use of the primary resource, but leads to the valuable secondary resource's disappearance from the market and its inaccessibility for other applications. In such a situation another producer must use the primary resource in order to fulfill the need to produce other products. Therefore, the process, which uses the seccndary resource $\left(\boldsymbol{E}_{\text {reccled }}\right)$ is burdened (debited, plus sign) with the impact of the production of the primary resource, which must be used up as the result of reducing the demand $\left(E_{\mathrm{v}}\right)$. The debiting is calculated with the use of the left side of the formula in the "material" column according to the formula: $\left(1-R_{1}\right) E_{v}+R_{1} \times\left(E_{\text {recycled }}+(1-A) E_{v} \times \frac{Q_{\text {Sin }}}{Q p}\right)$.

\section{Application of the CFF formula - an example}

Below one may find the presentation of two examples of solving the problem of multifunctionality with the use of the CFF (Fig. 3 and Fig. 4). In the examples the default values of parameters $A, R_{2}, Q_{\text {sin }} / Q_{p}$ and $Q_{\text {sout }} / Q_{p}$ for $P E T$ bottles [20] as well as fictional inventory data linked with the emission rate of specific processes have been used (the examples are given only to illustrate the CFF). The examples have been simplified and limited to carbon dioxide emission (in practice environmental profiles embrace hundreds of environmental interventions). In both case the functional unit (FU) has been defined as "delivering of 40.5 I of water", which means that the reference flow is 27 bottles ( $1 \mathrm{~kg}$ of PET). The first example (Fig. 3) illustrates the life cycle of PET bottles manufactured fully from the primary resource $\left(R_{1}=0\right)$, which are not recyclable $\left(R_{2}=0\right) ;$ thus, $100 \%$ of them are stored at a landfill.

SCENARIO 1 (Functional Unit = delivering of 40.5 I of water Reference flow: 27 bottles $(1 \mathrm{~kg})$

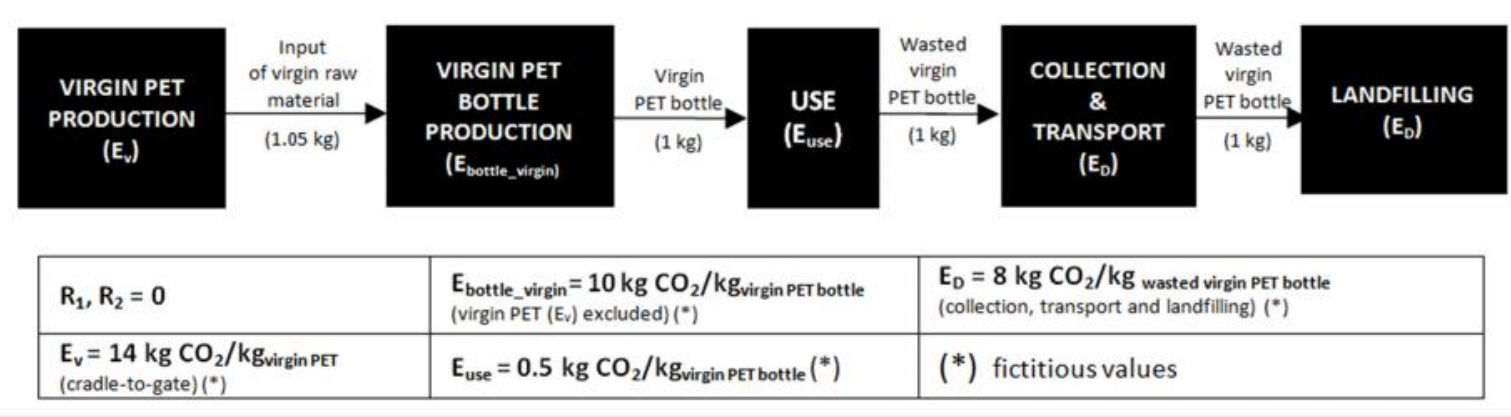

Fig. 3 CFF - scenario 1 - PET bottles with no recycled content $\left(R_{1}=0\right)$ and no recycling rate $\left(R_{2}=0\right)$ Source: Author's 
In the second scenario (Fig. 4) the life cycle of PET bottles, which are manufactured partly from the secondary resource $\left(R_{2}=0.24 \mathrm{~kg} / \mathrm{FU}\right)$ and may be recycled (from $1 \mathrm{~kg}$ of bottles within the output flow of a recycling plant we obtain $0.24 \mathrm{~kg}$ of the marketable secondary resource, $R_{2}=0.24$ ).

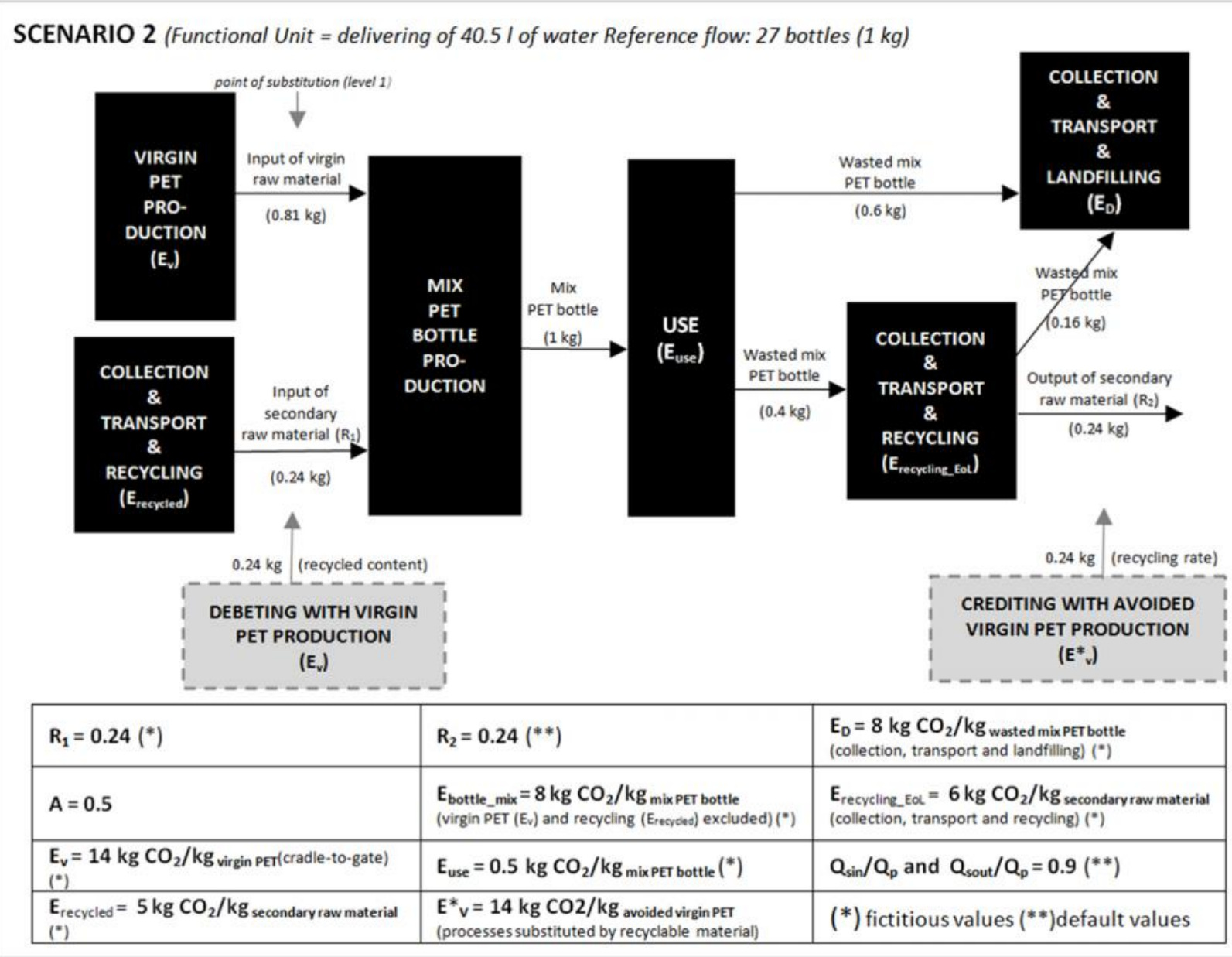

Fig. 4 CFF - scenario $2-$ PET bottles with recycled content $\left(R_{1}=0.24\right)$ and recycling rate $\left(R_{2}=0.24\right)$ Source: Author's

The results of life cycle $\mathrm{CO}_{2}$ emission calculations for both cases have been presented below.

SCENARIO 1 - calculations of $\mathrm{CO}_{2}$ emissions per FU:

- Virgin material input $=1.05 * 14=14.7 \mathrm{~kg} \mathrm{CO} 2$

- Virgin bottle production (without $\mathrm{E}_{\mathrm{v}}$ ) $=1 * 10=10 \mathrm{~kg} \mathrm{CO}_{2}$

- Use of virgin PET bottle $=1 * 0.5=0.5 \mathrm{~kg} \mathrm{CO}_{2}$

- Collection \& transport \& landfilling of wasted virgin PET bottle $=1 * 8=8 \mathrm{~kg} \mathrm{CO}_{2}$ Life cycle $\mathrm{CO}_{2}$ emissions per $\mathrm{FU}$ :

- Life cycle $=14.7+10+0.5+8=\underline{33.2 \mathrm{~kg} \mathrm{CO}_{2}}$ per Functional Unit (1 kg of virgin PET bottles).

SCENARIO 2 - calculations of $\mathrm{CO}_{2}$ emissions per FU:

- Virgin material input $=0.81 * 14=11.34 \mathrm{~kg} \mathrm{CO} 2$

- Secondary material input, as recycled content debited virgin PEF production $=0.24 *((0.5 * 5+(1-0.5) * 14 * 0.9))=2.11 \mathrm{~kg} \mathrm{CO} 2$

- Mix bottle production (without $\mathrm{E}_{\mathrm{v}}$ and $\mathrm{E}_{\text {recycled }}$ ) $=1 * 8=8 \mathrm{~kg} \mathrm{CO}_{2}$

- Use of mix PET bottle $=1 * 0.5=0.5 \mathrm{~kg} \mathrm{CO}_{2}$

- Collection \& transport \& recycling of wasted mix PET bottle, as recycling rate credited with avoided virgin PEF production $=(1-0.5) * 0.24 *(6-14 * 0.9)=-0.792 \mathrm{~kg} \mathrm{CO} 2$

- Collection \& transport \& landfilling of wasted mix PET bottle $=0.76 * 8=6.08 \mathrm{~kg} \mathrm{CO}_{2}$ Life cycle $\mathrm{CO}_{2}$ emissions per FU:

- Life cycle $=11.34+2.11+8+0.5+(-0.792)+6.08=\underline{27.24 \mathrm{~kg} \mathrm{CO}} \underline{2}$ per Functional Unit (1 kg of mix PET bottles). 
The life cycle of $1 \mathrm{~kg}$ of virgin PER bottles (scenario 1 ) hypothetically generates $\mathrm{CO}_{2}$ emission of $33.2 \mathrm{~kg}$. Due to the absence of the secondary resource in production $\left(R_{1}=0\right)$ and the lack of the final product's recycling $\left(R_{2}=0\right)$ the product system has not been either burdened (debited), or credited with emissions generated during the acquisition and pre-processing of virgin material $\left(E_{v}\right.$ and $\left.E_{v}^{*}\right)$. The emission rate of the system of $33.2 \mathrm{~kg}$ stems from the processes of the actual production of the primary resource used fully to manufacture bottles, the bottle production processes, their use and end of life (waste collection, transport and landfilling). In the other case (scenario 2) the abovementioned processes should be complemented with $\mathrm{CO}_{2}$ emission allocated due to multifunctionality. In analyses the default value of parameter $A$ has been used $(A=0.5)$, which means the division of the burdens and credits between supplier and user of the recycled material is equal (50:50). In fact the production process of $0.24 \mathrm{~kg}$ of recyclate as the result of recycling $\left(\mathrm{E}_{\text {recycled }}\right)$ generates the emission of 0.24 $\mathrm{kg} * 5 \mathrm{~kg} \mathrm{CO} 2=1.2 \mathrm{~kg} \mathrm{CO}$. However, the CFF "punishes" the manufacturer for eliminating the secondary raw material from the market (limiting demand) and burdens the result with additional impact according to the following formula: $R_{1} \times\left(E_{\text {recycled }}+(1-A) E_{v} \times \frac{Q_{\text {Sin }}}{Q p}\right)$, which leads to the following calculation: $0.24 *((0.5 * 5$ $+(1-0.5) * 14 * 0.9))=2.11 \mathrm{~kg} \mathrm{CO}$. The difference of $0.91 \mathrm{~kg}$ of $\mathrm{CO}_{2}$ is the environmental consequence of eliminating the secondary raw material from the market and the necessity to use the primary resource by a different producer. Within the end of life the used bottles are recycled. From $1 \mathrm{~kg}$ of bottles we obtain (as an output from a recycling plant) $0.24 \mathrm{~kg}$ of recyclate $\left(R_{2}=0.24\right)$. Therefore, in the second scenario $1 \mathrm{~kg}$ mix of PET bottles has an "inbuilt" potential to generate $0.24 \mathrm{~kg}$ of secondary raw material at the end of its life cycle. The recyclate's entering the market will increase the supply of this resource without further use - and an equivalent amount (after the quality adjustment $0.24 * 0.9=0.216 \mathrm{~kg}$ ) of the primary resource. If we do not apply the CFF we may calculate that the process of acquisition, trarısport arid recycling ( $\mathrm{E}_{\text {recyclingEoL }}$ ) of $0.4 \mathrm{~kg}$ of bottles entails the emission rate of $0.4 * 6 \mathrm{~kg} \mathrm{CO}=2.4 \mathrm{~kg} \mathrm{CO}$. However, the CFF "rewards" PET bottles for their recyclability and gives the environmental credit for their potential of replacing the primary resource. The credit is calculated according to the following formula: $(1-A) R_{2} \times\left(E_{\text {recyclingEoL }}-E_{v}^{*} \times \frac{Q_{\text {Sout }}}{Q p}\right)$, which leads to the following calculation: $(1-0.5) * 0.24 *(6-14 * 0.9)=-0.792 \mathrm{~kg} \mathrm{CO}$. Hence, $2.4 \mathrm{~kg}$ of $\mathrm{CO}_{2}$ emission acquires the credited result at the level of $0.792 \mathrm{~kg} \mathrm{CO}_{2}$. Consequently, the difference of the life cycles' emission rate $\left(33.2-27.24=5.96 \mathrm{~kg} \mathrm{CO}_{2}\right)$ between the two presented examples results from: the recyclability of mix PET bottles (the granted credit), smaller mass of mix PET bottles entering a landfill (scenario $1=1 \mathrm{~kg}$, scenario $2=$ $0.76 \mathrm{~kg}$ ) and the use of secondary raw material in production (the granted debit). Furthermore, the CFF enables taking account of the changes of the secondary resource's quality through downcycling (coefficients of quality adjustment - Q), the situation on the secondary resources market (the A coefficient) and the effects of energy recovery (they have not been taken into account in the presented examples).

\section{Final conclusions}

In the article the phenomenon of the multifunctionality of product systems as well as the general procedure for allocation situations have been discussed. Moreover, examples of the use of the Circular Footprint Formula (CFF) have been provided. The CFF is an approach recommended by the European Commission to apply in the environmental footprint analyses of products and organisations. The multifunctionality of systems is related to the circular economy key phenomena: recycling, energy recovery and reuse. Therefore, one may expect the significant development of recovery technologies (including recycling). It may also be predicted that product systems will produce more valuable and marketable secondary resources. Consequently, it will lead to the situation in which solving the multifunctionality problems of systems becomes common practice in the life cycle analyses.

\section{References:}

[1] ISO 14040 Environmental management - Life cycle assessment - Principles and Framework (2006).

[2] Recommendation 2013/179/EU Commission Recommendation of 9 April 2013 on the use of common methods to measure and communicate the life cycle environmental performance of products and organisations (2013).

[3] ISO 14067 Greenhouse gases - Carbon footprint of products - Requirements and guidelines for quantification (2018).

[4] ISO 14046 Environmental management - Water footprint - Principles, requirements and guidelines (2014) 
[5] M. Finkbeiner, The International Standards as the Constitution of Life Cycle Assessment: The ISO 14040 Series and its Offspring [IN] W. Kloepffer, Background and Future Prospects in Life Cycle Assessment, Springer, Springer Dordrecht Heidelberg New York London, pp.85-106 (2014).

[6] https://www.ecoinvent.org

[7] ISO/TS 14072 Environmental management - Life cycle assessment - Requirements and guidelines for organizational life cycle assessment (2014).

[8] Life Cycle Assessment A product-oriented method for sustainability analysis. UNEP LCA Training Kit Module g - Multifunctionality, allocation \& system boundaries. http://formations.cirad.fr/analyse-cycle-devie/pdf/Heijungs_1.pdf (accessed 20.09.2018).

[9] A. Śliwińska State of the Art on Allocation in LCA and Proposals for Changes in ISO 14044 (Stan wiedzy na temat alokacji w LCA oraz propozycje zmian w normie ISO 14044). Engineering and Protection of Environment (Inżynieria i Ochrona Środowiska). 20/1 (2017) 97-119.

[10] http://www.businessdictionary.com/definition/joint-products.html (accessed 20.09.2018).

[11] C. Morettia, A. Moroa, R. Edwardsa, M.V. Roccob, E. Colombob, Analysis of standard and innovative methods for allocating upstream and refinery GHG emissions to oil products, Appl. Energy. 206 (2017) 372-181. [12] R. Frischknecht, Allocation in Life Cycle Inventory Analysis for Joint Production, Int. J. Life Cycle Assess. 5/2 (2000) $85-95$

[13] https://consequential-lca.org/glossary/ (accessed 22.09.2018).

[14] J. Guinée (Ed.) Handbook on Life Cycle Assessment. Operational Guide to ISO standards. Part 3. Springer. 2002

[15] N.W. Ayer, P. H. Tyedmers, N. L. Pelletier, U. Sonesson, A. Scholz, Co-Product Allocation in Life Cycle Assessments of Seafood Production Systems: Review of Problems and Strategies, Int. J. Life Cycle Assess. 12/7 (2007) $480-487$.

[16] C. E. Canter, J. B. Dunn, J. Han, Z. Wang, M. Wang, Policy Implications of Allocation Methods in the Life Cycle

Analysis of Integrated Corn and Corn Stover Ethanol Production, Bioenerg. Res. 9 (2016) 77-87.

[17] https://www.ecoinvent.org/database/system-models-in-ecoinvent-3/cut-off-system-model/allocation-cutoff-by-classification.html (accessed 22.09.2018).

[18] ISO 14044 Environmental management - Life cycle assessment - Requirements and guidelines (2006).

[19] Product Environmental Footprint Category Rules Guidance Version 6.3 - May 2018 http://ec.europa.eu/environment/eussd/smgp/pdf/PEFCR guidance v6.3.pdf (accessed 22.09.2018).

[20] Organisation Environmental Footprint Sector Rules Guidance Version 6.3 - May 2018 http://ec.europa.eu/environment/eussd/smgp/pdf/OEFSR guidance v6.3.pdf (accessed 22.09.2018).

[21] CFF_Default_Parameters_March2018.xls

http://ec.europa.eu/environment/eussd/smgp/PEFCR_OEFSR_en.htm (accessed 22.09.2018). 


\author{
Aleksandra Czajkowska \\ University of Science and Technology in Bydgoszcz, Faculty of Mechanical Engineering \\ Al. prof. S. Kaliskiego 7, 85-796 Bydgoszcz, e-mail: czajkowska.aleksandra91@gmail.com
}

\title{
THE CHANGES IN THE POLISH ENERGY SECTOR TO REDUCE THE POLLUTANT EMISSIONS IN THE ENVIRONMENT
}

\begin{abstract}
The Polish Energy Sector is one of the most difficult lines of business because among other things, of the existing legal provisions, and standards relating to pollutant emissions. In the coming years, in the Polish Energy Sector breakthrough changes related to develop the energy facilities and with respect to the environmental protection will have to be introduced. During the generation of electricity harmful residues are produced, which are counteracted by equipment designed for flue gas cleaning. The Energy Sector should be concentrating on searching for the implementation of innovations to achieve emission standards.
\end{abstract}

\section{Key words}

environmental protection, EU directives, Decree from the Polish Environment Minister, Duo-block, the reduction of ash particles, $\mathrm{SO}_{\mathrm{x}}$ and $\mathrm{NO}_{\mathrm{x}}$ emissions

\section{Introduction}

European Union Member States must adapt to the changing policy and rules. For many years, activities have been adopted in order to support EU members in the protection of the natural environment, climate and the reduction of greenhouse gas emissions. The activities undertaken enable effective promotion of the use of renewable energy sources in order to obtain electricity [1].

The continuous increase in demand and supply for electricity, in relation to the decreasing access to natural resources, causes a conflict between maintaining energy security and the availability of the sources necessary to generate electricity. The emission restrictions, which are imposed by the European Union on the Polish Energy Sector, promote the generation of electricity from Renewable Energy Sources (e.g. 3×20 climate package) [2].

The natural resource depletion and fast growing technology in cities or industrial plants development will require the satisfying of a higher and higher energy demand. This situation can lead to a situation where the traditional models of energy production in Poland will slowly become insufficient or technologically obsolete as well as the environmental protection. The energy sector should also concentrate on searching for and implementing innovations, to ensure emission standards [3].

\section{EU requirements and Poland's regulations}

The European Commission has developed an energy policy for countries belonging to the European Union, which requires the fulfillment of the aims included in the Green Book [4]. The goals concern the reduction of greenhouse gas emissions by at least $20 \%$ by the year 2020 compared to data from 1990 . In addition, the proportion of energy obtained from renewable sources must also increase to $20 \%$ by 2020 . Furthermore, the new energy policy will be developed by the European Commission and contains:

- an increase in energy efficiency,

- improving energy security,

- $\quad$ extending the area of renewable energy use for biofuels,

- the development of competitive sectors on the energy market (reference to the area of fuels and electricity),

- minimizing the impact of the energy sector on the natural environment.

Topics related to the increase of energy efficiency have been treated in a special way by the European Commission. Completion of this point by EU Member States, will allow achievement of the remaining objectives of the new energy policy, which is being carried out. 
The destructive impact of industrial development on the environmental and climatic changes, offers the opportunity to look at specific assumptions adopted by the European Union in order to counteract these harmful factors. The burning of raw materials and fossil fuels causes the emission of many harmful chemical compounds, which have a negative impact on the natural environment.

A directive of the European Parliament and of the Council 2010/75/EU from 24th November 2010 on the issue of industrial pollution caused the introduction of key changes in Polish law, which concern the environmental protection regulations [5]. The most important changes relate to the introduction of exacerbations in the regulations relating to the emission standards of pollutions by industrial concerns. Primarily, the Industrial Emissions Directive (IED) indicates the reduction of sulfur dioxide, nitrogen oxides and dust produced by energy combustion.

There are also two regulations in the Regulations of the Environment Minister in Poland, which relate to environmental protection and also limiting the emission of dust-gas pollution:

- The Regulation of the Environment Minister of 30th October 2014, concerning the requirements for the measurement of emission volumes and the water amount [6].

- The Regulation of the Environment Minister of 4th November 2014, 4 on the emission standards for certain types of installations, combustion plants and equipment incineration or coincineration of waste [7].

The Regulations in Poland have been specified for limiting the values for emissions of such chemical compounds as $\mathrm{NO}_{x}, \mathrm{SO}_{\mathrm{x}}$ and dust to the environment, depending on the power of the boiler. In the Regulations of the Environment Minister, there are schedules relating to emission standards for devices with a nominal heat output of not less than $50 \mathrm{MW}$. The table below contains a list of selected documents that relate to the requirements affecting the Polish energy sector (Table 1.).

Table 1. A brief summary of documents affecting the Polish energy sector

\begin{tabular}{|c|c|c|}
\hline Type of document & Working area & Objectives included in the document \\
\hline Green Book & $\begin{array}{l}\text { Sustainable, competitive } \\
\text { and safe energy }\end{array}$ & $\begin{array}{l}\text { - increase of energy efficiency } \\
\text { - } \quad \text { improvement of energy security } \\
\text { extension of the RES (Renewable Energy } \\
\text { Sources) use area for biofuels } \\
\text { development of competitive sectors on the } \\
\text { energy market (reference to the area of } \\
\text { fuels and electricity) } \\
\text { minimization of the impact of the energy } \\
\text { sector on the natural environment }\end{array}$ \\
\hline New energy policy & $\begin{array}{l}\text { Energy sector, } \\
\text { renewable energy and } \\
\text { environmental } \\
\text { protection }\end{array}$ & $\begin{array}{l}\text { - increase in the use of renewable energy } \\
\text { sources in the final energy balance } \\
\text { increased importance of biofuels on the } \\
\text { transport fuels market } \\
\text { protection of trees against excessive use for } \\
\text { the production of biomass } \\
\text { rational use of agricultural areas for the } \\
\text { creation of RES areas (Renewable Energy } \\
\text { Sources) }\end{array}$ \\
\hline $3 \times 20 \%$ package & $\begin{array}{l}\text { Power engineering, } \\
\text { including RES } \\
\text { (Renewable Energy } \\
\text { Sources) and reduction } \\
\text { of greenhouse gases }\end{array}$ & $\begin{array}{l}\text { - } \quad \text { reduction of greenhouse gas emissions at } \\
20 \% \\
\text { - } \quad \text { increase of energy efficiency at } 20 \% \\
\text { - use of renewable energy sources in relation } \\
\text { to the total electricity production by } 20 \%\end{array}$ \\
\hline $\begin{array}{l}\text { Directive of the European } \\
\text { Parliament and of the } \\
\text { Council 2010/75 / EU of } \\
\text { November 24, } 2010\end{array}$ & $\begin{array}{l}\text { Emissions of industrial } \\
\text { pollution and regulations } \\
\text { on environmental } \\
\text { protection }\end{array}$ & $\begin{array}{l}\text { - } \text { reduction of sulfur dioxide, nitrogen oxides } \\
\text { and dusts originating from energy } \\
\text { combustion } \\
\text { implementation of the so-called flexible } \\
\text { derogation mechanism }\end{array}$ \\
\hline
\end{tabular}




\begin{tabular}{|c|c|c|}
\hline Type of document & Working area & Objectives included in the document \\
\hline Transitional National Plan & $\begin{array}{l}\text { Industrial facilities } \\
\text { and reduction of } \\
\text { emissions from industry }\end{array}$ & $\begin{array}{l}\text { - introduction of sulfur dioxide, nitrogen } \\
\text { oxide or flue gas emission standards } \\
\text { reduction of emitted harmful chemical } \\
\text { compounds by industrial facilities }\end{array}$ \\
\hline $\begin{array}{l}\text { Regulation (EC) No } \\
\text { 166/2006 of the European } \\
\text { Parliament and of the } \\
\text { Council of } 18 \text { January } 2006\end{array}$ & $\begin{array}{l}\text { Pollutant Release and } \\
\text { Transfer Register (PRTR) }\end{array}$ & $\begin{array}{l}\text { - a register is a tool to enable the public to } \\
\text { access environmental information about } \\
\text { the transfer of pollutants into the air, } \\
\text { water, soil, form different industrial plants }\end{array}$ \\
\hline $\begin{array}{l}\text { Regulation of the Minister } \\
\text { of the Environment of } \\
\text { August 14, 2009 (Journal of } \\
\text { Laws No. 141, item 1154) }\end{array}$ & $\begin{array}{l}\text { Reports on the creation } \\
\text { of the National Pollutant } \\
\text { Release and Transfer } \\
\text { Register }\end{array}$ & $\begin{array}{l}\text { introduction of a report template on the } \\
\text { amount and type of pollution released by } \\
\text { the plant during the year }\end{array}$ \\
\hline
\end{tabular}

Source: Author's

Fulfillment the EU's requirements by the Polish energy industry, which relate to reducing emissions of pollutants, will be a long and extremely expensive process. Expenditure incurred to build a modern, highefficiency block with a high power significantly exceeds the expenditure on the revitalization of an energy facility with the same parameters. Investors decide to choose the second option, firstly for economic reasons, secondly with a view to introducing stricter EU standards in the future (for example, price increases for the emission of carbon dioxide into the atmosphere).

Performing the revitalization of facilities, in the energy sector means modernizing the existing power units, for example, improving turbine and boiler modules, or expanding it with installation to capture sulfur dioxide, nitrogen dioxide, and with the reduction of dust pollination to the environment. The implementation of the above-mentioned measures enables extending the working time of modernized power units, of course after confirming that the relevant emission standards have been met. Performing revitalization allows for extending the operation of power facilities even up to 2030, in the implementation of certain conditions imposed by the European Union. Activities modernizing energy facilities make it possible for the energy sector to meet the requirements of EU directives and obtaining a high level of efficiency of individual elements of the power unit.

\section{Conventional installations of exhaust gas cleaning systems}

The side effect of energy production by a power station is the generation of toxic pollutions in the environment.

In the dust removal during the flue gas cleaning process there can be found such chemical compounds as: oxides $\left(\mathrm{O}_{2}\right)$, in particular carbon monoxide $(\mathrm{CO})$, sulfur dioxide $\left(\mathrm{SO}_{2}\right)$, carbon dioxide $\left(\mathrm{CO}_{2}\right)$, nitrogen dioxide $\left(\mathrm{NO}_{2}\right)$, hydrogen fluoride (HF) and carbon tetrachloride $\left(\mathrm{CCl}_{4}\right)$ [8]. In power units, apart from the installation of the fuel combustion process, are devices for converting the thermal energy generated by an energy boiler, to electricity. These are the following objects [9]:

- turbines;

- turbogenerators;

- cooling system with a condenser (condenser);

- auxiliary devices producing heat energy during boilers' working periods (in the case of using steam turbines).

The above list of devices converting thermal energy into electricity is very general. Each installation included in the power units mainly depends on the character of the production and the fuel used. Most of the chemical compounds listed at the beginning are highly toxic for people and for the environment. In order to capture dust and gas particles in the power unit, installations for flue gas desulphurization, denitrification and removal of dust are used (PM 10 and PM 2.5) [10].

\section{Flue gas desulfurization methods}

There are three methods for flue gas desulphurization. The wet method consists in humidifying the exhaust gases in the chamber by water, which contains a factor that allows the absorption of sulfur dioxide into the liquid. During the desulphurization process, the exhaust gases are cooled to a temperature per $50-60^{\circ} \mathrm{C}$. 
This method consists in washing the flue with an aqueous lime suspension or limestone in the absorption tower, resulting in calcium sulfite $\left(\mathrm{CaSO}_{3}\right)$. Additional oxygenation of $\mathrm{CaSO}_{3}$ causes its conversion to $\mathrm{CaSO}_{4}$, which after precipitation from the solution is treated (washing and dehydration) resulting in gypsum $\left(\mathrm{CaSO}_{4} \mathrm{X}\right.$ $2 \mathrm{H}_{2} \mathrm{O}$ ). The limestone powder or quicklime powder it is pre-prepared in the form of an aqueous suspension in the right installation. It is then pumped to the absorber by means of pumps. A special circulation pump system, pipelines and nozzle system ensures intensive washing exhaust inside the absorption column. The effectiveness of the process depends to a large extent on the intensity of flue gas washing. This method is one of the first and oldest ways to eliminate sulfur compounds from fumes [11]. Wet desulfurization installations are presented in the diagram below (Fig. 1).

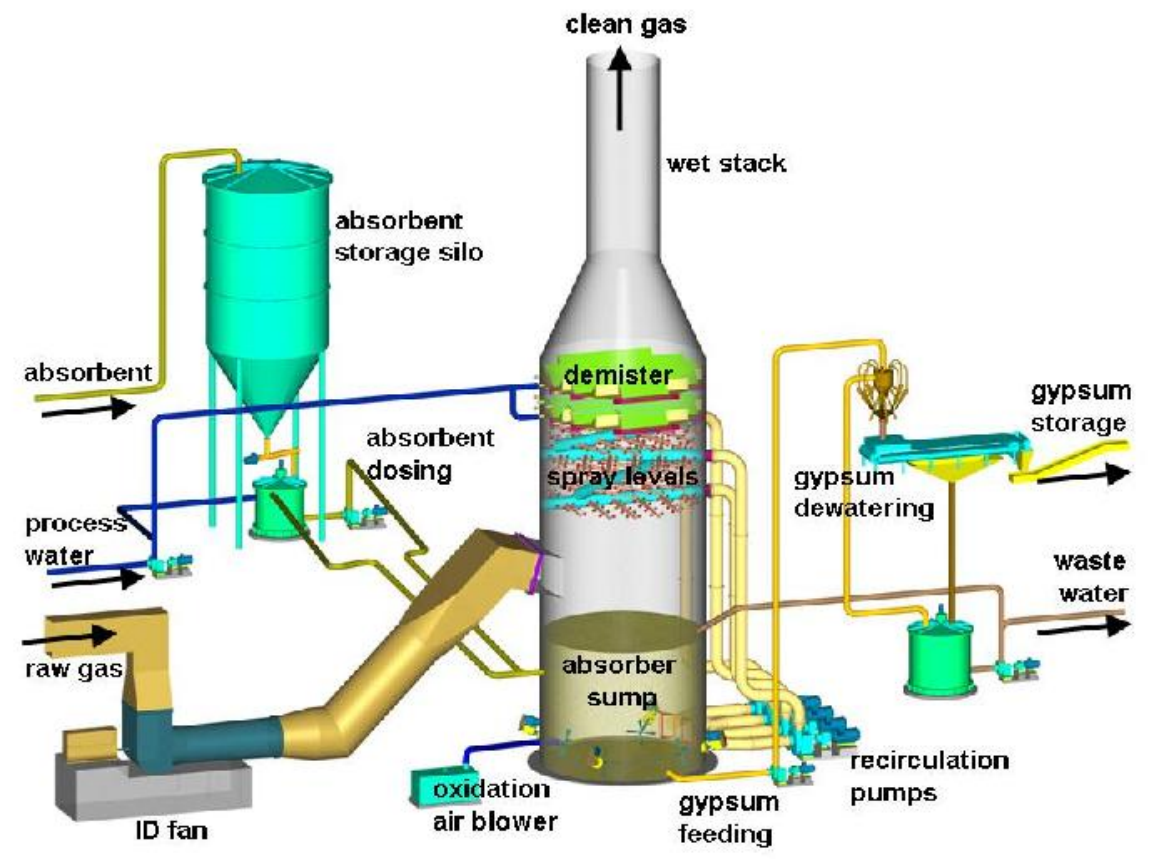

Fig. 1. Wet flue gas desulfurization Source: [12]

Wet flue gas desulfurization has two main disadvantages. The intensive wetting of polluted air causes subsequent costs, which will result from the need to use appropriate equipment to remove water. The second disadvantage is the reheating of the exhaust gases, then may be purification from remaining harmful compounds in the electrostatic precipitator.

The factors associated with the increase in costs caused the management to think about replacing the wet method with other methods of flue gas desulfurization. The wet method was invented and developed as the first method of purification of sulphide exhaust. It is currently and gradually being replaced by the other two techniques for economic and hardware reasons.

In short, the dry method of exhaust after-treatment involves feeding a sorbent into the combustion chamber a substance that absorbs harmful sulfur dioxide, thanks to the use of a suitable installation (Fig. 2). This method involves dosing dry sorbents such as:

- limestone with a $\mathrm{CaCO}_{3}$ content above 90\%;

- hydrated lime: $\mathrm{Ca}(\mathrm{OH})_{2}$;

- burnt lime: $\mathrm{CaO}$;

- dolomit $\mathrm{CaCO}_{3}+\mathrm{MgCO}_{3}$.

The sorbent can be dosed into the boiler in three ways:

- directly mixed with coal (e.g. in a mill);

- blown into the combustion chamber around the flame;

- blown into the combustion chamber above the flame (preferred method).

The dry desulphurisation method (also called the direct method) is based on absorption of sulfur by burnt lime $(\mathrm{CaO})$ obtained from ground limestone, hydrated lime or dolomite. After being introduced into the furnace 
chamber, the sorbent decomposes, i.e. decarbonisation or dehydration according to the reactions, where dQ is the heat of reaction [13]:

$$
\begin{gathered}
\mathrm{CaCO}_{3}+\mathrm{dQ}=>\mathrm{CaO}+\mathrm{CO}_{2} \\
\mathrm{Ca}(\mathrm{OH})_{2}+\mathrm{dQ}=>\mathrm{CaO}+\mathrm{H}_{2} \mathrm{O}
\end{gathered}
$$

and then the lime reacts with $\mathrm{SO}_{2}$ according to the reaction [13]:

$$
\begin{gathered}
\mathrm{CaO}+\mathrm{SO}_{2}=>\mathrm{CaSO}_{3}+\mathrm{dQ} \\
\mathrm{CaO}+\mathrm{SO}_{2}+1 / 2 \mathrm{O}_{2}=>\mathrm{CaSO}_{4}+\mathrm{dQ}
\end{gathered}
$$

Dehydration occurs at temperatures above $400^{\circ} \mathrm{C}$, and decarbonation above $750^{\circ} \mathrm{C}$. Previous experience shows that the introduction of limestone powder to the furnace chamber should be carried out in the temperature areas of $780-1200{ }^{\circ} \mathrm{C}$ [13]. Summarizing, calcium oxides and limestone are most often used as sorbents. The process takes place after blowing the sulphurising substance into the combustion zone. The desulfurization step occurs only at the specified optimal temperature prevailing inside the chamber of the combustion process.

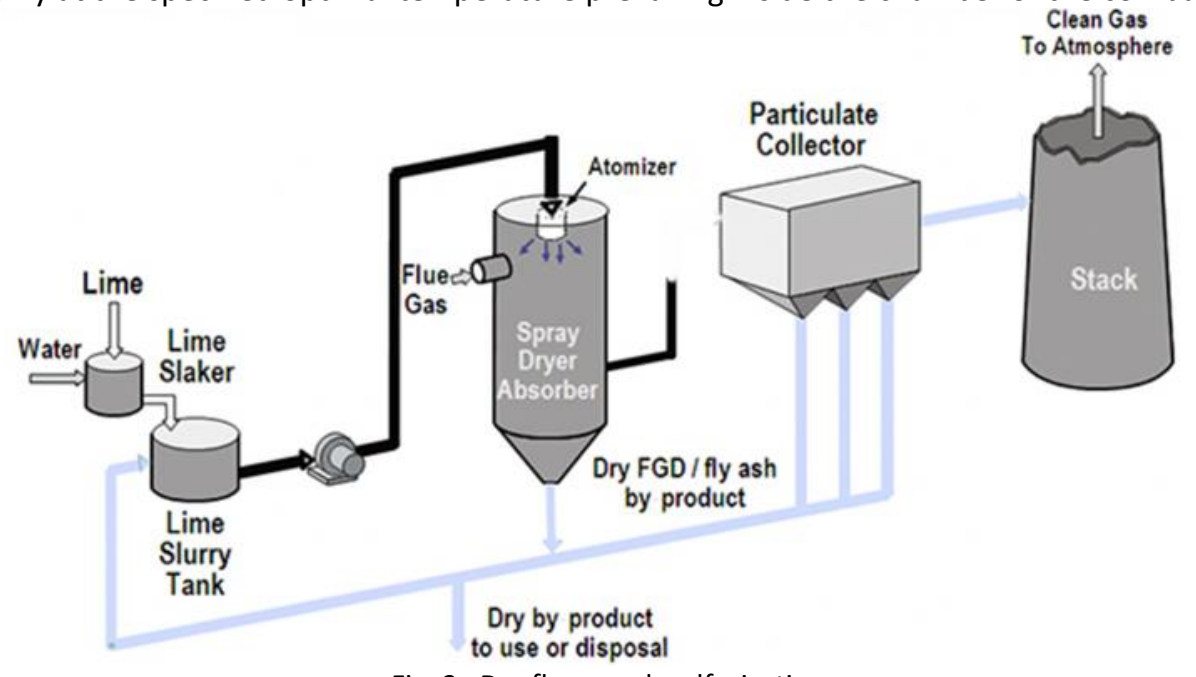

Fig. 2. Dry flue gas desulfurization

Source: [14]

The dry method compared to the other two exhaust purification methods is characterized by a lower desulfurization efficiency. Because of the low implementation costs and the simplicity of construction devices. it is the most often used. The dry method is gradually being replaced by the semi-dry desulfurization technique, due to the lowest efficiency of the purification process in the power industry.

In the introduction, semi-dry desulfurization consists of a stream of very hot flue gas vapor, which contains a sorbent suspension. First step of semi-dry desulfurization process, it consists in dosing the sorbent to the furnace chamber. The following chemical reactions take place [13]:

$$
\begin{gathered}
\mathrm{CaCO}_{3}+\mathrm{dQ}=>\mathrm{CaO}+\mathrm{CO}_{2} \\
\mathrm{Ca}(\mathrm{OH})_{2}+\mathrm{dQ}=>\mathrm{CaO}+\mathrm{H}_{2} \mathrm{O} \\
\mathrm{CaO}+\mathrm{SO}_{2}=>\mathrm{CaSO}_{3}+\mathrm{dQ} \\
\mathrm{CaO}+\mathrm{SO}_{2}+1 / 2 \mathrm{O}_{2}=>\mathrm{CaSO}_{4}+\mathrm{dQ}
\end{gathered}
$$

In the first stage, the process of sulphur dioxide binding proceeds according to mechanisms similar to the dry flue gas desulfurization method, i.e. ground sorbent (limestone with content $\mathrm{CaCO}_{3}$ over $90 \%$, hydrated lime $\mathrm{Ca}(\mathrm{OH})_{2}$, burnt lime $\left.\mathrm{CaO}\right)$ it is dosed to the optimum temperature zone for calcination and binding with sulphur dioxide

into the combustion chamber. The second stage of flue gas desulphurisation is carried out in the exhaust gas sprinkler (absorption washer), which is placed between the exhaust outlet from the boiler and the inlet to the dust collector [13].

$$
\begin{gathered}
\mathrm{CaO}+\mathrm{H}_{2} \mathrm{O}=>\mathrm{Ca}(\mathrm{OH})_{2}+\mathrm{dQ} \\
\mathrm{CaO}+\mathrm{SO}_{2}=>\mathrm{CaSO}_{3}+\mathrm{dQ}
\end{gathered}
$$




$$
\begin{gathered}
\mathrm{Ca}(\mathrm{OH})_{2}+\mathrm{SO}_{2}=>\mathrm{CaSO}_{3}+\mathrm{H}_{2} \mathrm{O}+\mathrm{dQ} \\
\mathrm{Ca}(\mathrm{OH})_{2}+\mathrm{SO}_{2}+\mathrm{H}_{2} \mathrm{O}+1 / 2 \mathrm{O}_{2}=>\mathrm{CaSO}_{4}+2 \mathrm{H}_{2} \mathrm{O}+\mathrm{dQ}
\end{gathered}
$$

Exhaust gases in the sprinkler containing burnt lime $(\mathrm{CaO})$ dust particles on the surfaces from which calcium sulphate $\left(\mathrm{CaSO}_{4}\right)$ was formed or calcium sulfite $\left(\mathrm{CaSO}_{3}\right)$, they are sprinkled with water in an amount ensuring its complete evaporation. The exhaust temperature before the electrostatic precipitator is reduced to safe values for the formation of condensation sulphuric acid $\left(\mathrm{H}_{2} \mathrm{SO}_{4}\right)$, above the dew point.

During the rapid contact of the sorbent with contaminated gas, there are chemical reactions involving the combination of sulfur oxides with an absorbing agent. As a result of the very high temperatures in the interior, the water evaporates at the same time, and the final product of the desulfurization process is dry [13]. The location of semi-dry desulfurization installation in the power station is presented in the figure below (Fig. 3).

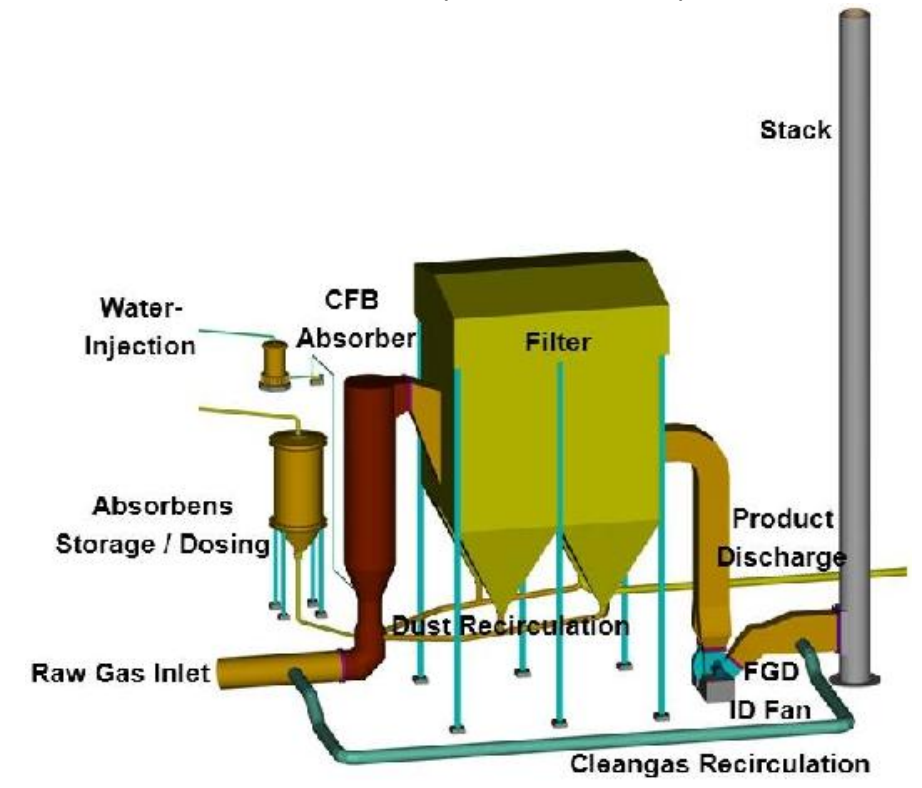

Fig. 3. Semi-dry desulfurization of exhaust gases Source: [15]

The method is characterized by the lower level of water usage during the removal of sulphides while obtaining the final product in a dry form. The final form of the extracted combustion dust in the semi-dry method is rarely used for other purposes. In addition, the usage of the sulphide absorbing agent exceeds the factor price used in the dry desulfurization technique.

\section{Flue gas denitrification method}

This method of selective non-catalytic reduction of nitrogen oxides is called SNCR (Selective Non-Catalytic Reduction) and is based on a high-temperature reaction gaseous ammonia or urea with nitrogen oxides without the catalyst. A ratio of 1 to 2.5 is assumed. The ratio determines the relation of the reactant to the nitrogen oxides depending on the degree of reduction and process assumptions [16].

The reduction process is conditioned not only by reaching the optimal temperature in the limit $850^{\circ} \mathrm{C}-1100^{\circ} \mathrm{C}$, but also proper distribution of the reagent in the exhaust. Too large particles evaporate too slowly, which translates into an increase in the unreacted amount of reagent, but too small particles evaporate too quickly, reacting in this way at the temperatures exceeding the optimum thus lessening the degree of reduction $\mathrm{NO}_{\mathrm{x}}$. The reactions occurring at too high temperatures can cause undesirable production of $\mathrm{NO}_{\mathrm{x}}$ through ammonia oxidation. The process at too low a temperature leads to the additional formation of ammonia. Achieving the appropriate and optimal conditions is essential, and is the most important issue in ensuring the efficiency of the SNCR method. 


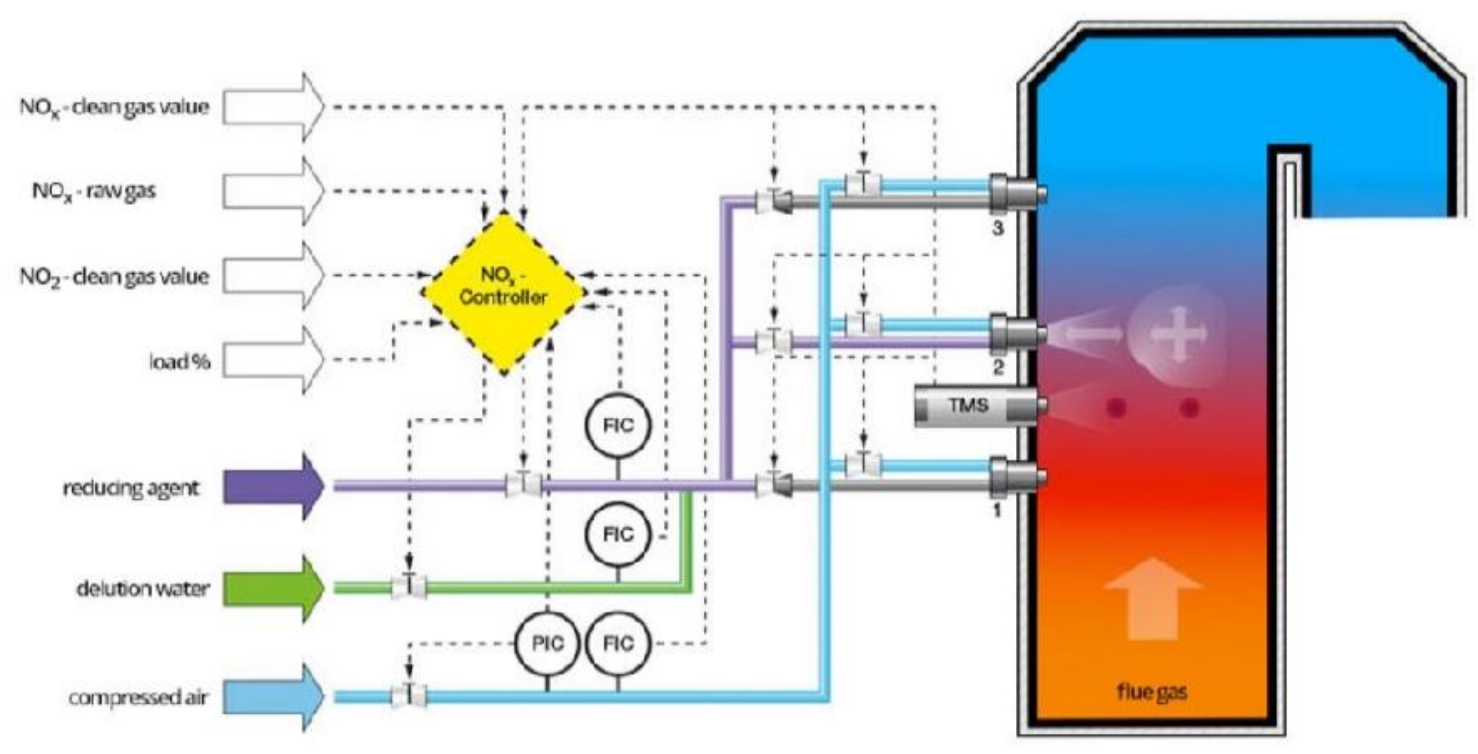

Fig. 4. Scheme of exhaust gas denitrification by the SNCR method Source: [17]

The SNCR installation type of "High Dust" is designed to work in a dusty and sulphated environment on the exhaust route directly behind the boiler and in front of the electrostatic precipitator. For this reason, it interferes with the existing systems of exhaust channels to a large extent, on operating parameters, and investment requirements for pressure systems of water heaters or steam.

\section{Exhaust gas dedusting}

Besides installation of the fuel combustion process in power units, there are dust removal devices from the exhaust. The first studies and patents related to electrostatic precipitators date back to the beginning of the 20th century. Effective equipment development has existed since the 1970s, under the influence of stricter standards in air cleanliness. New construction solutions appeared and the theory of electrostatic dedusting was better understood [18]. Work in the following decades was associated not only with obtaining a high level of effectiveness of action, but also with a high reliability and availability of these devices.

The electrofilters use the influence of the electrostatic field for solid particles (grains of dust) and liquid (mist drops), which is called an aerosol. The active space of the electrostatic precipitator (ESP) creates a high-voltage electrode system (corona discharge electrodes) and collection electrodes, placed relative to each other at certain intervals [19].

A very high constant voltage with negative polarity (up to $110 \mathrm{kV}$ ) is applied to the corona discharge electrodes. The corona electrodes are separated from the grounded electrofilter chamber and the electrodes collected use a special supporting structure mounted on suspension insulators. Collective electrodes, in turn, are mounted directly onto the elements of the electrostatic precipitator's chamber, thanks to which they have the potential for grounding. Thanks to the high voltage connection, a strong electric field is created between corona discharge electrodes and collection electrodes. Dust particles found in the gas stream flowing through the active space between electrodes are charged by negative ions and obtain a negative potential [20].

The charged solid particles are attracted by the surface of the collecting electrodes, with grounding potential, where they are under the influence of electric field forces. 


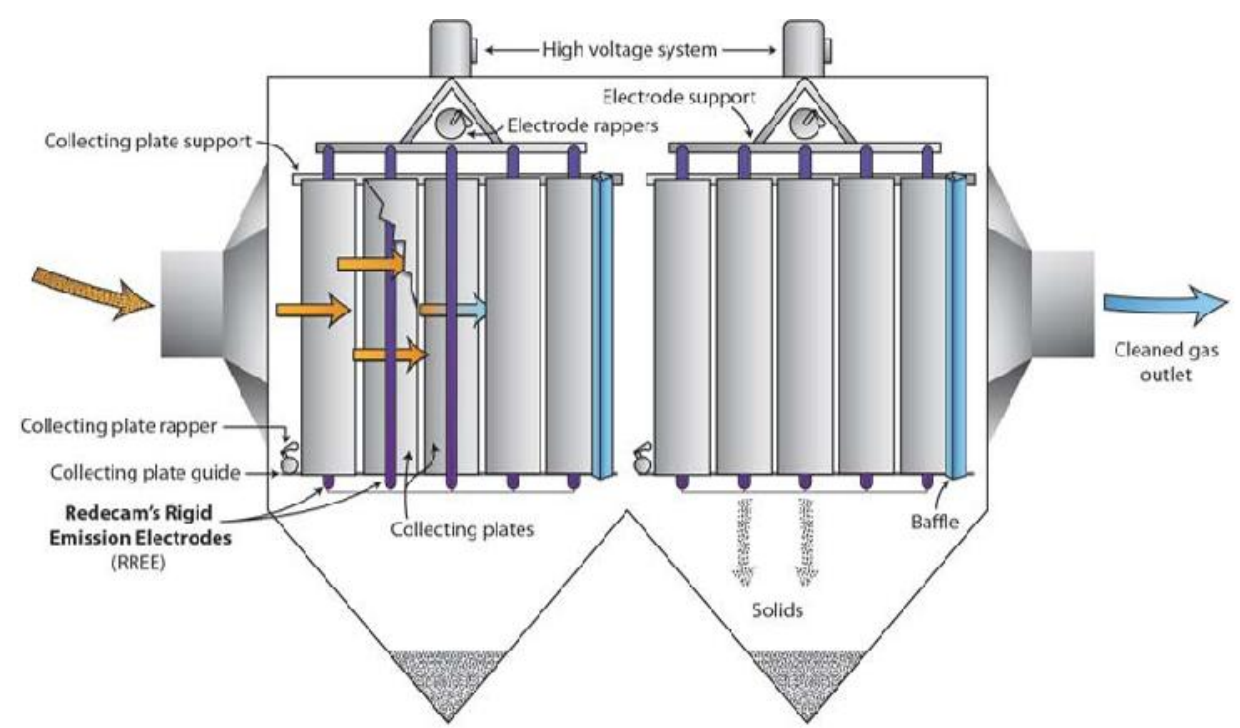

Fig. 5. Principle of ESP operation Source: [21]

The solid particles (dust, droplets of mist) settling on collecting electrodes are removed from them by the cyclic introduction of collecting electrodes into vibrations (dust flushing with collectors rapping devices, providing a sheer force greater than the force of electrostatic attraction). Collective electrodes are shaped in this way to collect the falling ash which was not captured again by the gas stream. Thanks to the appropriate shape of the electrodes and a special membrane located in the dust collecting hoppers, secondary dust entrainment is minimized and the efficiency of electrostatic precipitator removal is improved [22].

A small amount of dust also accumulates on the surface of the corona electrodes, therefore the corona electrodes are also cleaned, according to the same principle as collecting electrodes. As a result of the vibrations, the solid particles accumulated on the electrodes come under the influence of gravity to the dust collecting hoppers located at the bottom of the electrostatic precipitator. From the hoppers the is dust is collected continuously via an independent dust collection system.

\section{The future of power units}

No machine likes sudden load changes, it will only tolerate it or not. The carbon blocks have the right number of starts (and exceeding the permissible parameters, that happen in such states) and sooner or later material problems occur. Cracks will appear followed by failures of greater or lesser intensity.

In a publication available from the International Energy Agency (IEA), important recommendations concerning the modernization of the Polish energy sector are included. The document shows that many coal-fired power plants need to be replaced, which is a result of the long term use of the currently operating facilities [23]. Also in the IEA report, there are recommendations for Poland to take all actions into account for the impact on the protection of the environment and the impact of climate changes. To this end, the Polish government should develop a long-term strategy on climate policy for the coming years.

Furthermore, climate policy should include specific tasks aimed at reducing the emission of harmful chemical compounds, the problem that affects mainly the impact of $\mathrm{CO}_{2}$ on the natural environment (the greenhouse effect) and meeting strict standards which concern the emission of pollutants by large industrial facilities and executes the combustion process in a given region or province.

In addition to tips and recommendations for improving the energy sector, the IEA report also noted Poland's efforts. Energy security and energy efficiency were improved. The energy sector is facing serious demands which include: the implementation of the energy policy assumptions for the years beyond 2025 and the development of technological solutions maintaining the development prospects. Several companies are launching an initiative to transform the Polish power industry. 
The idea of "Duoblock" was developed by the Institute of Power Engineering, Silesian University of Technology in Gliwice, Energoprojekt - Katowice, TAURON and RAFAKO S.A in Katowice. The solution implemented by the above-mentioned companies perfectly fits in with the requirements contained in the BAT (Best Available Techniques) reference document and in the IEA (the International Energy Agency) report. The concept accurately takes into account the assumptions regarding the modernisation of current energy facilities. The main goal is to increase the fitness index and reduce the total emission of pollutants from the fuel combustion process, i.e. sulfur oxides, nitrogen oxides, dust and $\mathrm{CO}_{2}$ [24-25].

The "Duoblocks" project will start the changes, which must be introduced in the Polish power industry, in order to keep up with the changing standards related to environmental protection. In addition, the concept will provide the opportunity to introduce new installations to protect the environment from the emission of harmful chemical compounds, which is a by-product of the combustion of conventional fuels. The idea is generally to replace the currently working two power units with $200 \mathrm{MW}$ power - a new supercritical system.

The new solution will consist of two boilers, which will feed one class turbine 500 [25]. In addition, the project will ensure that power boilers can be fired with different fuels. The concept of "Duoblocks" will make it possible to extend the possibilities of conventional energy and will show the new potential of fossilized raw materials. In addition, the solution will improve the efficiency and the flexibility of the operation of objects from the area of the so-called traditional energy, including a coal-fired plant or biomass. Thus. It will give traditional solutions to compete with the growing RES (Renewable Energy Sources) area. Renewable energy sources have many advantages. However, the key drawback is the unpredictability of objects. The operation of RES installations mainly depends on the atmospheric conditions. Therefore, traditional solutions should also be modernised to guarantee constant access to electricity.

"Duoblocks" these are two boilers working on one turbine. The increasing importance of ecology and the requirements related to the flexibility of new blocks cause that "Duoblocks" are a solution willingly used in various parts of the world. The list of selected units is presented in the table below (Table 2.).

Table 2. Selected power plants equipped with energy "Duoblocks"

\begin{tabular}{|l|l|l|}
\hline \multirow{2}{*}{ The name of the source } & Installed power [MW] \\
\cline { 2 - 3 } & Boiler & Turbine \\
\hline Barbers Point (USA) & $2 \times 90$ & 180 \\
\hline Cedar Bay (USA) & $3 \times 90$ & 250 \\
\hline Eesti (Estonia) & $2 \times 108$ & 216 \\
\hline Balti (Estonia) & $2 \times 108$ & 216 \\
\hline Campha (Wietnam) & $4 \times 150$ & $2 \times 300$ \\
\hline CLECO (USA) & $2 \times 330$ & 660 \\
\hline Sandow (USA) & $2 \times 300$ & 600 \\
\hline Dominion (USA) & $2 \times 334$ & 660 \\
\hline Samcheok (Korea Płd.) & $4 \times 550$ & $2 \times 1100$ \\
\hline
\end{tabular}

Source: [26]

The solution with two boilers operating on one turbine has greater regulatory possibilities than monoblocks. Assuming that each single boiler has a technical minimum of $40 \%$ its rated power, a total minimum "Duoblocks" is obtained at $20 \%$ of the rated power. This allows you to work with the use of primary fuel, with a load of $18 \div 20 \%$ of the rated power of the duoblock, while maintaining the ability to rapidly increase power [26]. This is important especially in situations related to large fluctuations of energy demand and when it is necessary to quickly respond to a change in the system strain related to the work of unstable renewable energy sources.

The Polish power industry is currently mainly based on the combustion of hard coal and lignite. In the near future, the Polish energy policy will await the cyclical introduction of changes directed towards increasing the use of other fuels in the production of electricity. Gas, renewable sources or nuclear power will gradually replace coal. However, with a large share of renewable energy, which is characterized by instability, it should keep a very large amount of power in conventional power plants in reserve. 
The idea of "Duoblocks" will give the opportunity to implement improvements and modernise the existing energy infrastructure, which is now largely obsolete. Activities carried out in the conventional energy area will have to address compliance with strict standards and the assumptions created by the European Union. Requirements for monitoring the level of pollutant emissions in the industrial sector are set out in the BAT (Best Available Techniques) document. In addition, current installations found in traditional energy will have to meet certain conditions regarding the optimisation of technical parameters, which will eventually lead to the increased efficiency of power installations.

\section{Summary and conclusions}

The development of Polish energy mainly depends on the assumptions introduced by the European Union, including updates of applicable standards, regulations and ordinances, concerning the reduction of emission of dust removal (PM 10 and PM 2.5) and gas pollutants into the natural environment. Activities relating to the modernizations of methods and installations in the field of environmental protection were initiated by the Polish energy sector in the last decade of the twentieth century.

Modernizations at the turn of the year were aimed at a regular introduction installations for nitrogen removal, desulfurisation and dust removal. Concepts created in the present are going further in the direction of the improvement of existing energy facilities. The activities carried out are aimed at implementing solutions which will enable the fulfillment of the imposed environmental laws and standards. In addition, the activities carried out will contribute to increasing the opportunities for traditional solutions to compete in the coming years with the constantly developing area of renewable energy sources.

The Polish energy mix is mainly based on the combustion of hard coal and lignite. "Duoblocks" can expand the possibilities of conventional energy. They allow to improve the efficiency and flexibility above all of conventional energy, including coal and biomass facilities. They are focused on traditional, conventional solutions but in such a way that they can compete with other energy sources, mainly such as renewable energy obtained from windmills or solar panels, which with all the advantages have one drawback, renewable energy sources are unpredictable because they depend on the whims of the weather.

\section{References}

[1] Pawlik M., Zaawansowane technologicznie bloki energetyczne - Nowe wyzwania, Energetyka, sierpień 2013, pp. 595-596.

[2] Action Plan for Energy Efficiency, Realising the Potential, Brussels, 19-10-2006 COM (2006) 545 final.

[3] Zaporowski B., Technologie wytwarzania energii elektrycznej dla polskiej elektroenergetyki, Polityka Energetyczna - Energy Policy Journal, v. 18, 2015, pp. 29-44.

[4] Green Paper, A European Strategy for Sustainable, Competitive and Secure Energy, Brussels, 8.3.2006, pp. 17-18.

[5] Directive 2010/75/EU of the European Parliament and of the Council of 24 November 2010 on industrial emissions (integrated pollution prevention and control) (Recast), pp. 1-2.

[6] Minister for the Environment in Poland, Regulation of the Minister for the Environment of 30th October 2014 on the requirements for the measurement of emission volumes and the amount of water abstracted, Official Gazette, 2014/1542, 2014, pp. 1-3.

[7] Minister for the Environment in Poland, Regulation of the Minister for the Environment of 4th November 2014 on the emission standards for certain types of installation, fuel combustion plants and waste incineration or co-incineration facilities, Official Gazette, 2014/1546, 2014, pp. 19-25.

[8] Brzezińska A., IT systems supporting the Polish energy sector in proecological activities, Publisher Energy Market (Rynek Energii), Nr 2 (135), 2018, pp. 39.

[9] Chmielniak T., Rusin A., Łukowicz H., Modernizacja i rewitalizacja istniejących bloków węglowych ważnym warunkiem stabilności sektora wytwarzania elektryczności, Polityka Energetyczna - Energy Policy Journal, v. 19, 2016, pp. 49-59.

[10] Szczepańska J., Emission of major pollutants, The air, vol. 3, www.wios.lodz.pl/files/docs/r11xiiixpo wietrze.pdf, available: 05.07.2018, pp. 106.

[11] Myśliński A., Metody odsiarczania gazów odlotowych, www.chem.uw.edu.pl/people/AMyslinski/JS/wyk_ 03.ppt, available: 25.10 .2018 . 
[12] Hamon, Wet flue gas desulfurization with lime/limestone slurry, https://www.hamon.com/solutions/acidgas-removal/wet-flue-gas-desulfurization-with-lime-limestone-slurry/, available: 08.10.2018.

[13] Wardak P., The investment process and NOx and SOx Reduction Methods on the example of selected Polish power facilities, Modern Power Industry in Central and Eastern Europe, 2015, pp. 4-5.

[14] Carmeusena, Dry scrubbing, http://www.carmeusena.com/markets/flue-gas-treatment/dry-scrubbing, available: 08.03.2019.

[15] Hamon, Semi-dry flue gas desulfurization, https://www.hamon.com/solutions/acid-gas-removal/desox-6/, available: 08.10.2018.

[16] Kordyaczny H., Śpiewak I., Modern flue gas denitrificaton technologies for the power industry and other industrial branches vs changing environmental regulations, Energetyka, 2016, pp. 723-727

[17] ERC Technik, SNCR plants, http://www.erc-online.de/en/erc-technik/plants/denox-plants/sncr/, available: 08.10.2018.

[18] Biedrzycka A., Elektrofiltry w energetyce. Do wymiany lub modernizacji, materiał pokonferencyjny "Elektrofiltry 2004”, http://www.gigawat.net.pl/archiwum/article/articleprint/407/-1/46/index.html, 2004, available: 18.09.2018.

[19] Shah K. P., Construction, Working, Operation and Maintenance of Electrostatic Precipitators (ESPs), 2017, pp. 5-11.

[20] Suleman M., Saleem M., Siebenhofer M., Characterization of brush type discharge electrodes and the impact of enhanced corona discharge on the operation of electrostatic precipitators, Journal of Electrostatics, v. 70, 2012, pp. 144-148.

[21] Redecam Group, Electrostatic Precipitators, http://www.redecam.com/electrostatic-precipitators/, available: 18.09.2018.

[22] Tracz P., Biały L., Wacławiak K., Directions of improvements of modern electrostatic precipitators, Archives of Waste Management and Environmental Protection, 18, 2016, pp. 2-6.

[23] IEA, Energy Policies of IEA Countries, Polish 2016 Review, Executive Summary Polish, https://www.iea.org/publications/freepublications/publication/EnergyPoliciesofIEACountriesPolish2016R eviewExecutiveSummaryPolish.pdf, available:03.10.2018

[24] ENERGOPROJEKT - KATOWICE S.A., DUOBLOK 500 jako rozwiązanie dla rekonstrukcji bloków 200 MW, http://www.igeos.pl/images/files/2016/1717/MZmija.pdf, available 09.09.2018.

[25] Best Available Techniques (BAT) Reference Document for Large Combustion Plants Industrial Emissions Directive 2010/75/EU (Integrated Pollution Prevention and Control) Joint Research Centre, Institute for Prospective Technological Studies, Sustainable Production and Consumption Unit, European IPPC Bureau, Final Draft, 2016.

[26] Paska J., Pawlak K., Duobloki energetyczne jako potencjalny element strategii rewitalizacji sektora wytwarzania energii elektrycznej w Polsce, Rynek Energii, 2014, pp. 6-7. 